Nevada

Environmental

Restoration

Project

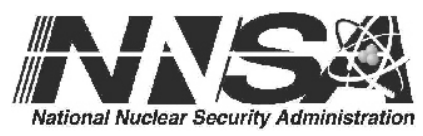

Closure Report for

Corrective Action Unit 139:

Waste Disposal Sites,

Nevada Test Site, Nevada

Controlled Copy No.:

Revision: 0

July 2009

Environmental Restoration

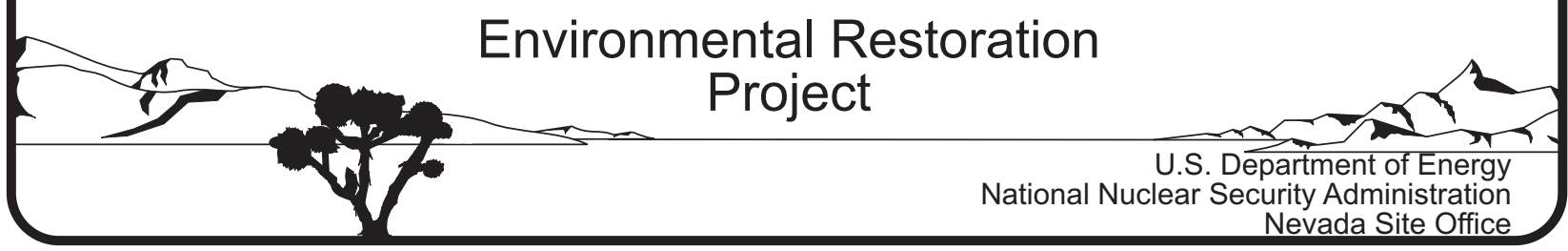




\section{DISCLAIMER}

Reference herein to any specific commercial product, process, or service by trade name, trademark, manufacturer, or otherwise, does not necessarily constitute or imply its endorsement, recommendation, or favoring by the United States Government or any agency thereof.

This report has been reproduced directly from the best available copy.

Available for sale to the public from:

U.S. Department of Commerce

National Technical Information Service

5285 Port Royal Road

Springfield, VA 22161-0002

Telephone: (800) 553-6847

Fax: (703) 605-6900

E-mail: orders@ntis.gov

Online ordering: http://www.ntis.gov/help/ordermethods.aspx

Available electronically at http://www.osti.gov/bridge.

Available for a processing fee to the U.S. Department of Energy and its contractors, in paper, from:

U.S. Department of Energy

Office of Scientific and Technical Information

P.O. Box 62

Oak Ridge, TN 37831-0062

Telephone: (865) 576-8401

Fax: (865) 576-5728

E-mail: reports@adonis.osti.gov 


\title{
CLOSURE REPORT FOR CORRECTIVE ACTION UNIT 139: WASTE DISPOSAL SITES, NEVADA TEST SITE, NEVADA
}

\author{
U.S. Department of Energy \\ National Nuclear Security Administration \\ Nevada Site Office \\ Las Vegas, Nevada
}

Controlled Copy No.

Revision: 0

July 2009 
THIS PAGE INTENTIONALLY LEFT BLANK 


\section{CLOSURE REPORT FOR CORRECTIVE ACTION UNIT 139: \\ WASTE DISPOSAL SITES, NEVADA TEST SITE, NEVADA}

\footnotetext{
Approved By: /s/: Kevin Cabble

Date: $7-22-0 ?$

Kevin J. Cabble,

Federal Sub-Project Director

Industrial Sites Sub-Project

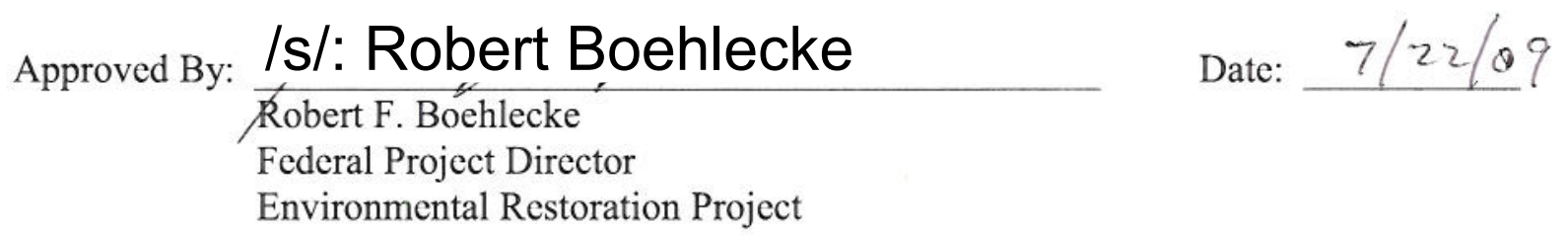


THIS PAGE INTENTIONALLY LEFT BLANK 


\section{TABLE OF CONTENTS}

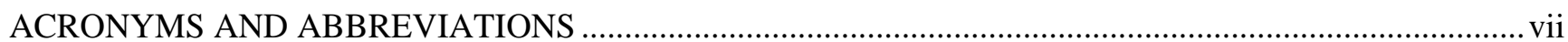

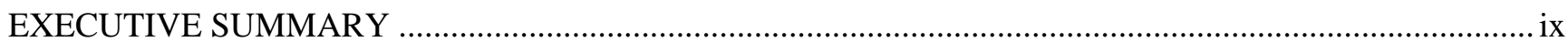

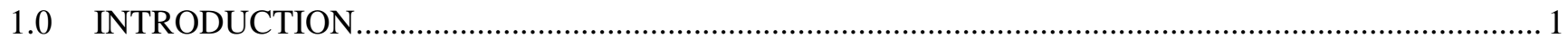

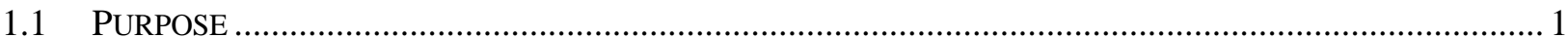

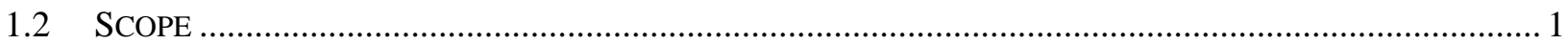

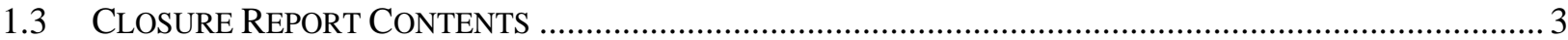

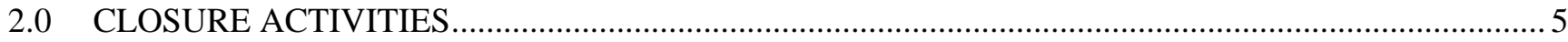

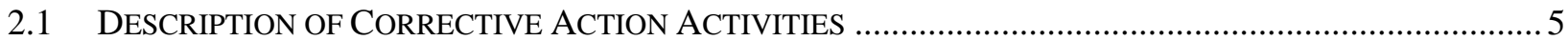

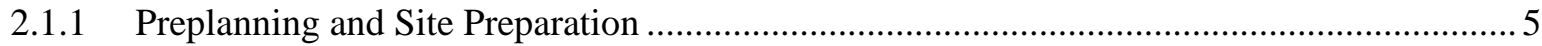

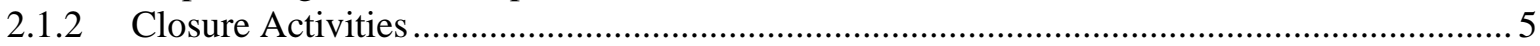

2.1.2.1 Corrective Action Site 03-35-01, Burn Pit ................................................................ 5

2.1.2.2 Corrective Action Site 04-08-02, Waste Disposal Site ............................................. 5

2.1.2.3 Corrective Action Site 04-99-01, Contaminated Surface Debris ............................. 7

2.1.2.4 Corrective Action Site 06-19-02, Waste Disposal Site/Burn Pit.............................. 7

2.1.2.5 Corrective Action Site 06-19-03, Waste Disposal Trenches .................................... 7

2.1.2.6 Corrective Action Site 09-23-01, Area 9 Gravel Gertie.......................................... 7

2.1.2.7 Corrective Action Site 09-34-01, Underground Detection Station .......................... 9

2.2 DEVIATIONS FROM THE CORRECTIVE ACTION PLAN AS APPROVED....................................................

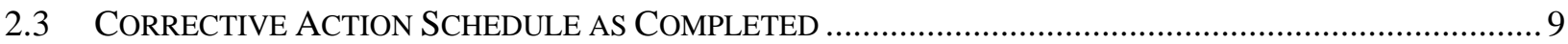

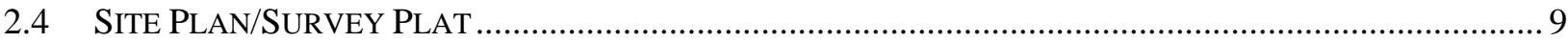

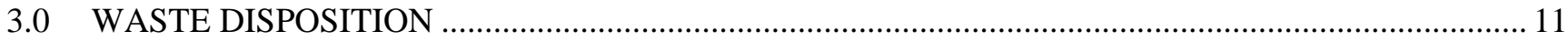

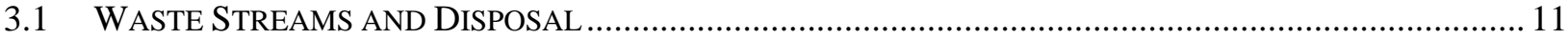

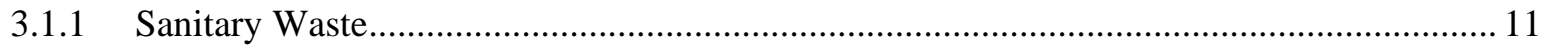

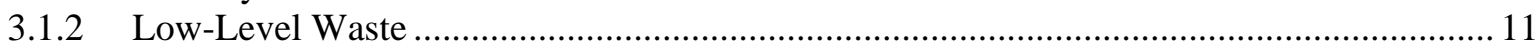

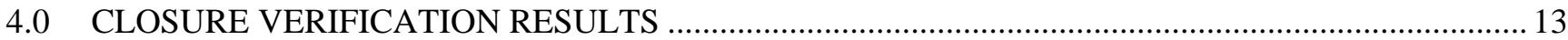

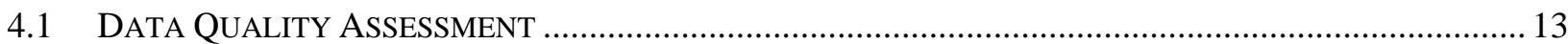

4.1.1 Quality Assurance and Quality Control Procedures...................................................... 13

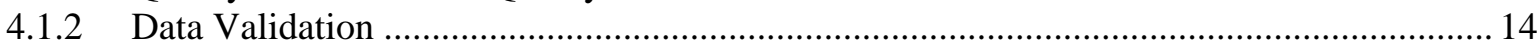

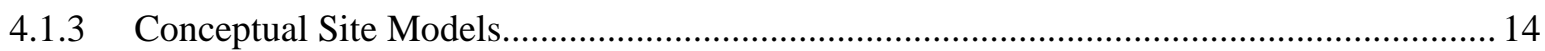

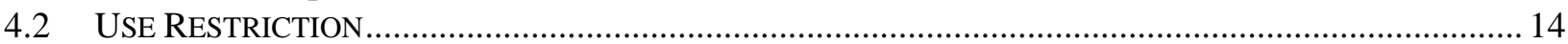

4.2.1 Corrective Action Site 04-08-02, Waste Disposal Site ...................................................... 14

4.2.2 Corrective Action Site 06-19-03, Waste Disposal Trenches ............................................... 15

4.2.3 Corrective Action Site 09-23-01, Area 9 Gravel Gertie.................................................... 15

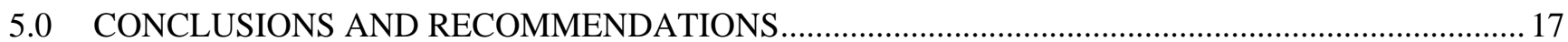

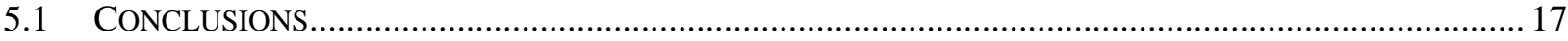

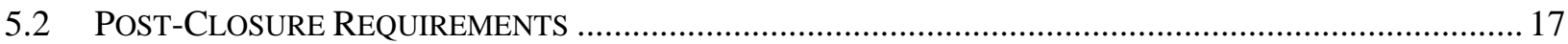

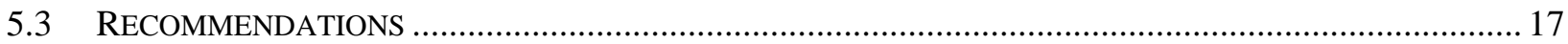

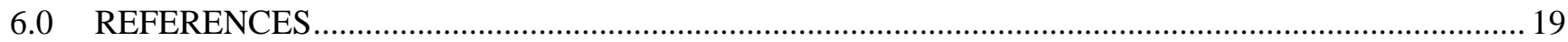

LIBRARY DISTRIBUTION LIST 


\section{TABLE OF CONTENTS (continued)}

\section{LIST OF FIGURES}

Figure 1. Corrective Action Unit 139 Site Location Map .......................................................2

Figure 2. Verification SAmple Locations at Corrective Action Site 03-35-01, Burn Pit.........6

Figure 3. Verification SAMPle LoCATIONS AT Corrective ACTION Site 04-99-01, CONTAMINATED SURFACE DEBRIS

\section{LIST OF TABLES}

TABle 1. Summary of Corrective Action Unit 139 Closure Activities..................................... X

Table 2. Corrective Action Unit 139 Closure Activities Schedule .......................................9

TABle 3. Verification SAMPle Results For CoRrective Action Site 03-35-01 ............................13

TABle 4. VerificAtion SAMPle Results FOR CORRECTIVE ACTION Site 04-99-01 ..........................13

\section{APPENDICES}

Appendix A. DATa Quality OBJectives

APPENDIX B. SAMPLE ANALYTICAL RESUlTS

APPENDIX C. WASTE DISPOSITION DOCUMENTATION

APPENDIX D. USE RESTRICTION DOCUMENTATION

APPENDIX E. Site ClOSURE PHOTOGRAPHS

APPENDIX F. NEVADA DIVISION OF ENVIRONMENTAL PROTECTION COMMENT RESPONSE FORM 


\section{ACRONYMS AND ABBREVIATIONS}

BMP best management practice

CADD Corrective Action Decision Document

CAIP Corrective Action Investigation Plan

CAP Corrective Action Plan

CAS Corrective Action Site

CAU Corrective Action Unit

COC contaminant of concern

CR Closure Report

CSM conceptual site model

EPA U.S. Environmental Protection Agency

FAL final action level

FIMS Facilities Information Management System

FFACO Federal Facility Agreement and Consent Order

LLW low-level waste

NCRP National Council on Radiation Protection

NDEP Nevada Division of Environmental Protection

NNSA/NSO U.S. Department of Energy, National Nuclear Security Administration Nevada Site Office

NNSA/NV U.S. Department of Energy, National Nuclear Security Administration Nevada Operations Office

NTS Nevada Test Site

PAL preliminary action level

$\mathrm{pCi} / \mathrm{g} \quad$ picocurie(s) per gram

$\mathrm{Pu} \quad$ plutonium

QA quality assurance

QAPP Industrial Sites Quality Assurance Project Plan

QC quality control

UR use restriction

$\mathrm{yd}^{3} \quad$ cubic yard(s) 
CAU 139 Closure Report

Section: Acronyms and Abbreviations

Revision: 0

Date: July 2009

\section{THIS PAGE INTENTIONALLY LEFT BLANK}




\section{EXECUTIVE SUMMARY}

Corrective Action Unit (CAU) 139 is identified in the Federal Facility Agreement and Consent Order (FFACO) as "Waste Disposal Sites" and consists of the following seven Corrective Action Sites (CASs), located in Areas 3, 4, 6, and 9 of the Nevada Test Site:

- CAS 03-35-01, Burn Pit

- CAS 04-08-02, Waste Disposal Site

- CAS 04-99-01, Contaminated Surface Debris

- CAS 06-19-02, Waste Disposal Site/Burn Pit

- CAS 06-19-03, Waste Disposal Trenches

- CAS 09-23-01, Area 9 Gravel Gertie

- CAS 09-34-01, Underground Detection Station

Closure activities were conducted from December 2008 to April 2009 according to the FFACO (1996, as amended February 2008) and the Corrective Action Plan for CAU 139

(U.S. Department of Energy, National Nuclear Security Administration Nevada Site Office, 2007b). The corrective action alternatives included No Further Action, Clean Closure, and Closure in Place with Administrative Controls. Closure activities are summarized in Table 1. 
TAble 1. Summary Of CoRrective ACtion Unit 139 Closure Activities

\begin{tabular}{|c|c|c|c|c|}
\hline CAS & CAS NAME & CLOSURE METHOD & COC & Closure ACtivities \\
\hline 03-35-01 & Burn Pit & Clean Closure & Pu-239 & $\begin{array}{l}\text { - Contaminated soil and debris were removed at two locations. } \\
\text { - Verification samples were collected. } \\
\text { - As a BMP, debris was excavated from locations of geophysical } \\
\text { anomalies and surface debris was removed. }\end{array}$ \\
\hline 04-08-02 & Waste Disposal Site & No Further Action & None & - As a BMP, an administrative UR was implemented. \\
\hline 04-99-01 & $\begin{array}{l}\text { Contaminated } \\
\text { Surface Debris }\end{array}$ & Clean Closure & Pu-239 & $\begin{array}{l}\text { - Contaminated soil and debris were removed at one location. } \\
\text { - Verification samples were collected. } \\
\text { - As a BMP, debris was excavated from locations of geophysical } \\
\text { anomalies and surface debris was removed. }\end{array}$ \\
\hline 06-19-02 & $\begin{array}{c}\text { Waste Disposal } \\
\text { Site/Burn Pit }\end{array}$ & No Further Action & None & None \\
\hline 06-19-03 & $\begin{array}{c}\text { Waste Disposal } \\
\text { Trenches }\end{array}$ & $\begin{array}{l}\text { Closure in Place with } \\
\text { Administrative } \\
\text { Controls }\end{array}$ & Assumed $^{\mathrm{A}}$ & $\begin{array}{l}\text { - A native soil cover was constructed. } \\
\text { - As a BMP, the water line was relocated outside the cover boundary. } \\
\text { - Monuments and UR warning signs were installed. } \\
\text { - A UR was implemented. }\end{array}$ \\
\hline 09-23-01 & $\begin{array}{c}\text { Area } 9 \text { Gravel } \\
\text { Gertie }\end{array}$ & $\begin{array}{l}\text { Closure in Place with } \\
\text { Administrative } \\
\text { Controls }\end{array}$ & Assumed $^{\mathrm{B}}$ & - A UR was implemented. \\
\hline 09-34-01 & $\begin{array}{c}\text { Underground } \\
\text { Detection Station }\end{array}$ & No Further Action & None & None \\
\hline
\end{tabular}

BMP: best management practice

CAS: Corrective Action Site

COC: contaminant of concern

Pu: plutonium

UR: use restriction

A The landfill contents could not be sufficiently characterized to preclude the potential presence of COCs; therefore, a conservative assumption was made that COCs exist within the landfill.

${ }^{\mathrm{B}}$ No environmental samples were collected at this CAS; however, based on process knowledge and the investigation of a similar CAS, it is assumed to contain uranium. 


\subsection{INTRODUCTION}

This Closure Report (CR) documents closure activities for Corrective Action Unit (CAU) 139, "Waste Disposal Sites," according to the Federal Facility Agreement and Consent Order (FFACO) (1996, as amended February 2008) and the Corrective Action Plan (CAP) for CAU 139 (U.S. Department of Energy, National Nuclear Security Administration Nevada Site Office [NNSA/NSO], 2007b). CAU 139 consists of the following seven Corrective Action Sites (CASs), located in Areas 3, 4, 6, and 9 of the Nevada Test Site (NTS) (Figure 1):

- CAS 03-35-01, Burn Pit

- CAS 04-08-02, Waste Disposal Site

- CAS 04-99-01, Contaminated Surface Debris

- CAS 06-19-02, Waste Disposal Site/Burn Pit

- CAS 06-19-03, Waste Disposal Trenches

- CAS 09-23-01, Area 9 Gravel Gertie

- CAS 09-34-01, Underground Detection Station

\subsection{Purpose}

CAU 139, "Waste Disposal Sites," consists of seven CASs in Areas 3, 4, 6, and 9 of the NTS. The closure alternatives included No Further Action, Clean Closure, and Closure in Place with Administrative Controls. This CR provides a summary of completed closure activities, documentation of waste disposal, and confirmation that remediation goals were met.

\subsection{SCOPE}

The closure strategy for CAU 139 included the following activities:

- At CAS 03-35-01, Burn Pit, approximately 15 cubic yards $\left(\mathrm{yd}^{3}\right)$ of soil and debris contaminated with plutonium (Pu)-239 were removed and disposed as low-level waste (LLW). Samples verified that all contaminated material had been removed, and the excavations were backfilled with clean soil. As a best management practice (BMP), debris was removed from the locations of four subsurface geophysical anomalies and disposed as sanitary waste, and all surface debris was removed and disposed as sanitary waste.

- At CAS 04-08-02, Waste Disposal Site, no further action was required; however, as a BMP, the area was recorded in the Facilities Information Management System (FIMS) database as an administrative use restriction (UR) to protect future workers from exposure to radionuclides should the land use scenario change from that used to calculate the final action levels (FALs). No postings or post-closure monitoring are required.

- At CAS 04-99-01, Contaminated Surface Debris, approximately $4 \mathrm{yd}^{3}$ of soil and debris contaminated with Pu-239 were removed and disposed as LLW. Samples verified that all contaminated material had been removed, and the excavation was backfilled with clean soil. As a BMP, debris was removed from the locations of two subsurface geophysical anomalies and disposed as sanitary waste, and all surface debris was removed and disposed as sanitary waste. 


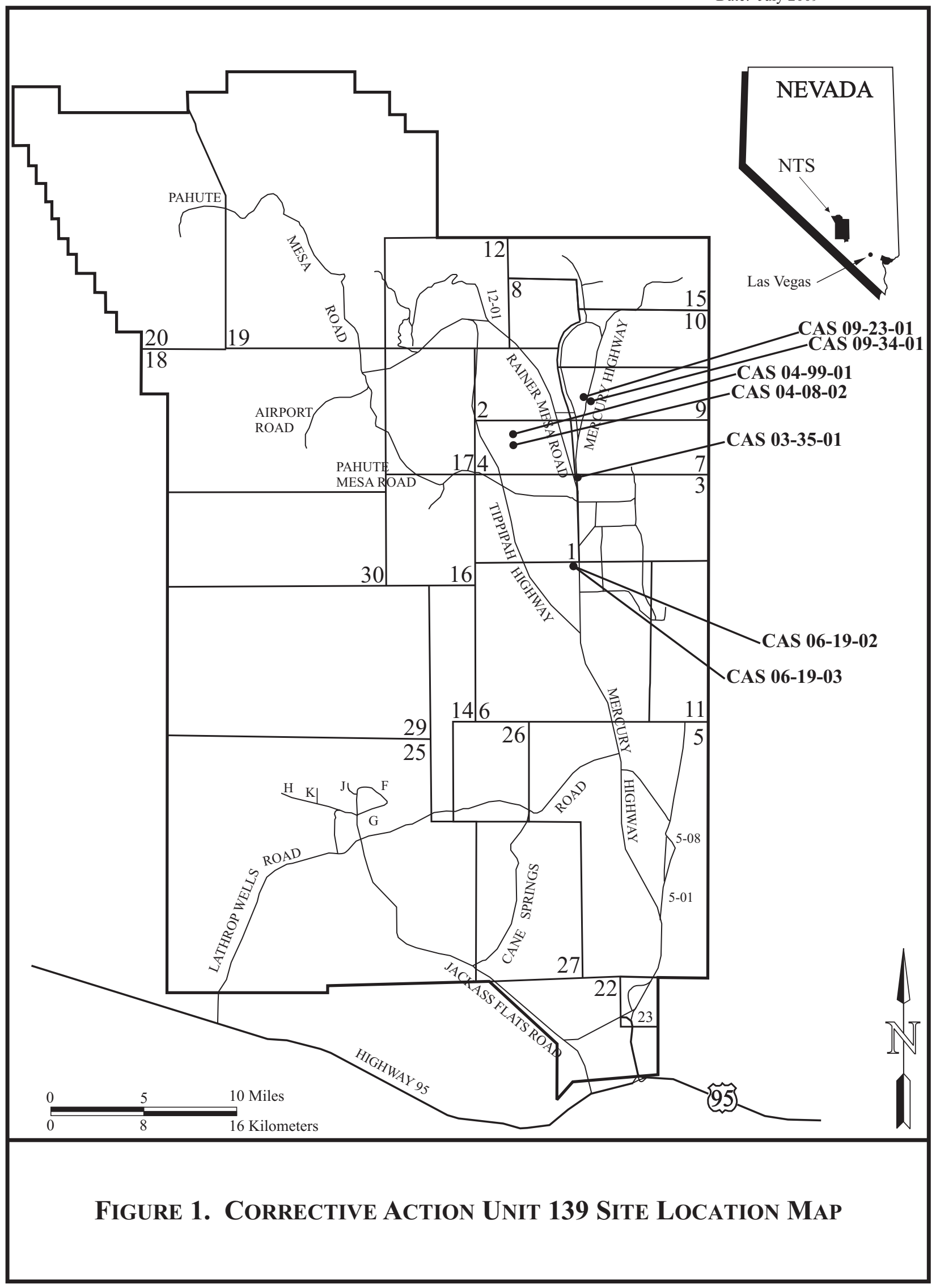


- At CAS 06-19-02, Waste Disposal Site/Burn Pit, no further action was required, and no work was performed.

- At CAS 06-19-03, Waste Disposal Trenches, radioactive and/or hazardous contaminants of concern (COCs) are assumed to be present within the trenches. The site was closed in place with administrative controls. A native soil cover was installed over the waste trenches, monuments and UR warning signs were installed, and a UR was implemented. As a BMP, the water line that ran through the site was diverted to a location outside the cover boundary.

- At CAS 09-23-01, Area 9 Gravel Gertie, uranium is assumed to be present based on process knowledge. The site was closed in place with administrative controls. UR warning signs had been posted during the site characterization phase of the project. A UR was implemented.

- At CAS 09-34-01, Underground Detection Station, no further action was required, and no work was performed. As a BMP, a fence was erected around the entrance during the site characterization phase of the project.

\subsection{Closure Report ConTents}

This CR includes the following sections:

- Section 1.0 - Introduction

- Section 2.0 - Closure Activities

- Section 3.0 - Waste Disposition

- Section 4.0 - Closure Verification Results

- Section 5.0 - Conclusions and Recommendations

- Section 6.0 - References

- Appendix A - Data Quality Objectives

- Appendix B - Sample Analytical Results

- Appendix C - Waste Disposition Documentation

- Appendix D - Use Restriction Documentation

- Appendix E - Site Closure Photographs

- Appendix F - Nevada Division of Environmental Protection Comment Response Form

- Library Distribution List

This report was developed using information and guidance from the following documents:

- Corrective Action Investigation Plan (CAIP) for CAU 139 (NNSA/NSO, 2006)

- Corrective Action Decision Document (CADD) for CAU 139 (NNSA/NSO, 2007a)

- CAP for CAU 139 (NNSA/NSO, 2007b)

- Industrial Sites Quality Assurance Project Plan (QAPP) (U.S. Department of Energy, National Nuclear Security Administration Nevada Operations Office [NNSA/NV], 2002)

Data quality objectives developed for site characterization were presented in Appendix A of the CAIP (NNSA/NSO, 2006) and are included as Appendix A of this report. Conceptual site models (CSMs) were based on process knowledge, historical information, and personnel interviews. The CSMs were confirmed by sample results and verified during closure activities. 
CAU 139 Closure Report

Section: Introduction

Revision: 0

Date: July 2009

THIS PAGE INTENTIONALLY LEFT BLANK 


\subsection{CLOSURE ACTIVITIES}

This section describes the closure activities completed for CAU 139, deviations from the CAP, and the schedule of completed activities.

\subsection{Description of Corrective ACtion Activities}

The following sections describe the closure activities completed for CAU 139.

\subsubsection{Preplanning and Site Preparation}

Prior to closure activities, the following documents were prepared:

- National Environmental Policy Act Checklist

- Site-Specific Health and Safety Plan

- Field Management Plan

- NNSA/NSO Real Estate/Operations Permits

- Work control packages

\subsubsection{Closure Activities}

The following sections detail the closure activities completed at each CAS.

\subsubsection{Corrective Action Site 03-35-01, Burn Pit}

This site consisted of two small burn areas with charred soil and debris and four geophysical anomalies (Figure 2). At the two burn areas, $\mathrm{Pu}-239$ was present at concentrations above the FAL. The site was clean closed. Approximately $15 \mathrm{yd}^{3}$ of contaminated soil and debris were removed and disposed as LLW. Four verification samples and two blind duplicate samples were collected from the excavations and analyzed for $\mathrm{Pu}-238$ and $\mathrm{Pu}-239 / 240$. Pu-238 and $\mathrm{Pu}-239 / 240$ were not present in the verification samples at concentrations above the FALs; therefore, the excavations were backfilled with clean soil. As a BMP, debris was removed from the locations of the four subsurface geophysical anomalies and disposed as sanitary waste, the excavations were backfilled, and all surface debris was removed and disposed as sanitary waste.

\subsubsection{Corrective Action Site 04-08-02, Waste Disposal Site}

This site consists of a previous radioactive debris storage area. No COCs are present at concentrations above FALs; however, cesium-137, europium-152, and europium-154 are present at concentrations above preliminary action levels (PALs) based on the National Council on Radiation Protection (NCRP) Report No. 129 (NCRP, 1999) for construction, commercial, and industrial land-use scenarios scaled to a 25-millirem per year dose constraint. The radionuclides do not exceed FALs calculated using the Residual Radiation Computer Code based on a remote work area scenario (Murphy, 2004) and are therefore not considered COCs. The administrative UR prevents future site activities that would result in an exposure to site workers greater than the remote work area scenario (42 days per year for 25 years). 


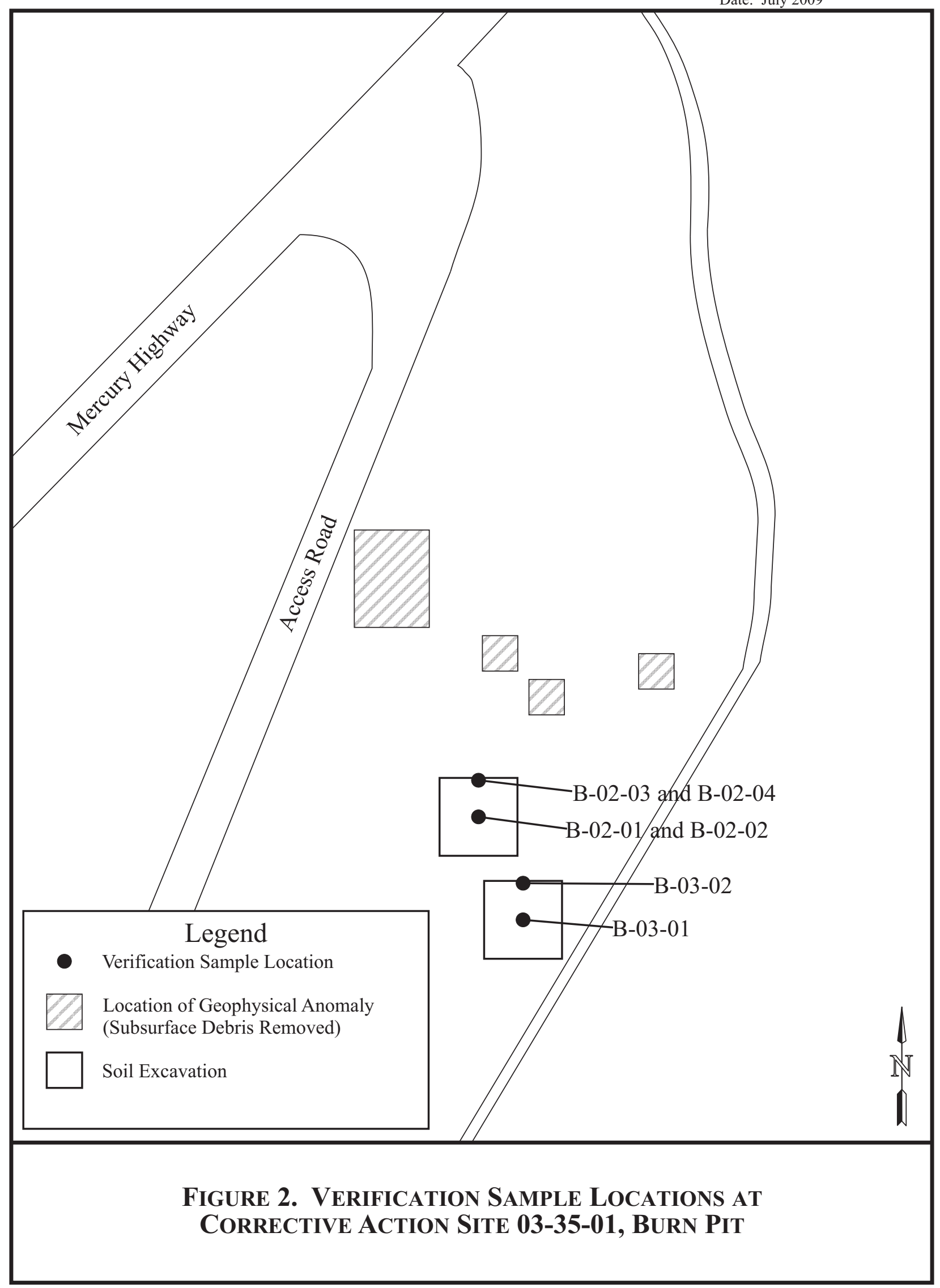


$\mathrm{Pu}-239$ is also present at concentrations above the PAL; however, $\mathrm{Pu}-239$ contamination is attributable to atmospheric tests and will be addressed under the Soils Project. Since Pu-239 contamination is not attributable to CAS 04-08-02, it is not considered a COC. No further action was required; however, as a BMP, the area was recorded in the FIMS database as an administrative UR to protect future workers from exposure to radionuclides should the land use scenario change from that used to calculate the FALs. No postings or post-closure monitoring are required.

\subsubsection{Corrective Action Site 04-99-01, Contaminated Surface Debris}

This site consisted of a former storage area for radioactive debris and two geophysical anomalies (Figure 3). Pu-239 was present at concentrations above the FAL in one location. The site was clean closed. Approximately $4 \mathrm{yd}^{3}$ of contaminated soil and debris were removed and disposed as LLW. Two verification samples and one blind duplicate sample were collected from the excavation and analyzed for Pu-238 and Pu-239/240. Pu-238 and Pu-239/240 were not present in the verification samples at concentrations above the FALs; therefore, the excavation was backfilled with clean soil. As a BMP, debris was removed from the locations of the two subsurface geophysical anomalies and disposed as sanitary waste, the excavations were backfilled, and all surface debris was removed and disposed as sanitary waste.

\subsubsection{Corrective Action Site 06-19-02, Waste Disposal Site/Burn Pit}

This site consists of an area associated with the Area 6 U.S. Environmental Protection Agency (EPA) Farm, a burn pit, and a waste disposal site. No COCs are present at the site; therefore, no further action was required, and no work was performed.

\subsubsection{Corrective Action Site 06-19-03, Waste Disposal Trenches}

This site consists of waste trenches containing the buried remains of Area 6 EPA Farm animals and associated waste. An active water line ran through the trenches from Well 3 to U1a. Radioactive and/or hazardous COCs are assumed to be present in the trenches. The site was closed in place with administrative controls. All surface debris was removed and disposed as sanitary waste, a native soil cover was installed over the waste trenches, monuments and UR warning signs were installed, and a UR was implemented. As a BMP, the water line was diverted to a location outside the cover boundary.

\subsubsection{Corrective Action Site 09-23-01, Area 9 Gravel Gertie}

This site consists of a gravel structure designed to retain radionuclides during a detonation. Uranium is assumed to be present based on process knowledge. The site was closed in place with administrative controls. UR warning signs had been posted during the site characterization phase of the project. A UR was implemented. 


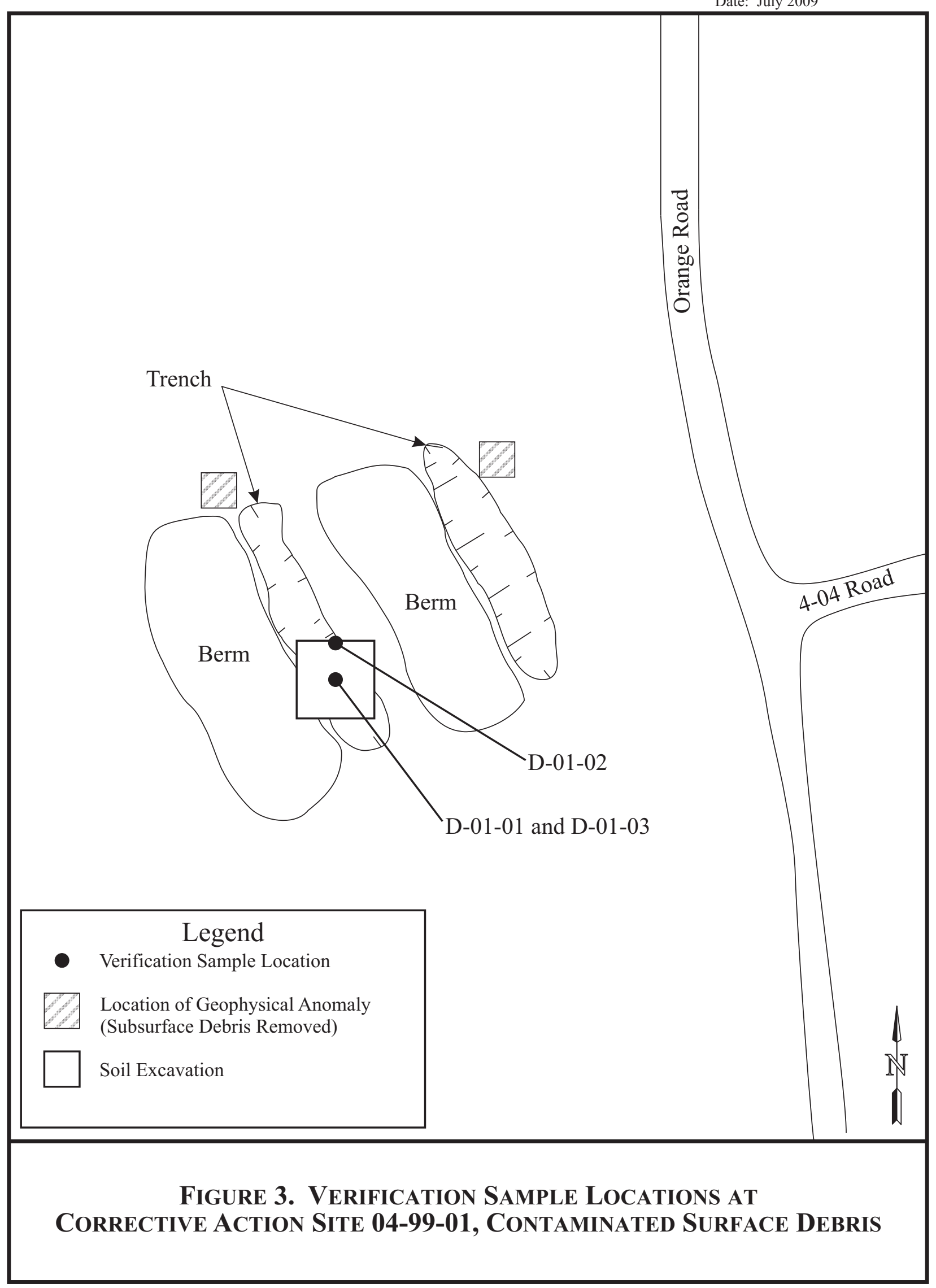




\subsubsection{Corrective Action Site 09-34-01, Underground Detection Station}

This site consists of an underground bunker. No COCs are present at the site. No further action was required; however, as a BMP, a safety fence restricting access to the entrance of the bunker had been installed during the site characterization phase of the project.

\subsection{Deviations from the Corrective Action Plan as Approved}

Deviations from the CAP (NNSA/NSO, 2007b) were not necessary.

\subsection{Corrective ACtion Schedule as Completed}

Closure activities began in December 2008 and were completed in April 2009. Details of the schedule are provided in Table 2.

Table 2. Corrective Action Unit 139 Closure Activities Schedule

\begin{tabular}{|l|c|c||}
\hline \multicolumn{1}{|c|}{ CORRECTIVE ACTION SiTE } & START DATE & END DATE \\
\hline \hline 03-35-01, Burn Pit & December 8, 2008 & January 26, 2009 \\
\hline 04-99-01, Contaminated Surface Debris & December 9, 2008 & January 26, 2009 \\
\hline 06-19-03, Waste Disposal Trenches & December 3, 2008 & April 8, 2009 \\
\hline
\end{tabular}

\subsection{Site Plan/Survey Plat}

As-built drawings were not required for CAU 139 closure activities. 
CAU 139 Closure Report

Section: Closure Activities

Revision: 0

Date: July 2009

THIS PAGE INTENTIONALLY LEFT BLANK 


\subsection{WASTE DISPOSITION}

This section describes the waste streams generated during closure activities and their final disposition.

\subsection{WASTE STREAMS AND Disposal}

Waste streams included sanitary waste and LLW. Waste disposition is discussed in detail in the following sections. Waste disposition documentation is included as Appendix C.

\subsubsection{Sanitary Waste}

Sanitary waste included surface debris and debris removed from the locations of geophysical anomalies at CAS 03-35-01, Burn Pit, and CAS 04-99-01, Contaminated Surface Debris. A total of approximately $120 \mathrm{yd}^{3}$ of sanitary waste was removed from these sites and transported in end-dump trucks to the Area 9 U10c Sanitary Landfill for disposal. In addition, surface debris was removed from CAS 06-19-03, Waste Disposal Trenches, prior to installation of the cover. A total of approximately $120 \mathrm{yd}^{3}$ of sanitary waste was removed from this site and transported in end-dump trucks to either the Area 23 Sanitary Landfill or the Area 9 U10c Sanitary Landfill for disposal.

\subsubsection{Low-Level Waste}

A total of approximately $19 \mathrm{yd}^{3}$ of LLW was generated during closure activities. LLW included soil and debris from CAS 03-35-01, Burn Pit, and CAS 04-99-01, Contaminated Surface Debris. LLW was packaged in B-25 boxes and transported to the Area 5 Radioactive Waste Management Site for disposal. 
CAU 139 Closure Report

Section: Waste Disposition

Revision: 0

Date: July 2009

THIS PAGE INTENTIONALLY LEFT BLANK 


\subsection{CLOSURE VERIFICATION RESULTS}

Site closure was verified by visual observations and site closure photographs to document that closure activities had been completed and by collecting and analyzing soil verification samples. Soil verification samples were collected from the excavations at CAS 03-35-01, Burn Pit, and CAS 04-99-01, Contaminated Surface Debris, to verify that the remaining soil did not contain contamination above action levels. The results showed that no COCs above the action levels are present at the sites. Sample results are summarized in Table 3 and Table 4, and the laboratory data reports are included in Appendix B. Photographs documenting site conditions before and after closure activities are included as Appendix E.

TABle 3. VERIfication SAMPle Results fOR CORREctiVE ACTION Site 03-35-01

\begin{tabular}{||c|c|c|c|c|c|c|c||}
\hline \multirow{2}{*}{ ANALYTE } & \multirow{2}{*}{$\begin{array}{c}\text { ACTION } \\
\text { LEVEL } \\
(\mathbf{p C i} / \mathbf{g})\end{array}$} & \multicolumn{6}{|c||}{ SAMPLE RESULTS (pCi/g) } \\
\cline { 3 - 8 } & 13 & $-0.0031^{*}$ & $0.0154^{*}$ & $-0.00388^{*}$ & $0.00915^{*}$ & $0.0156^{*}$ & 0.0878 \\
\hline \hline Plutonium-238 & 12.7 & 0.173 & 0.138 & 0.275 & 0.290 & 0.277 & 0.812 \\
\hline Plutonium-239/240 & $12.02-02$ & B-02-03 & B-02-04 & B-03-01 & B-03-02 \\
\hline
\end{tabular}

pCi/g: picocurie(s) per gram

*not detected above the laboratory's minimum detectable concentration

TABle 4. Verification SAMPle Results for CoRrective ACTION Site 04-99-01

\begin{tabular}{||c|c|c|c|c||}
\hline \multirow{2}{*}{ ANALYTE } & \multirow{2}{*}{$\begin{array}{c}\text { ACTION LEVEL } \\
\mathbf{( p C i / g )}\end{array}$} & \multicolumn{3}{|c||}{ SAMPLE RESULTS (pCi/g) } \\
\cline { 3 - 5 } & 13 & $\mathbf{D - 0 1 - 0 1}$ & $\mathbf{D - 0 1 - 0 2}$ & $\mathbf{D - 0 1 - 0 3}$ \\
\hline \hline Plutonium-238 & 12.7 & 0.0343 & 0.0391 & $0.0181^{*}$ \\
\hline Plutonium-239/240 & 0.0835 & 0.162 & 0.0569 \\
\hline
\end{tabular}

pCi/g: picocurie(s) per gram

*not detected above the laboratory's minimum detectable concentration

\subsection{Data Quality Assessment}

Accurate and defensible analytical data were collected to verify that the closure objectives were met. Analytical data results are included as Appendix B. The following sections describe the quality assurance (QA) and quality control (QC) procedures, data validation process, and a reconciliation of the CSM with actual findings during closure activities. More detail on the QA/QC procedures can be found in the CAP for CAU 139 (NNSA/NSO, 2007b) and the QAPP (NNSA/NV, 2002).

\subsubsection{Quality Assurance and Quality Control Procedures}

Verification samples were collected with disposable sampling equipment and placed in appropriately labeled sample containers secured with custody seals. All samples were labeled with a unique sample number, placed on ice, and transported under strict chain of custody. Standard QA/QC samples were collected (i.e., one blind duplicate per batch). Samples were 
analyzed by certified offsite contract laboratories. Analytical results were validated at the laboratory using stringent QA/QC procedures, including matrix spike/matrix spike duplicates, spiked surrogate recovery analysis, verification of analytical results, and data quality indicator requirements. Detailed information regarding the QA/QC program requirements can be found in the QAPP (NNSA/NV, 2002).

\subsubsection{Data Validation}

Data validation was performed according to the QAPP (NNSA/NV, 2002), which is based on the EPA functional guidelines for data quality (EPA, 1994; 1999). Data were reviewed to ensure that samples were appropriately processed and analyzed and that the results are valid. All sample data were validated at the Tier I level.

No anomalies were discovered in the data that would discredit any of the sample results. Data met the required data quality indicators (i.e., precision, accuracy, sensitivity, completeness, comparability, and representativeness). While only summary laboratory QC data are included in Appendix B, the complete datasets, including validation reports, are maintained in the project files and available upon request.

\subsubsection{Conceptual Site Models}

CSMs were developed and presented in the approved CAIP for CAU 139 (NNSA/NSO, 2006). The CSMs were confirmed by soil sample results and verified during closure activities.

\subsection{USE RESTRICTION}

URs have been implemented for the following CASs:

- CAS 04-08-02, Waste Disposal Site

- CAS 06-19-03, Waste Disposal Trenches

- CAS 09-23-01, Area 9 Gravel Gertie

\subsubsection{Corrective Action Site 04-08-02, Waste Disposal Site}

An administrative UR has been implemented at this site for radionuclides present at concentrations above the PALs based on construction, commercial, and industrial land-use scenarios but not exceeding the FALs calculated based on a remote work area scenario. Pu-239 is also present but will be addressed under the Soils Project. The area was recorded in the FIMS database as an administrative UR to protect future workers from exposure to radionuclides should the land use scenario change from that used to calculate the FALs. The administrative UR prevents future site activities that would result in an exposure to site workers greater than the remote work area scenario (42 days per year for 25 years). No postings or post-closure monitoring are required. The CAU Use Restriction Information form and a figure showing the locations of the surveyed points delineating the UR area are included in Appendix D. 


\subsubsection{Corrective Action Site 06-19-03, Waste Disposal Trenches}

A UR has been implemented for radioactive and/or hazardous COCs assumed to be present in the trenches. The future use of the UR area is restricted from any activity that may alter or modify the containment controls, unless appropriate concurrence is obtained in advance. UR warning signs were posted to warn against intrusive activity according to the FFACO UR posting guidance (FFACO, 2003). Annual site inspections will be required to ensure that the signs are intact and legible and that the UR is maintained. Details on the post-closure requirements are included in Section 5.2. The CAU Use Restriction Information form and a figure showing the locations of the surveyed points delineating the UR area are included in Appendix D.

\subsubsection{Corrective Action Site 09-23-01, Area 9 Gravel Gertie}

A UR has been implemented for uranium assumed to be present based on process knowledge. The future use of the UR area is restricted from any activity that may alter or modify the containment controls, unless appropriate concurrence is obtained in advance. UR warning signs were posted to warn against intrusive activity according to the FFACO UR posting guidance (FFACO, 2003). Annual site inspections will be required to ensure that the signs are intact and legible and that the UR is maintained. Details on the post-closure requirements are included in Section 5.2. The CAU Use Restriction Information form and a figure showing the locations of the surveyed points delineating the UR area are included in Appendix D. 
CAU 139 Closure Report

Section: Closure Verification

Revision: 0

Date: July 2009

THIS PAGE INTENTIONALLY LEFT BLANK 


\subsection{CONCLUSIONS AND RECOMMENDATIONS}

\subsection{CONCLUSIONS}

The following site closure activities were performed at CAU 139 as documented in this CR:

- At CAS 03-35-01, Burn Pit, soil and debris were removed and disposed as LLW, and debris was removed and disposed as sanitary waste.

- At CAS 04-08-02, Waste Disposal Site, an administrative UR was implemented. No postings or post-closure monitoring are required.

- At CAS 04-99-01, Contaminated Surface Debris, soil and debris were removed and disposed as LLW, and debris was removed and disposed as sanitary waste.

- At CAS 06-19-02, Waste Disposal Site/Burn Pit, no work was performed.

- At CAS 06-19-03, Waste Disposal Trenches, a native soil cover was installed, and a UR was implemented.

- At CAS 09-23-01, Area 9 Gravel Gertie, a UR was implemented.

- At CAS 09-34-01, Underground Detection Station, no work was performed.

\subsection{Post-Closure ReQuirements}

CAS 06-19-03, Waste Disposal Trenches, and CAS 09-23-01, Area 9 Gravel Gertie, require post-closure inspections. Inspections will be performed annually to verify that the UR warning signs are in place and legible and that the UR is maintained. The interior of the UR area will be inspected to confirm there have been no disturbances to the area. Maintenance or repair needs that are identified, such as sign or post repair, will be completed prior to the following inspection and documented in writing at the time the work is done. Inspection results will be documented in the annual combined NTS post-closure letter report. The report will include a discussion of observations and will describe any maintenance activities performed since the last inspection. A copy of the inspection checklist will be provided, and the field notes will be maintained in the project files. The letter report will be submitted to the Nevada Division of Environmental Protection (NDEP).

\subsection{RECOMMENDATIONS}

Since closure activities for CAU 139 have been completed following the NDEP-approved CAP for CAU 139 (NNSA/NSO, 2007b) as documented in this report, NNSA/NSO requests the following:

- A Notice of Completion be provided by NDEP to NNSA/NSO for closure of CAU 139.

- The transfer of CAU 139 from Appendix III to Appendix IV, Closed Corrective Action Units, of the FFACO (1996, as amended February 2008). 
CAU 139 Closure Report

Section: Conclusions \& Recommendations

Revision: 0

Date: July 2009

THIS PAGE INTENTIONALLY LEFT BLANK 


\subsection{REFERENCES}

EPA, see U.S. Environmental Protection Agency.

Federal Facility Agreement and Consent Order, 1996 (as amended February 2008). Agreed to by the State of Nevada; U.S. Department of Energy, Environmental Management; U.S. Department of Defense; and U.S. Department of Energy, Legacy Management.

Federal Facility Agreement and Consent Order, 2003. Use Restriction Posting Guidance.

FFACO, see Federal Facility Agreement and Consent Order.

Murphy, T., Nevada Division of Environmental Protection, 2004. Letter to R. M. Bangerter, Jr. (NNSA/NSO) entitled, "Review of Industrial Sites Project Document 'Guidance for Calculating Industrial Sites Project Remediation Goals for Radionuclides in Soil Using the Residual Radiation (RESRAD) Computer Code,” November 19, 2004. Las Vegas, NV.

National Council on Radiation Protection and Measurements, 1999. Recommended Screening Limits for Contaminated Surface Soil and Review of Factors Relevant to Site-Specific Studies, NCRP Report No. 129. Washington, D.C.

NCRP, see National Council on Radiation Protection and Measurements.

NNSA/NSO, see U.S. Department of Energy, National Nuclear Security Administration Nevada Site Office.

NNSA/NV, see U.S. Department of Energy, National Nuclear Security Administration Nevada Operations Office.

U.S. Department of Energy, National Nuclear Security Administration Nevada Operations Office, 2002. Nevada Environmental Restoration Project Industrial Sites Quality Assurance Project Plan, Nevada Test Site, Nevada. DOE/NV--372-REV.3. Las Vegas, NV.

U.S. Department of Energy, National Nuclear Security Administration Nevada Site Office, 2006. Corrective Action Investigation Plan for Corrective Action Unit 139: Waste Disposal Sites, Nevada Test Site, Nevada. DOE/NV--1114. Las Vegas, NV.

U.S. Department of Energy, National Nuclear Security Administration Nevada Site Office, 2007a. Corrective Action Decision Document for Corrective Action Unit 139: Waste Disposal Sites, Nevada Test Site, Nevada. DOE/NV--1179. Las Vegas, NV.

U.S. Department of Energy, National Nuclear Security Administration Nevada Site Office, 2007b. Corrective Action Plan for Corrective Action Unit 139: Waste Disposal Sites, Nevada Test Site, Nevada. DOE/NV--1217. Las Vegas, NV. 
U.S. Environmental Protection Agency, 1994. Guidance for the Data Quality Objectives Process. EPA QA/G-4. Washington, D.C.

U.S. Environmental Protection Agency, 1999. Contract Laboratory Program National Functional Guidelines for Organic Data Review. EPA540/R-99/008. Washington, D.C. 


\section{APPENDIX A*}

\section{DATA QUALITY OBJECTIVES}

*As presented and published in Appendix A of the approved Corrective Action Investigation Plan for Corrective Action Unit 139: Waste Disposal Sites, Nevada Test Site, Nevada, 2006, DOE/NV--1114. Las Vegas, NV. 
CAU 139 Closure Report

Section: Appendix A

Revision: 0

Date: July 2009

THIS PAGE INTENTIONALLY LEFT BLANK 


\section{A.1.0 Introduction}

The DQO process described in this appendix is a seven-step strategic systematic planning method based on the scientific method that was used to plan data collection activities and define performance criteria for the CAU 139, Waste Disposal Sites, field investigation. The DQOs are designed to ensure that the data collected will provide sufficient and reliable information to identify, evaluate, and technically defend recommended corrective actions (i.e., no further action, closure in place, or clean closure). Existing information about the nature and extent of contamination at the majority of the CASs in CAU 139 is insufficient to evaluate and select preferred corrective actions; therefore, a CAI will be conducted.

The CAU 139 investigation will be based on the DQOs presented in this appendix as developed by representatives of the NDEP and the NNSA/NSO. The seven steps of the DQO process presented in Section A.3.0 through Section A.9.0 were developed in accordance with EPA Guidance for the Data Quality Objectives Process (EPA, 2000b) and Guidance for Quality Assurance Project Plans (EPA, 2002). The DQO process presented herein is based on the EPA Quality System Document for DQOs entitled Data Quality Objectives Process for Hazardous Waste Site Investigations, (EPA, 2000a) and the CAS-specific information presented in Section A.2.0.

The DQO process presents a judgmental sampling approach. In general, the procedures used in the DQO process provide:

- A scientific basis for making inferences about a site (or portion of a site) based on environmental data or process knowledge.

- A basis for defining decision performance criteria and assessing the achieved decision quality of the data collection design.

- Criteria for knowing when site investigators should stop data collection (i.e., when sufficient information is available to support decisions).

- A basis for demonstrating an acceptable level of confidence in the sampling approach to generate the appropriate quantity and quality of information necessary to minimize the potential for making decision errors. 


\section{A.2.0 Background Information}

The following seven CASs that comprise CAU 139 are located in Areas 3, 4, 6, and 9 of the NTS, as shown in Figure A.2-1:

- CAS 03-35-01, Burn Pit

- CAS 04-08-02, Waste Disposal Site

- CAS 04-99-01, Contaminated Surface Debris

- CAS 06-19-02, Waste Disposal Site/Burn Pit

- CAS 06-19-03, Waste Disposal Trenches

- CAS 09-23-01, Area 9 Gravel Gertie

- CAS 09-34-01, Underground Detection Station

The following sections (Section A.2.1 through Section A.2.7) provide a CAS description, physical setting and operational history, release information, and previous investigation results for each CAS in CAU 139. The CAS-specific COPCs are provided in the following sections. Many of the COPCs are based on a conservative evaluation of possible site activities considering the incomplete site histories of the CASs and considering contaminants found at similar NTS sites. Targeted contaminants are defined as those contaminants that are known or that could be reasonably suspected to be present within the CAS based on previous sampling or process knowledge.

\section{A.2.1 Corrective Action Site 03-35-01, Burn Pit}

Corrective Action Site 03-35-01 consists of the soil and release within the area located northeast of the Buster Jangle Wye (BJY) intersection in Area 3 of the NTS. Debris such as metal cans, wood, cable, concrete, cinder blocks, and other scrap is present throughout the site. Figure A.2-2 shows a site sketch of the CAS.

Physical Setting and Operational History - Corrective Action Site 03-35-01 is located near the BJY intersection in Area 3 of the NTS. Documentation originally used to include this CAS in the FFACO is believed to actually be discussing CAS 03-08-01, located several hundred feet to the south. A small area containing a few rusted cans and minimal metal debris and building materials (i.e., cinder blocks and chunks of concrete) is the current basis of this CAS. The ground has been disturbed recently with the cleanup of CAS 03-99-11. The area is flat with gravel ranging in size from 0.5 in. to 


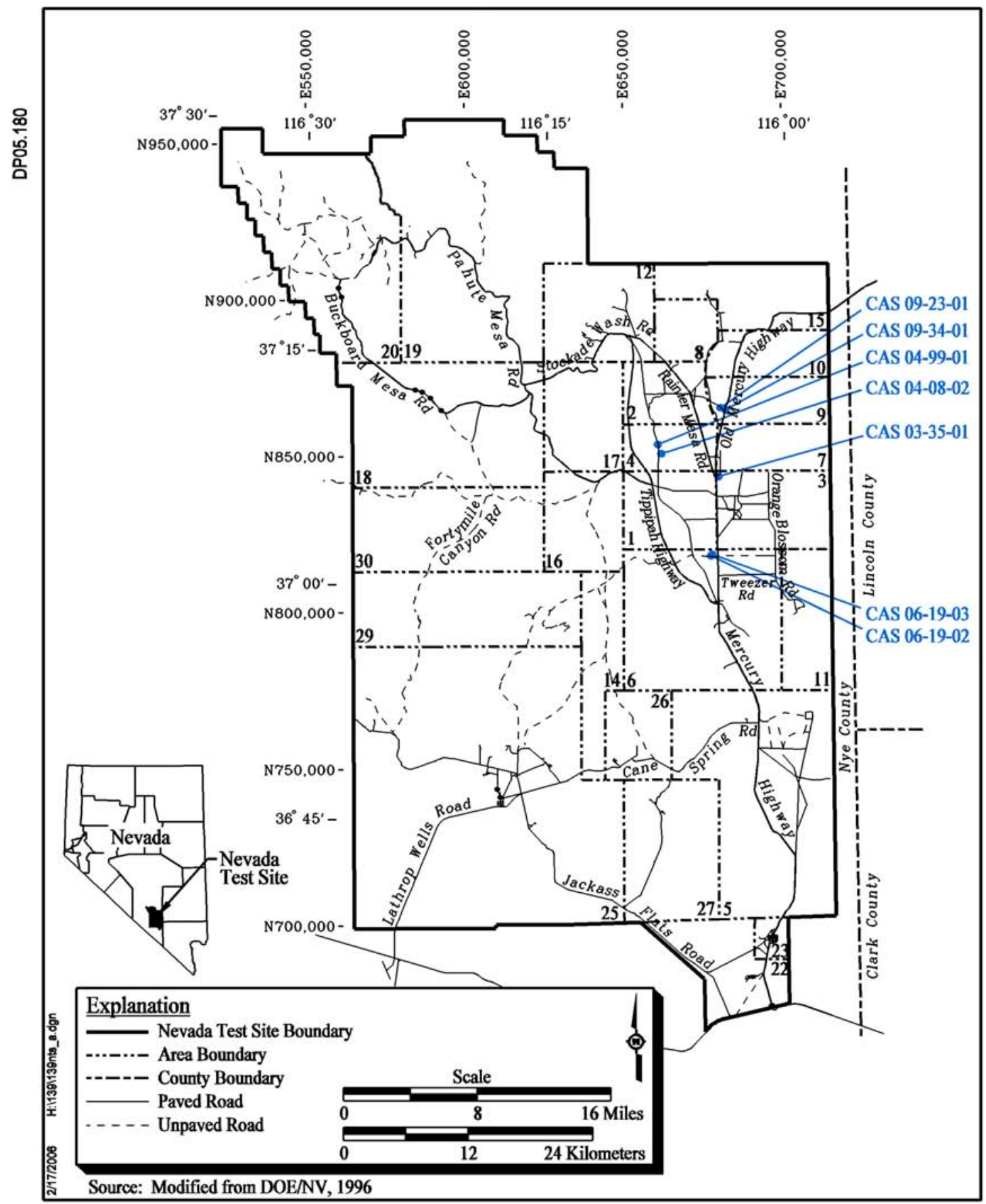

Figure A.2-1

Corrective Action Unit 139, CAS Location Map 


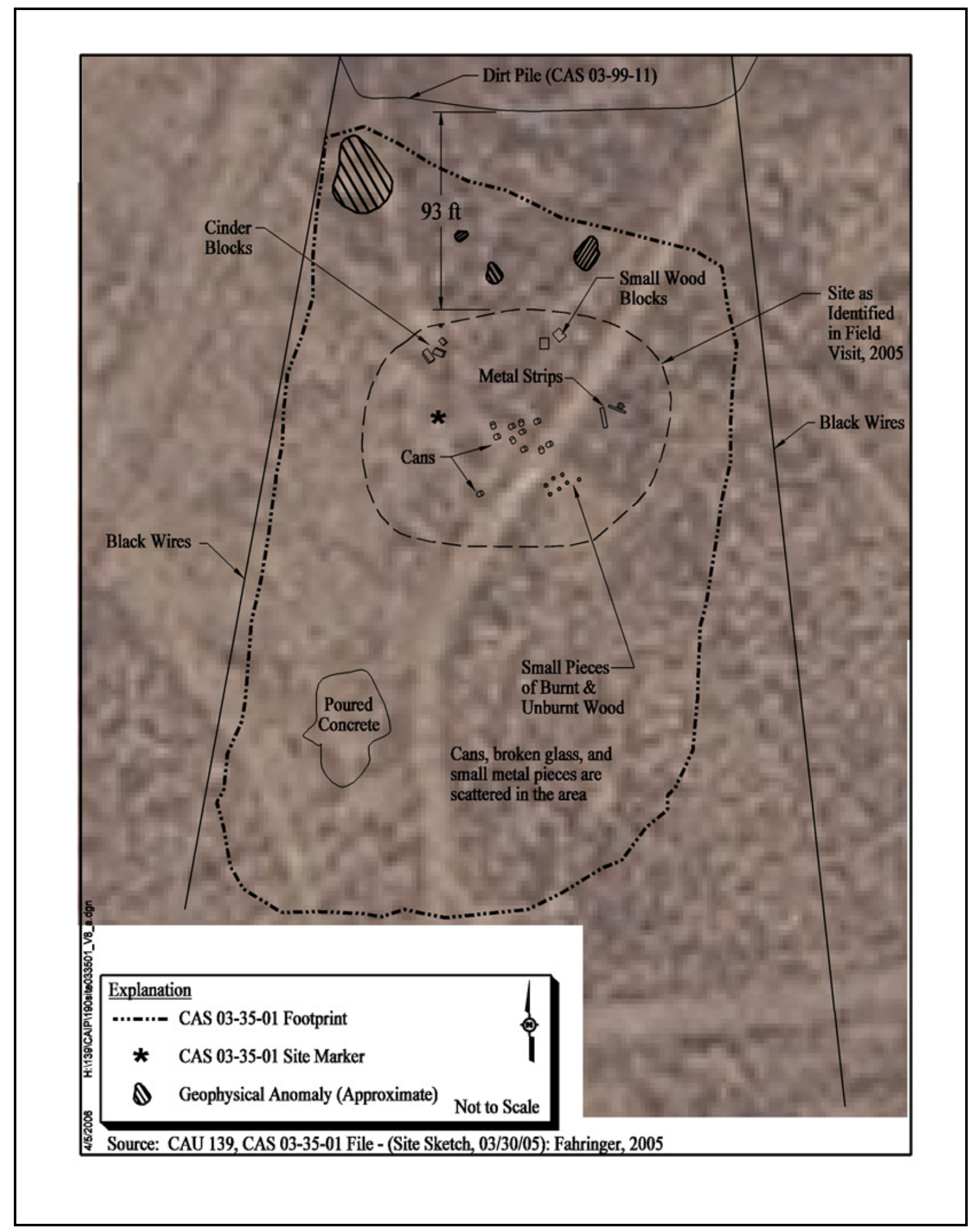

Figure A.2-2

Site Sketch of CAS 03-35-01, Burn Pit 
6 in. The area is grown over with vegetation. Water flows from northwest towards the southeast. The area is bordered on the west by a dirt road. There is no documented operational history for this area.

Release Information - There is no documented release information available. The source of any release is assumed to be the debris and any sources from the burning of debris.

Previous Investigation Results - Geophysical surveys using EM31 and EM61-MKII equipment were conducted and a number of subsurface anomalies were identified within the area of the CAS (Fahringer, 2005). Neither radiological survey data nor previous sampling data have been gathered.

\section{A.2.2 Corrective Action Site 04-08-02, Waste Disposal Site}

Corrective Action Site 04-08-02 consists of potential releases from within the area located south of the intersection of 4-04 Road and Orange Road. Debris such as a metal grate, cable, spindle, metal stakes, and chicken wire is present at the site. The only standing structure within the CAS is a wire fence that partially surrounds the area. Figure A.2-3 shows a site sketch of the CAS.

Physical Setting and Operational History - Corrective Action Site 04-08-02 is located in Area 4 of the NTS. The site is generally flat with gravel ranging in size from $0.5 \mathrm{in}$. to 6 in. The area is partially fenced and has a natural wash running along the south side of the site, with soil deposited at one location to apparently dam any incoming water or divert flow. A large portion of the area of the CAS has been leveled and a natural wash has developed from the leveled area out of the CAS. The only operational history for this location is a reference in the Long Range Radioactive Waste Consolidation Plan. The area is currently inactive and abandoned.

Release Information - There is no documented release information available. The source of any release is assumed to be the items once stored at this location associated with the Long Range Radioactive Waste Consolidation Plan (REECo, 1982).

Previous Investigation Results - A radiological survey conducted in 2002 shows the maximum gamma radioactivity emission rate to be approximately 10 times the mean background (Alderson, 2002). The contaminated area appears to be confined to the outline of a former pad or laydown area. 


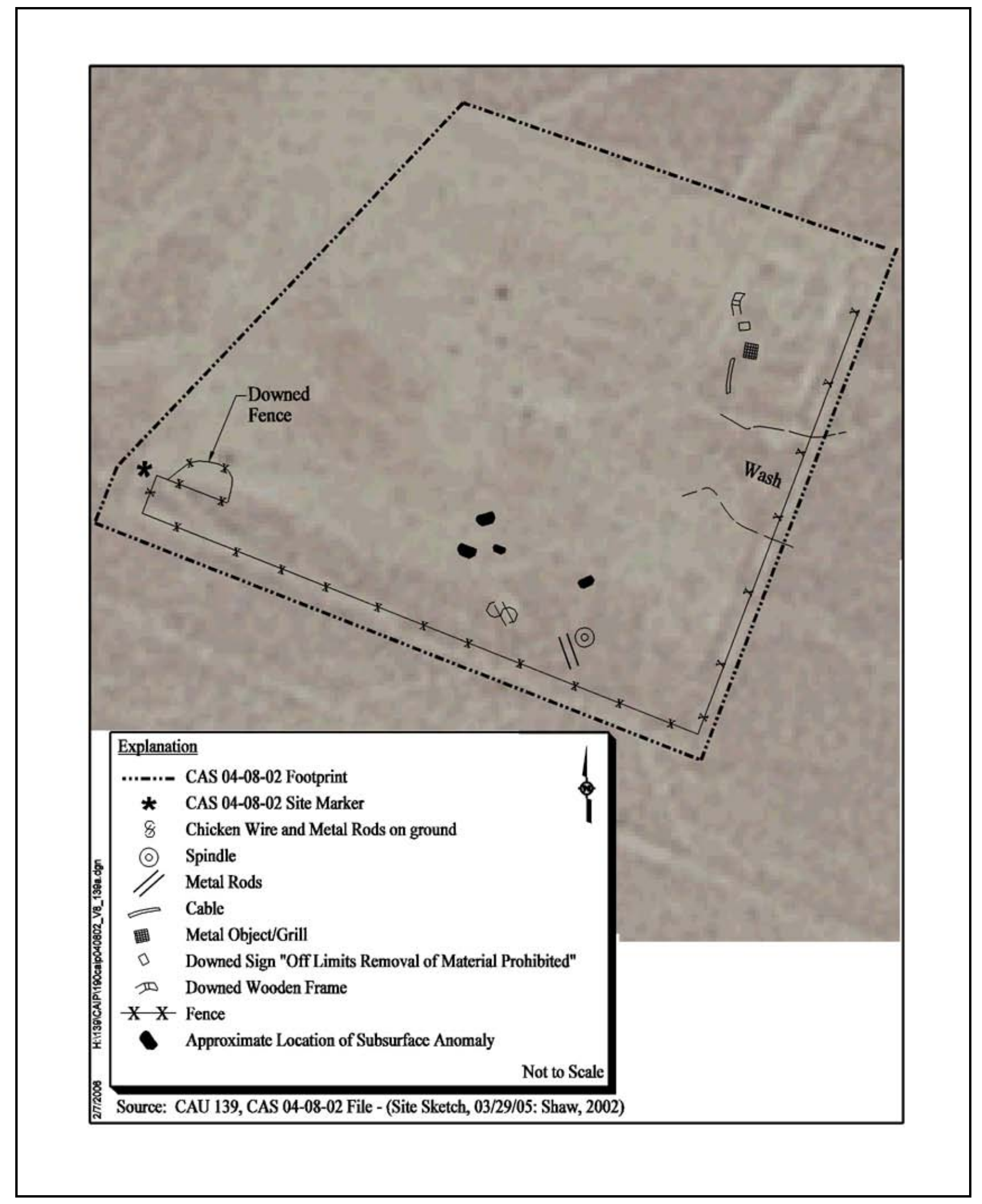

Figure A.2-3

Site Sketch of CAS 04-08-02, Waste Disposal Site 
Geophysical surveys using EM31 and EM61-MKII equipment were conducted and a few subsurface anomalies were identified within the area of the CAS (Shaw, 2002). No samples have been collected or analyzed.

\section{A.2.3 Corrective Action Site 04-99-01, Contaminated Surface Debris}

Corrective Action Site 04-99-01 consists of the soil and release within the area located approximately $75 \mathrm{ft}$ west of the intersection of the 4-04 Road and Orange Road. Debris such as rusted metal cans and rusted metal stakes are present at the site. Figure A.2-4 shows a site sketch of the CAS.

Physical Setting and Operational History - Corrective Action Site 04-99-01 is located in Area 4 of the NTS. The site slopes west to east toward the valley floor with gravel ranging in size from 0.5 in. to 6 in. The area has small berms and shallow depressions running the width of the area, parallel to the road (approximately $60 \mathrm{ft}$ by $5 \mathrm{ft}$ ) exhibiting no apparent effect on water flow through the area. Four t-posts are standing at the corners of the CAS with four metal stakes driven into the ground along one of two shallow depressions. The only operational history for this location is a reference in the Long Range Radioactive Waste Consolidation Plan as a temporary storage area (REECo, 1982). The area is currently inactive and abandoned.

Release Information - There is no documented release information available. The source of any release is assumed to be the debris currently present at the site and any items once stored at this location associated with the Long Range Radioactive Waste Consolidation Plan (REECo, 1982).

Previous Investigation Results - A radiological survey conducted in 2002 shows the maximum gamma radioactivity emission rate to not be significantly different than the mean background (Alderson, 2002). Geophysical surveys using EM31 and EM61-MKII equipment were conducted and a few subsurface anomalies were identified within the area of the CAS (Shaw, 2002).

\section{A.2.4 Corrective Action Site 06-19-02, Waste Disposal Site/Burn Pit}

Corrective Action Site 06-19-02 consists of the soil and release within the area located adjacent to Building 6-660 near Well 3 in Area 6 of the NTS. Debris such as scrap metal, wood, and decaying 


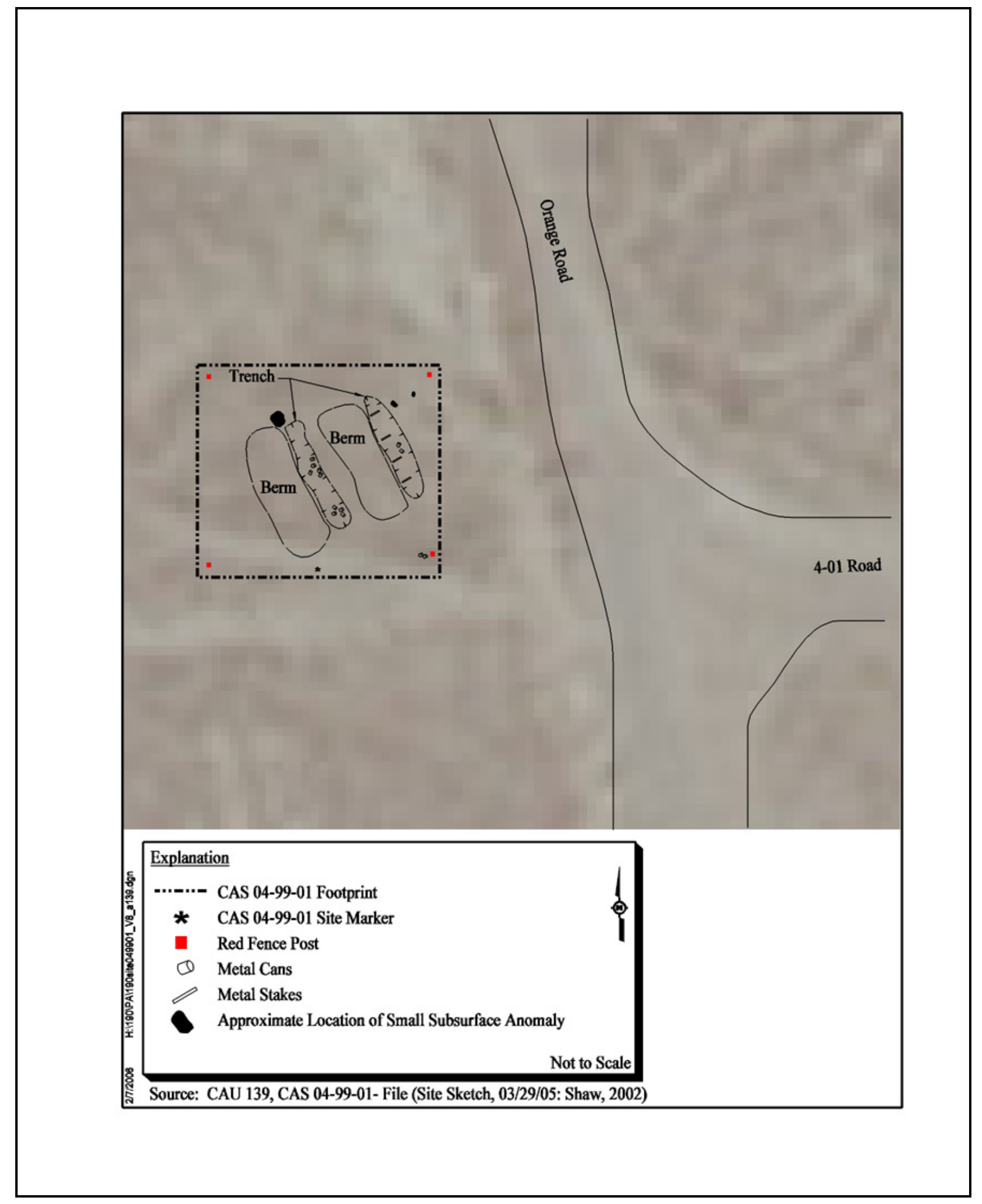

Figure A.2-4

Site Sketch of CAS 04-99-01, Contaminated Surface Debris 
fabric partially buried by drift sand are present at the site. Figure A.2-5 shows a site sketch of the CAS.

Physical Setting and Operation History - Corrective Action Site 06-19-02 is located in Area 6 of the NTS, approximately $200 \mathrm{ft}$ northwest of Well 3. The site is generally flat with gravel at the surface. Vegetation exists throughout the area. A dirt road circles to the south of the CAS and provides access to the fill spout at Well 3. A chain-link fence establishes the perimeter of the burn pit and a wire fence establishes the perimeter of an old animal pen.

The animal pen was part of a group of animal holding pens, but the history of the waste disposal area and fenced burn pit area is uncertain. It is believed that the sites provided support for the U.S. Public Health Service Animal Investigation Program. The area is currently inactive and abandoned.

Release Information - There is no documented release information available. The source of any release is assumed to be the waste products from the animals once held in these pens. The animals ingested radioactive feed as part of the experiments. The excrement from the animals has the potential to contain radioactivity. In the area identified as the burn pit, charred wood and other surface debris is present.

Previous Investigation Results - A radiological survey conducted in 2002 shows the maximum gamma radioactivity emission rate to not be significantly different than the mean background (Alderson, 2002). Geophysical surveys using EM31 and EM61-MKII equipment were conducted identifying no buried items within the area of the CAS (Shaw, 2002).

\section{A.2.5 Corrective Action Site 06-19-03, Waste Disposal Trenches}

Corrective Action Site 06-19-03 consists of one known and other potential waste disposal trenches located north of former Building 6-660. The waste buried in the trench(es) include the remains of animals dissected and analyzed as part of the EPA Farm activities as well as other wastes that were generated as part of the activities such as a complete carcass and animal fluids. Figure A.2-6 shows a site sketch of the CAS. 


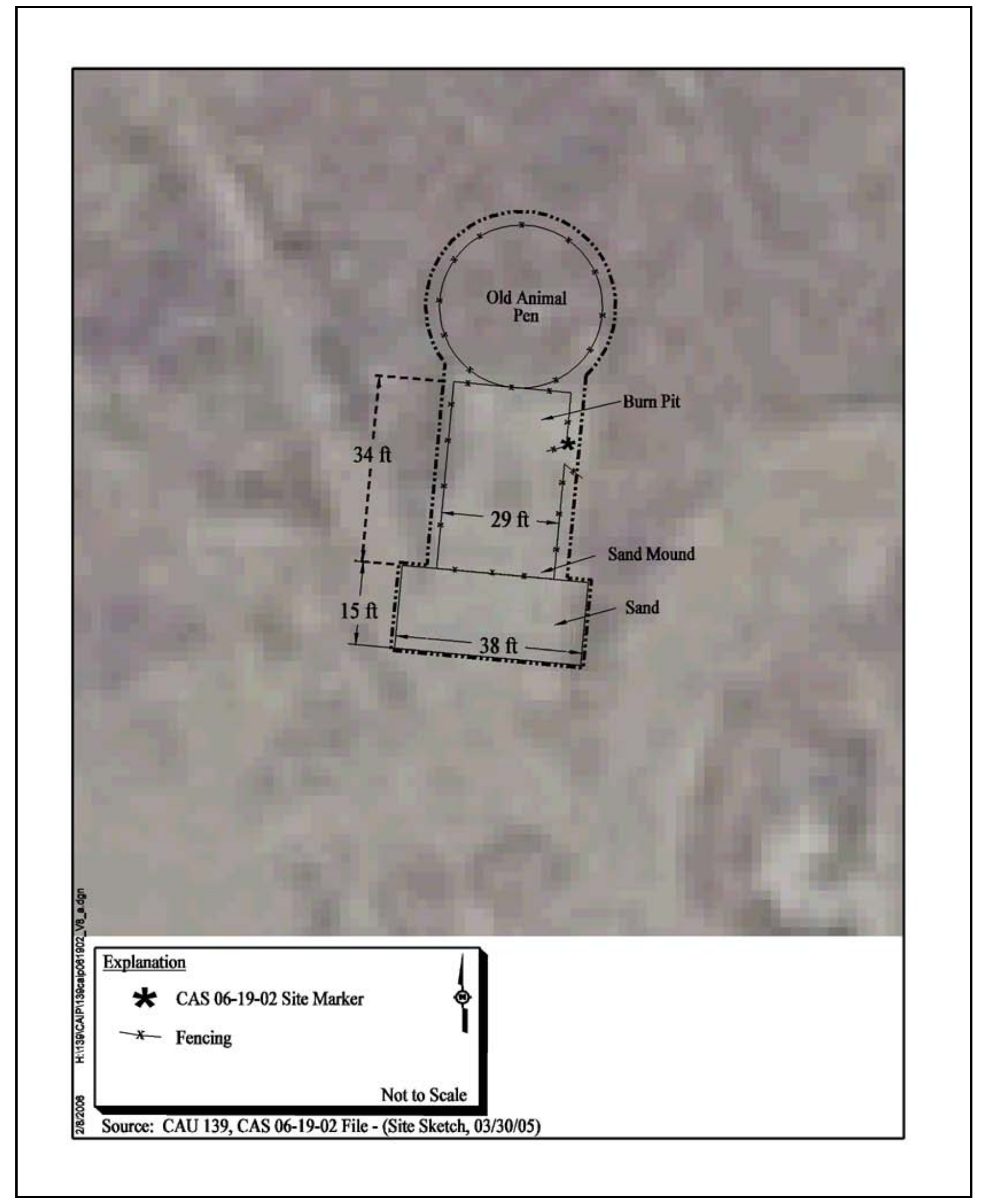

Figure A.2-5

Site Sketch of CAS 06-19-02, Waste Disposal Site/Burn Pit 


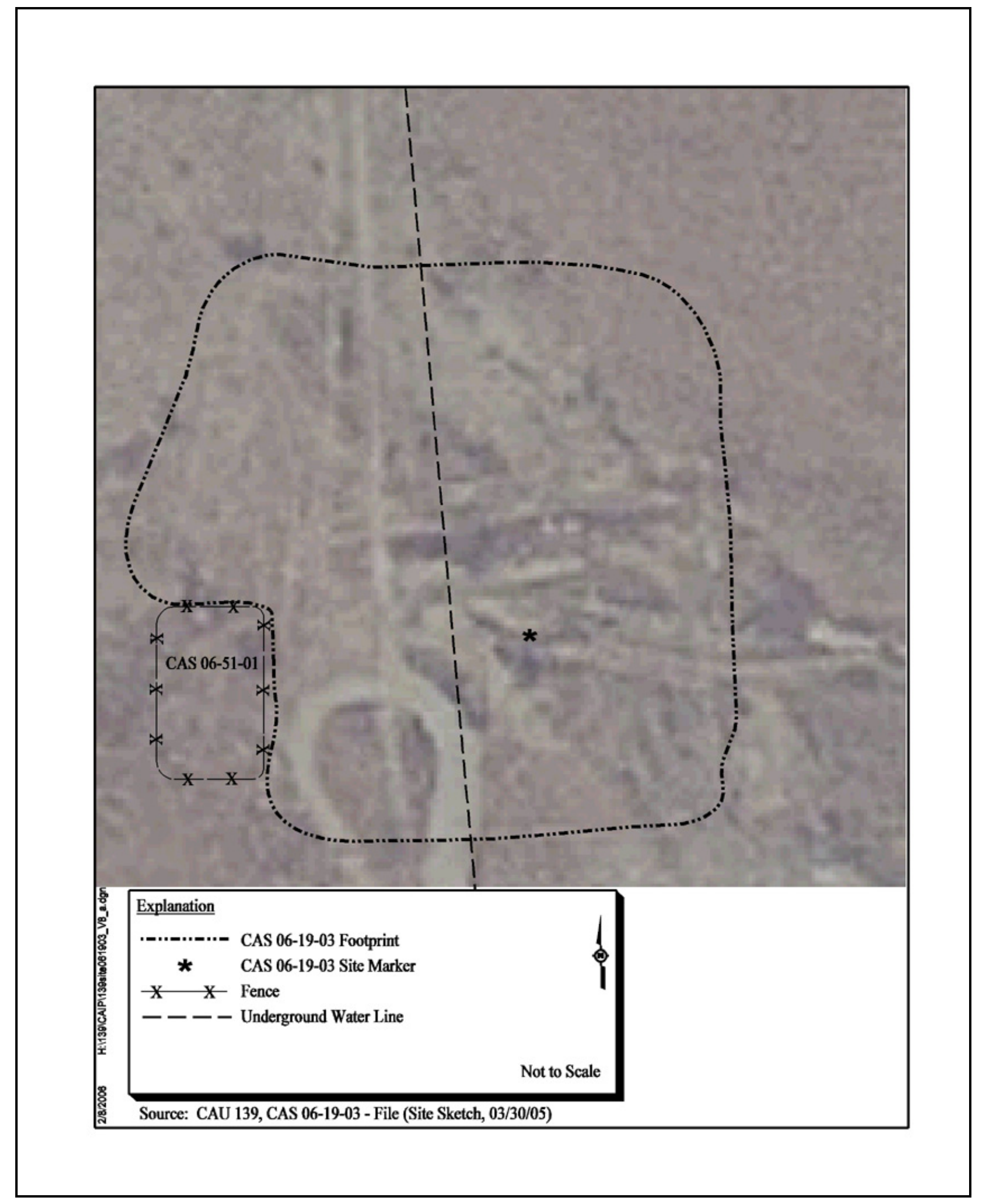

Figure A.2-6

Site Sketch of CAS 06-19-03, Waste Disposal Trenches 
Physical Setting and Operation History - Corrective Action Site 06-19-03 is located in Area 6 of the NTS approximately $700 \mathrm{ft}$ north of Well 3. The site is generally flat with gravel at the surface. Vegetation exists throughout the area. An underground water line was installed in 2004 that bisects the area. An aboveground water line is present just west of the site. An unused dirt road runs parallel to the water line through the CAS.

During excavation activities for an underground water line in 2004, a waste trench was uncovered revealing buried remains of animals and small plastic containers that appeared to be filled with biological samples. The trench appears to run perpendicular to the water line from east to west. The water line project was completed and the excavation backfilled after four days of site investigation in which the waste from the trench was sampled and analyzed. The area is currently inactive and abandoned.

Release Information - There is no documented release information available. The source of any release is assumed to be the buried items. Some of the animal remains buried in the trench were found secured in sealed plastic bags and containers while others, such as the carcass of a cow, was found buried without containment.

Previous Investigation Results - A radiological survey conducted in 2001 shows the maximum gamma radioactivity emission rate to be not significantly different than the mean background (IT, 2001). Geophysical surveys using EM31 and EM61-MKII equipment were conducted, and an area assumed to be the trench where the animal remains were buried was identified (Fahringer, 2005). Samples collected during the 2004 water line excavation of the buried remains and surrounding soil revealed no contamination exceeding action levels (NNSA/NSO, 2004). Samples of soil from the trench walls, IDW, and of soil waste directly sampled were analyzed for a variety of constituents including VOCs, SVOCs, PCBs, TPH-DRO, TPH-GRO, RCRA metals, Be, herbicides, pesticides, gamma spectroscopy, Iso-U, Iso-Pu, and Sr-90. No other sampling information is available. 


\section{A.2.6 Corrective Action Site 09-23-01, Area 9 Gravel Gertie}

Corrective Action Site 09-23-01 consists of the soil and release within the area located along the 9-01 Road between the old Mercury Highway and Circle Road. Debris such as wood, various cables, and metal culverts are present throughout the site. Figure A.2-7 shows a site sketch of the CAS.

Physical Setting and Operational History - Corrective Action Site 09-23-01 is located in Area 9 of the NTS. The CAS consists of structures within an area posted with "Underground Radioactive Material” signs that include: a gravel gertie (a small concrete room with a ceiling comprised of approximately $20 \mathrm{ft}$ of gravel); a second smaller gravel mound; one concrete vault approximately $10 \mathrm{ft}$ by $5 \mathrm{ft}$ covered with wood with two large culverts protruding from the sides at the surface; and one circular vault approximately $4 \mathrm{ft}$ in diameter and approximately $15 \mathrm{ft}$ deep with rungs designed as steps and handholds allowing entry down one side with communication cabling lying on the bottom; in addition to minimal surface debris lying throughout the area.

This area was ground zero for the Tesla test (T9b) of Operation Teapot, an atmospheric nuclear test conducted in 1955, which resulted in large-scale surface contamination that is not being considered in this investigation. The Ganymede test of Operation Hardtack, II, was a zero-yield safety experiment that was detonated inside the Area 9 Gravel Gertie in 1958. The experiment conducted in the gravel-covered bunker was described as a successful containment of four devices comprised of uranium and PBX. Access to the area is restricted with two fences and posted with signs identifying underground radioactive material. There is a large amount of Trinity glass dispersed throughout the site. The toe of a berm extends into the fenced area and houses cables previously used to facilitate testing. The area is currently inactive and abandoned.

Release Information - No radiological contamination outside the gravel gertie was detected after the Ganymede experiment (DOE/NV, 2000). Process knowledge and operational history are the bases for determining that no hazardous contamination is present.

Previous Investigation Results - Aerial data and ground surveys confirmed the lack of alpha activity around the bunker area, but fission products and soil activation products were detectable at this site (DOE/NV, 2000a). An investigation conducted at a similar site (CAS 05-23-01, Gravel Gertie) 


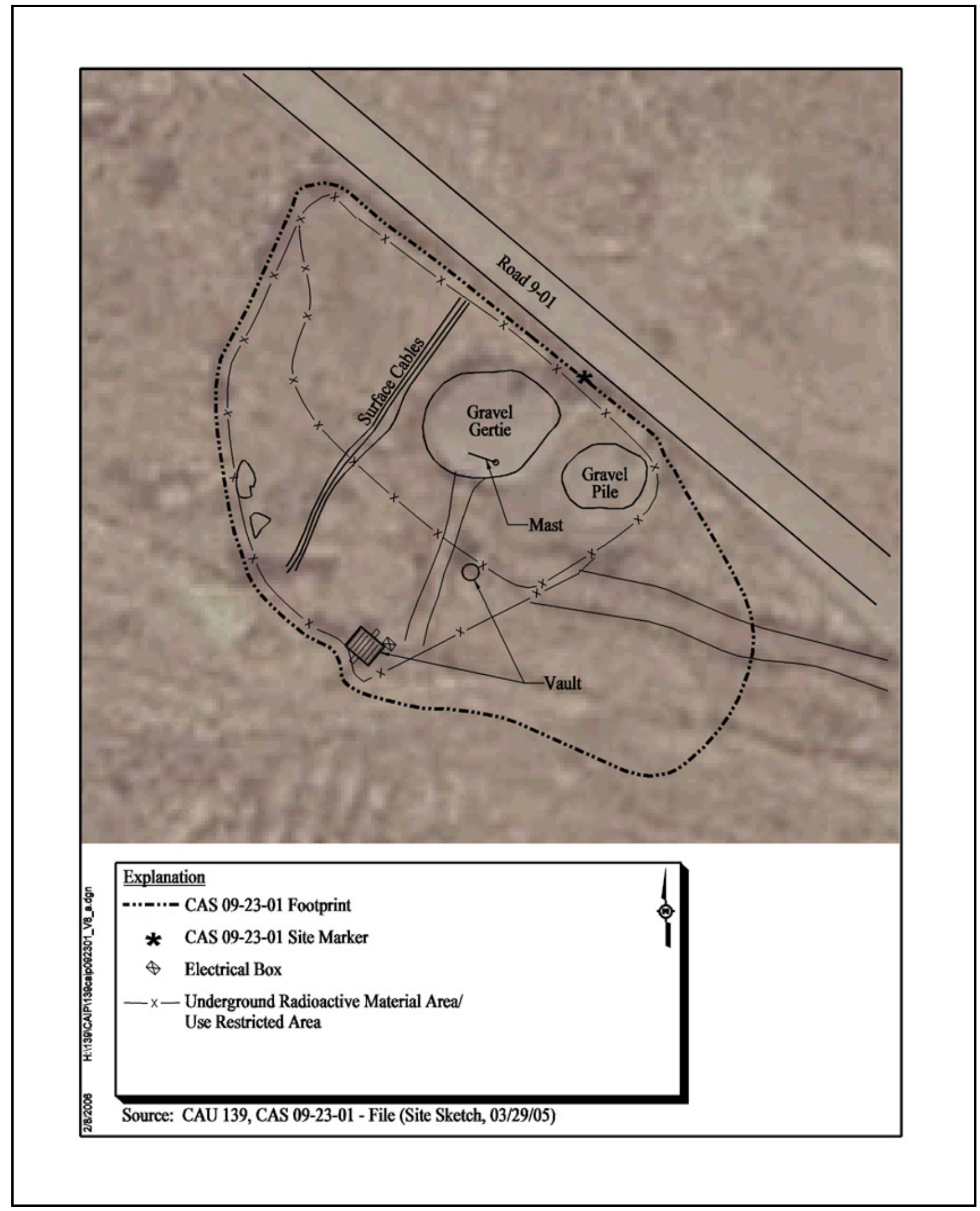

Figure A.2-7

Site Sketch of CAS 09-23-01, Area 9 Gravel Gertie 
determined that uranium contamination is present within the internal structure and that it is not practical to collect samples from inside the gravel gertie.

\section{A.2.7 Corrective Action Site 09-34-01, Underground Detection Station}

Corrective Action Site 09-34-01 consists of a station identified as Bunker 9-300 located at the northeast corner of the interesection of the old Mercury Highway and 9-01 Road. Figure A.2-8 shows a site sketch of the CAS.

Physical Setting and Operational History - Corrective Action Site 09-34-01, identified as Bunker 9-300, is located in Area 9 of the NTS. The bunker is a underground facility buried approximately $15 \mathrm{ft}$ bgs. A soil mound is present over the bunker location.

Bunker 9-300 (also referred to as Bunker Z-900) was used to house detection equipment for monitoring the several nuclear tests that were detonated throughout the immediate area. The bunker is only accessible via an elevator that is assumed to have not been operational for approximately 30 to 40 years. It is not considered safe to enter the bunker. The area is currently inactive and abandoned.

Release Information - There is no documented release information available.

Previous Investigation Results - No previous investigation results from Bunker 9-300 are available. Investigations in the immediate area of Bunker 9-300 include CAU 380 and CAU 464. Corrective Action Unit 380 included a transformer west of Station 9-63 determined to be non-PCB. No soil staining was observed. Corrective Action Unit 464, CAS 09-02-01, included a 1,000-gallon diesel fuel tank, located on the east side of Station 9-63, which provided fuel to the generators formerly housed in Station 9-63. The CAU was clean closed after 15 cubic yards of soil was removed, verification soil samples were collected, and analysis for contaminants were determined to be below action levels. 


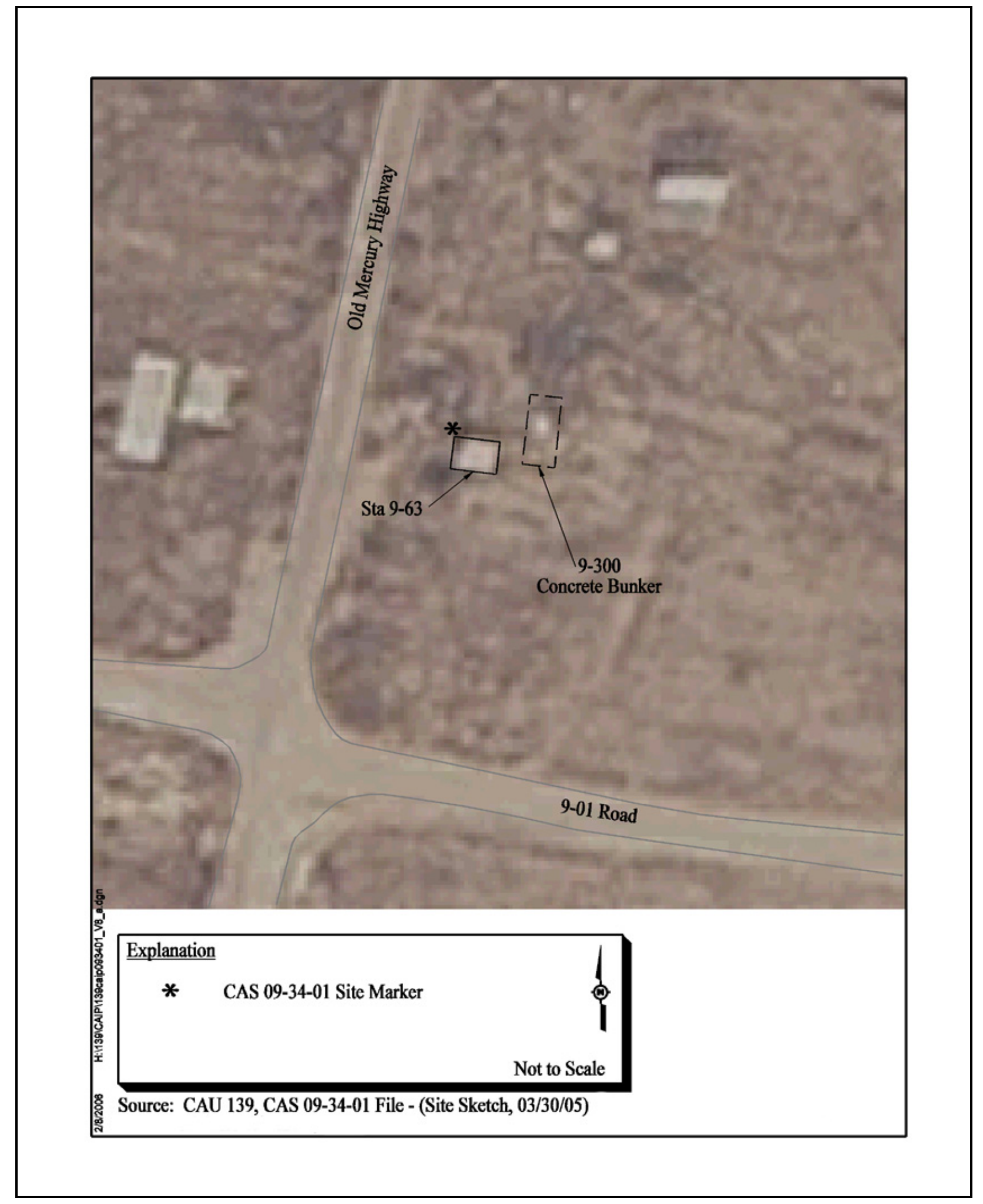

Figure A.2-8

Site Sketch of CAS 09-34-01, Underground Detection Station 


\section{A.3.0 Step 1 - State the Problem}

The problem statement for CAU 139 is: "Existing information on the nature and extent of potential contamination is insufficient to evaluate and recommend corrective action alternatives for the CASs in CAU 139” with the exception of CASs 09-23-01 and 09-34-01. Because no additional information is required to evaluate and recommend corrective actions for CASs 09-23-01 and 09-34-01, DQOs (to control the type, quantity, and quality of data to be gathered during the CAI) for these CASs will not be developed.

\section{A.3.1 Planning Team Members}

The DQO planning team consists of representatives from NDEP, NNSA/NSO, SNJV, and BN. The primary decision makers are the NDEP and NNSA/NSO representatives. Table A.3-1 lists representatives from each organization in attendance for the January 4, 2006, DQO meeting.

Table A.3-1

Final DQO Meeting Participants for CAU 139 January 4, 2006

\begin{tabular}{||c|l||}
\hline Participant & \multicolumn{1}{|c|}{ Affiliation } \\
\hline \hline Ted Zaferatos & Nevada Division of Environmental Protection \\
\hline Sabine Curtis & $\begin{array}{l}\text { U.S. Department of Energy, National Nuclear Security Administration } \\
\text { Nevada Site Office }\end{array}$ \\
\hline David Nacht & Bechtel Nevada \\
\hline Tom Thiele & Bechtel Nevada \\
\hline Robert Boehlecke & Stoller-Navarro Joint Venture \\
\hline Grant Evenson & Stoller-Navarro Joint Venture \\
\hline Steve Felton & Stoller-Navarro Joint Venture \\
\hline Christian Palay & Stoller-Navarro Joint Venture \\
\hline Jeff Kirkwood & Stoller-Navarro Joint Venture \\
\hline C.-H. Tung & Stoller-Navarro Joint Venture \\
\hline Joe Hutchinson & Stoller-Navarro Joint Venture \\
\hline Arno Gomez & Stoller-Navarro Joint Venture \\
\hline Joe Peters & Stoller-Navarro Joint Venture \\
\hline
\end{tabular}




\section{A.3.2 Conceptual Site Model}

The CSM is used to organize and communicate information about site characteristics. It reflects the best interpretation of available information at any point in time. The CSM is a primary vehicle for communicating assumptions about release mechanisms, potential migration pathways, or specific constraints. It provides a good summary of how and where contaminants are expected to move and what impacts such movement may have. It is the basis for assessing how contaminants could reach receptors both in the present and future. The CSM describes the most probable scenario for current conditions at each site and define the assumptions that are the basis for identifying appropriate sampling strategy and data collection methods. Accurate CSMs are important as they serve as the basis for all subsequent inputs and decisions throughout the DQO process.

The CSM was developed for CAU 139 using information from the physical setting, potential contaminant sources, release information, historical background information, knowledge from similar sites, and physical and chemical properties of the potentially affected media and COPCs.

The CSM consists of:

- Potential contaminant releases including media subsequently affected.

- $\quad$ Release mechanisms (the conditions associated with the release).

- Potential contaminant source characteristics including contaminants suspected to be present and contaminant-specific properties.

- Site characteristics including physical, topographical, and meteorological information.

- Migration pathways and transport mechanisms that describe the potential for migration and where the contamination may be transported.

- The locations of points of exposure where individuals or populations may come in contact with a COC associated with a CAS.

- Routes of exposure where contaminants may enter the receptor.

If additional elements are identified during the investigation that are outside the scope of the CSM, the situation will be reviewed and a recommendation will be made as to how to proceed. In such 
cases, NDEP and NNSA/NSO will be notified and given the opportunity to comment on, or concur with, the recommendation.

The applicability of the CSM as it applies to each CAS is summarized in Table A.3-2 and discussed below. Table A.3-2 provides information on CSM elements that will be used throughout the remaining steps of the DQO process. Figure A.3-1 represents site conditions applicable to this CSM.

\section{A.3.2.1 Contaminant Release}

The most likely locations of the contamination and releases to the environment are the soils directly below or adjacent to the CSM's surface and subsurface source components (e.g.., burnpits, waste storage sites, waste trenches, etc.). The CSM accounts for potential releases resulting from the placement of wastes or contamination of environmental media from operational sources. Any contaminants migrating from CASs, regardless of physical or chemical characteristics, are expected to exist at interfaces, and in the soil adjacent to disposal features in lateral and vertical directions.

\section{A.3.2.2 Potential Contaminants}

The COPCs applicable to Decision I environmental samples from each of the CASs of CAU 139 are defined as the analytes reported from the analytical methods stipulated in Table A.3-3. The list of COPCs is intended to encompass all of the contaminants that could potentially be present at each CAS. These contaminants were identified during the planning process through the review of site history, process knowledge, personal interviews, past investigation efforts (where available), and inferred activities associated with the CASs. Because complete information regarding activities performed at the CAU 139 sites is not available, contaminants detected at similar NTS sites were included in the contaminant lists to reduce the uncertainty.

During the review of site history documentation, process knowledge information, personal interviews, past investigation efforts (where available), and inferred activities associated with the CASs, some of the COPCs were identified as targeted contaminants at specific CASs. Targeted contaminants are those COPCs for which evidence in the available site and process information suggests that they may be reasonably suspected to be present at a given CAS. The targeted contaminants are required to meet a more stringent completeness criteria than other COPCs thus 
Table A.3-2

\section{Conceptual Site Model}

Description of Elements for Each CAS in CAU 139

\begin{tabular}{|c|c|c|c|c|c|c|c|}
\hline CAS Identifier & 03-35-01 & 04-08-02 & 04-99-01 & $06-19-02$ & $06-19-03$ & $09-23-01$ & $09-34-01$ \\
\hline CAS Description & Burn Pit & $\begin{array}{l}\text { Waste } \\
\text { Disposal } \\
\text { Site }\end{array}$ & $\begin{array}{c}\text { Contaminated } \\
\text { Surface } \\
\text { Debris }\end{array}$ & $\begin{array}{c}\text { Waste } \\
\text { Disposal } \\
\text { Site/Burn Pit }\end{array}$ & $\begin{array}{c}\text { Waste } \\
\text { Disposal } \\
\text { Trenches }\end{array}$ & $\begin{array}{c}\text { Area } 9 \\
\text { Gravel Gertie }\end{array}$ & $\begin{array}{c}\text { Under- } \\
\text { ground } \\
\text { Detection } \\
\text { Station }\end{array}$ \\
\hline Site Status & \multicolumn{7}{|c|}{ Sites are inactive and/or abandoned } \\
\hline Future Land Use & \multicolumn{7}{|c|}{ Occasional Use Area - 80 hours (10 days) per year } \\
\hline $\begin{array}{c}\text { Sources of } \\
\text { Potential Soil } \\
\text { Contamination }\end{array}$ & $\begin{array}{l}\text { Accelerants, } \\
\text { debris }\end{array}$ & \multicolumn{2}{|c|}{ Surface debris } & $\begin{array}{l}\text { Accelerants, } \\
\text { debris }\end{array}$ & $\begin{array}{l}\text { Buried } \\
\text { wastes }\end{array}$ & $\begin{array}{l}\text { Conventional } \\
\text { explosives }\end{array}$ & None \\
\hline $\begin{array}{c}\text { Location of } \\
\text { Contamination/ } \\
\text { Release Point }\end{array}$ & \multicolumn{4}{|c|}{ Land surface } & $\begin{array}{l}\text { Base of } \\
\text { trench(es) }\end{array}$ & $\begin{array}{l}\text { Gravel } \\
\text { gertie }\end{array}$ & None \\
\hline $\begin{array}{c}\text { Amount } \\
\text { Released }\end{array}$ & \multicolumn{5}{|c|}{ Unknown } & Not Available & None \\
\hline Affected Media & \multicolumn{7}{|c|}{ Soil } \\
\hline $\begin{array}{c}\text { Potential } \\
\text { Contaminants }\end{array}$ & $\begin{array}{c}\text { VOCs, } \\
\text { SVOCs, } \\
\text { TPH-DRO, } \\
\text { PCBs, } \\
\text { RCRA } \\
\text { metals, } \\
\text { beryllium, } \\
\text { radionuclides }\end{array}$ & \multicolumn{2}{|c|}{ Radionuclides, PCBs } & $\begin{array}{c}\text { VOCS, } \\
\text { SVOCs, } \\
\text { TPH-DRO, } \\
\text { PCBs, } \\
\text { pesticides, } \\
\text { RCRA } \\
\text { metals, } \\
\text { beryllium, } \\
\text { radionuclides }\end{array}$ & $\begin{array}{c}\text { VOCs, } \\
\text { SVOCs, } \\
\text { TPH-DRO, } \\
\text { PCBs, RCRA } \\
\text { metals, } \\
\text { beryllium, } \\
\text { radionuclides }\end{array}$ & $\begin{array}{l}\text { Uranium and } \\
\text { daughter } \\
\text { products }\end{array}$ & None \\
\hline $\begin{array}{c}\text { Transport } \\
\text { Mechanisms }\end{array}$ & \multicolumn{6}{|c|}{$\begin{array}{l}\text { Percolation of precipitation through subsurface media serves as the major driving force for } \\
\text { migration of contaminants. Surface water runoff may provide for the transportation of some } \\
\text { contaminants within or outside of the footprints of the CASs. }\end{array}$} & None \\
\hline $\begin{array}{l}\text { Migration } \\
\text { Pathways }\end{array}$ & \multicolumn{6}{|c|}{ Vertical transport expected to dominate over lateral transport due to small surface gradients. } & None \\
\hline $\begin{array}{l}\text { Lateral and } \\
\text { Vertical Extent } \\
\text { of } \\
\text { Contamination }\end{array}$ & \multicolumn{6}{|c|}{$\begin{array}{l}\text { Contamination, if present, is expected to be contiguous to the release points. Concentrations } \\
\text { are expected to decrease with distance and depth from the source. Groundwater contamination } \\
\text { is not expected. Lateral and vertical extent of contaminant of concern contamination is } \\
\text { assumed to be within the spatial boundaries. }\end{array}$} & $\mathrm{N} / \mathrm{A}$ \\
\hline $\begin{array}{l}\text { Exposure } \\
\text { Scenario }\end{array}$ & \multicolumn{7}{|c|}{$\begin{array}{l}\text { The potential for contamination exposure is limited to industrial workers, construction workers, and military } \\
\text { personnel conducting training. These human receptors may be exposed to contaminants of potential concern } \\
\text { through oral ingestion, inhalation, dermal contact (absorption) of soil and/or debris due to inadvertent } \\
\text { disturbance of these materials or irradiation by radioactive materials. }\end{array}$} \\
\hline
\end{tabular}

DRO = Diesel-range organics

$\mathrm{kg}=$ Kilogram

N/A = Not applicable

$\mathrm{PCBs}=$ Polychlorinated biphenyls
RCRA = Resource Conservation and Recovery Act

SVOC = Semivolatile organic compound

$\mathrm{TPH}=$ Total petroleum hydrocarbons

VOC $=$ Volatile organic compound 


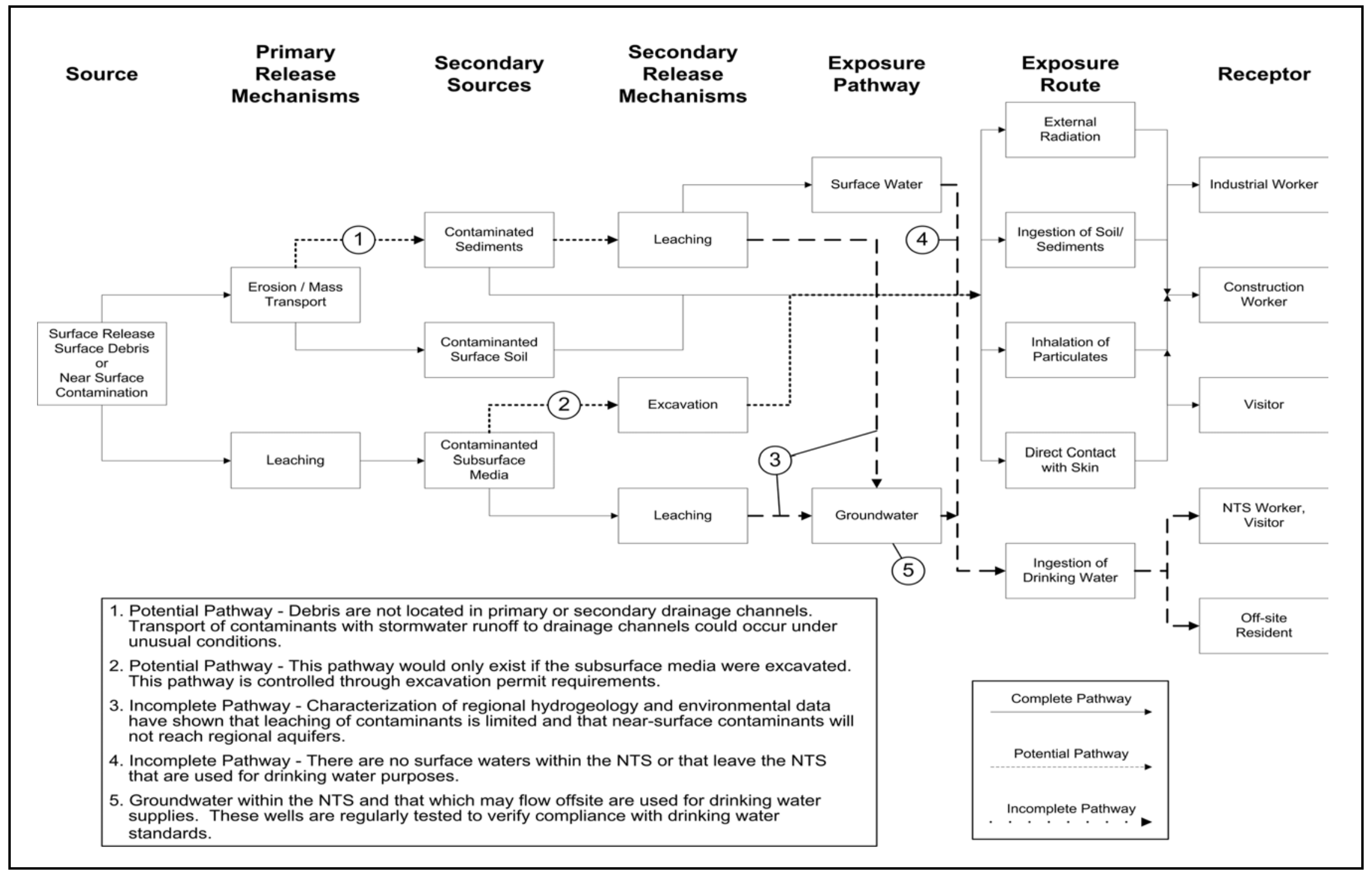

Figure A.3-1

Corrective Action Unit 139 Conceptual Site Model 
Table A.3-3

Analytical Program ${ }^{\mathrm{a}}$

(Includes Waste Characterization Analyses)

\begin{tabular}{|c|c|c|c|c|c|}
\hline Analyses $^{\mathrm{b}}$ & $\begin{array}{l}\text { 우 } \\
\text { ம் } \\
\text { mै } \\
\text { लூ }\end{array}$ & $\begin{array}{l}\text { No } \\
\text { do } \\
\text { ờ } \\
\text { dे }\end{array}$ & 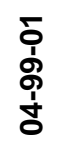 & $\begin{array}{l}\text { ò } \\
\text { ò } \\
\stackrel{1}{+} \\
\dot{0}\end{array}$ & $\begin{array}{l}\text { m } \\
\text { ó } \\
\stackrel{1}{+} \\
\dot{0}\end{array}$ \\
\hline \multicolumn{6}{|c|}{ Organic Contaminants of Potential Concern (COPCs) } \\
\hline Volatile Organic Compounds ${ }^{c}$ & $\mathrm{X}$ & $\mathrm{N} / \mathrm{A}$ & $\mathrm{X}$ & $\mathrm{X}$ & $\mathrm{X}$ \\
\hline Semivolatile Organic Compounds ${ }^{c}$ & $\mathrm{X}$ & $\mathrm{N} / \mathrm{A}$ & $\mathrm{X}$ & $\mathrm{X}$ & $\mathrm{X}$ \\
\hline Total Petroleum Hydrocarbons-Diesel-Range Organics & $\mathrm{X}$ & $\mathrm{N} / \mathrm{A}$ & $\mathrm{X}$ & $\mathrm{X}$ & $\mathrm{X}$ \\
\hline Polychlorinated Biphenyls & $\mathrm{X}$ & $X$ & $\mathrm{X}$ & $X$ & $X$ \\
\hline Pesticides & $\mathrm{N} / \mathrm{A}$ & $\mathrm{N} / \mathrm{A}$ & N/A & $\mathrm{X}$ & N/A \\
\hline \multicolumn{6}{|c|}{ Inorganic COPCs } \\
\hline $\begin{array}{c}\text { Total Resource Conservation and Recovery Act Metals, } \\
\text { Beryllium }{ }^{c}\end{array}$ & $X$ & $\mathrm{~N} / \mathrm{A}$ & $X$ & $X$ & $\mathrm{X}$ \\
\hline \multicolumn{6}{|c|}{ Radionuclide COPCs } \\
\hline Gamma Spectroscopy $^{d}$ & $\mathrm{X}$ & $\mathrm{X}$ & $\mathrm{X}$ & $\mathrm{X}$ & $\mathrm{X}$ \\
\hline Isotopic Uranium, Isotopic Plutonium, Strontium-90 & $\mathrm{N} / \mathrm{A}$ & $\mathrm{X}$ & $\mathrm{X}$ & $\mathrm{N} / \mathrm{A}$ & $\mathrm{X}$ \\
\hline Tritium & $\mathrm{N} / \mathrm{A}$ & $N / A$ & N/A & N/A & $X$ \\
\hline
\end{tabular}

$X=$ Required analytical method

N/A = Not applicable

${ }^{a}$ The contaminants of potential concern are the analytes reported from the analytical methods listed. ${ }^{b}$ If the volume of material is limited, prioritization of the analyses will be necessary.

'May also include Toxicity Characteristic Leaching Procedure analytes if sample is collected for waste management purposes.

${ }^{\mathrm{d}}$ Results of gamma analysis will be used to determine whether further radioanalytical analysis is warranted.

providing greater protection against a decision error (see Section A.3.2). Corrective action

unit 139 CASs with targeted analytes are listed in Table A.3-4. Corrective action site 04-08-02 is the only CAS with a targeted analyte based on process knowledge.

Table A.3-4

Targeted Analytes for CAU 139

\begin{tabular}{|c|c|c|}
\hline CAS & $\begin{array}{c}\text { Chemical } \\
\text { Targeted Analyte(s) }\end{array}$ & $\begin{array}{c}\text { Radiological } \\
\text { Targeted Analyte(s) }\end{array}$ \\
\hline \hline $04-08-02$ & N/A & Cesium-137 \\
\hline N/A = Not applicable
\end{tabular}




\section{A.3.2.3 Contaminants of Concern at Area 9 CASs}

Corrective Action Sites 09-23-01 and 09-34-01 will not be investigated because sufficient information has already been collected to make a decision regarding closure alternatives. The COCs at CAS 09-23-01 were generated as a result of the Ganymede safety experiment detonated within the gravel gertie. The safety experiment was a zero-yield test that dispersed uranium and daughter isotopes into the soil. It is assumed that subsurface radionuclide contamination exists in soils below the gravel gertie.

Corrective Action Site 09-34-01 is an underground bunker/monitoring station where data from surrounding testing were collected. The only access to the bunker is by a vertical elevator shaft. Due to the layout as determined by engineering drawings, along with the lack of soil staining around the elevator shaft exit, it was determined that no COCs are present at this CAS.

\section{A.3.2.4 Contaminant Characteristics}

Contaminant characteristics include, but are not limited to: solubility, density, and adsorption potential. In general, contaminants with low solubility, high affinity for media, and high density can be expected to be found relatively close to release points. Contaminants with small particle size, high solubility, low density, and/or low affinity for media are found further from release points or in low areas where evaporation of ponding will concentrate dissolved contaminants.

\section{A.3.2.5 Site Characteristics}

Site characteristics are defined by the interaction of physical, topographical, and meteorological attributes and properties. Physical properties include permeability, porosity, hydraulic conductivity, degree of saturation, sorting, chemical composition, and organic content. Topographical and meteorological properties and attributes include slope stability, precipitation frequency and amounts, precipitation runoff pathways, drainage channels and ephemeral streams, and evapotranspiration potential. The site characteristics for the CASs are as follows:

- CAS 03-35-01 is located near the intersection of the Mercury Highway and the 7-01 Road (known as the BJY). The northern area of the site has been disturbed by vehicular activity. The site is flat and the area not affected by traffic is well vegetated. 
- CASs 04-08-02 and 04-99-01 are located on the western slopes of the Yucca Valley. The sites slope gently to the east with gravel at the surface. Vegetation typical of the area is present at both sites.

- CASs 06-19-02 and 06-19-03 are located on the floor of the Yucca Valley. The sites are flat with very little vegetation. The surface at CAS 06-19-02 is sandy and fences are present. The surface at CAS 06-19-03 is compacted sand and gravel with a water pipe running along the western edge.

- CAS 09-23-01 is located along the 9-01 Road on the floor of the Yucca Valley. The site is flat with two large piles of gravel and the toe of a berm extending into it. The surface is sandy with little vegetation. A scar from a trench that runs from the north to the south within the site is also present.

- CAS 09-34-01 is located at the northeast corner of the 9-01 Road and old Mercury Highway intersection. A large berm with a concrete station built into the side is present but is not part of the CAS. The surface beyond the berm is compacted sand and gravel with little vegetation.

\section{A.3.2.6 Migration Pathways And Transport Mechanisms}

Migration pathways include the lateral migration of potential contaminants across surface soils/sediments and vertical migration of potential contaminants through subsurface soils.

Stormwater flow events provide an intermittent mechanism for both vertical and horizontal transport of contaminants. Contaminated sediments entrained by these stormwater events would be carried by the streamflow to locations where the flowing water loses energy and the sediments drop out. These locations are readily identifiable by hydrologists as sedimentation areas. The sites within the Yucca Flat slope gently toward the valley floor. Surface waters with entrained sediments congregate in arroyos and deposit sediments in the Yucca Flat.

Infiltration and percolation of precipitation serves as a driving force for downward migration of contaminants. However, due to high potential evapotranspiration (annual potential evapotranspiration at the Area 3 Radiological Waste Management Site has been estimated at 62.6 in. [Shott et al., 1997]) and limited precipitation for this region (6.7 in. per year [ARL/SORD, 2005]), percolation of infiltrated precipitation at the NTS does not provide a significant mechanism for vertical migration of contaminants to groundwater (DOE/NV, 1992). 


\section{A.3.2.7 Exposure Scenarios}

Human receptors may be exposed to COPCs through oral ingestion, inhalation, dermal contact (absorption) of soil or debris due to inadvertent disturbance of these materials or irradiation by radioactive materials. The land use and exposure scenarios for the CAU 139 CASs are listed in Table A.3-5. These are based on NTS current and future land use. Although CAS 06-19-02 and CAS 06-19-03 are located within $1 \mathrm{mi}$ of a currently active area, no facilities are present that would allow these to be used as an assigned work station for NTS site personnel. However, as site personnel may periodically perform work at these sites, they are considered to be occasional use areas.

Corrective Action Sites 03-35-01, 04-08-02, 04-99-01, and 09-23-01 are at remote locations without any site improvements and where no regular work is performed. There is no exposure scenario for CAS 09-34-01 because no contamination is believed to be present. There is still the possibility, however, that site workers could occupy these locations on an occasional and temporary basis. Therefore, these sites are also classified as occasional use areas.

The future land-use scenarios for the CASs in CAU 139 of Nuclear Test Zone and Nuclear and High Explosives Test Zone (DOE/NV, 1998) support these exposure scenarios. The nature of these future land-use zones (nuclear and explosives testing) ensures that future land use will be consistent with current land uses as described in Table A.3-5. 
Table A.3-5

Land-Use and Exposure Scenarios

\begin{tabular}{||c|l|l||}
\hline $\begin{array}{c}\text { Corrective } \\
\text { Action } \\
\text { Site }\end{array}$ & \multicolumn{1}{|c|}{ Record of Decision Land-Use Zone } & \multicolumn{1}{c|}{ Exposure Scenario } \\
\hline \hline $03-35-01$, & $\begin{array}{l}\text { Nuclear and High Explosives Test } \\
\text { This area is designated within the } \\
\text { Nuclear Test Zone for additional } \\
\text { underground nuclear weapons tests and } \\
\text { outdoor high-explosive tests. This zone } \\
\text { includes compatible defense and } \\
\text { nondefense research, development, and } \\
\text { testing activities. }\end{array}$ & $\begin{array}{l}\text { Occasional Use Area } \\
\text { Worker will be exposed to the site occasionally } \\
\text { (up to 80 hours per year for 5 years). Site } \\
\text { structures are not present for shelter and comfort } \\
\text { of the worker. }\end{array}$ \\
\hline $06-19-02$, & $\begin{array}{l}\text { Nuclear Test } \\
\text { This area is reserved for dynamic } \\
\text { experiments, hydrodynamic tests, and } \\
\text { underground nuclear weapons and } \\
09-23-01,\end{array}$ & $\begin{array}{l}\text { Occasional Use Area } \\
\text { Worker will be exposed to the site occasionally } \\
\text { (up to 80 hours per year for 5 years). Site } \\
\text { structures are not present for shelter and comfort } \\
\text { of the workers. }\end{array}$ \\
& $\begin{array}{l}\text { weapons effects tests. This zone } \\
\text { includes compatible defense and } \\
\text { nondefense research, development and } \\
\text { testing activities. }\end{array}$ & \\
\hline
\end{tabular}




\section{A.4.0 Step 2 - Identify the Decisions}

Step 2 of the DQO process identifies the decision statements and defines appropriate alternative actions that may be taken, depending on the answer to the decision statements.

\section{A.4.1 Decision Statements}

The Decision I statement is: “Is any COC present in environmental media within the CAS?” Any analytical result for a COPC above the FAL will result in that COPC being designated as a COC. If a COC is detected, then Decision II must be resolved.

The Decision II statement is: "If a COPC is present, is sufficient information available to evaluate potential corrective action alternatives?” Sufficient information is defined to include:

- Identifying the volume of media containing any COC bounded by analytical sample results in lateral and vertical directions.

- The information needed to characterize IDW for disposal.

- The information needed to determine potential remediation waste types.

If sufficient information is not available to evaluate potential corrective action alternatives, then site conditions will be re-evaluated and additional samples will be collected (as long as the scope of the investigation is not exceeded and any CSM assumption has not been shown to be incorrect).

\section{A.4.2 Alternative Actions to the Decisions}

In this section, the actions that may be taken to solve the problem are identified depending on the possible outcomes of the investigation.

\section{A.4.2.1 Alternative Actions to Decision I}

If no COC associated with a release from the CAS is detected, then further assessment of the CAS is not required. If a COC associated with a release from the CAS is detected, then the extent of COC 
contamination will be determined and additional information required to evaluate potential corrective action alternatives will be collected.

\section{A.4.2.2 Alternative Actions to Decision II}

If sufficient information is available to evaluate potential corrective action alternatives, then further assessment of the CAS is not required. If sufficient information is not available to evaluate potential corrective action alternatives, then additional samples will be collected. 


\section{A.5.0 Step 3 - Identify the Inputs to the Decision}

This step identifies the information needed, determines sources for information, and identifies sampling and analysis methods that will allow reliable comparisons with FALs.

\section{A.5.1 Information Needs}

To resolve Decision I (determine whether a COC is present at a given CAS), samples need to be collected and analyzed following these two criteria: (1) samples must be collected in areas most likely to contain a COC; and (2) the analytical suite selected must be sufficient to identify any COCs present in the samples.

To resolve Decision II (determine whether sufficient information is available to evaluate potential corrective action alternatives at each CAS), samples need to be collected and analyzed to meet the following criteria:

- Samples must be collected in areas contiguous to the contamination, but where contaminant concentrations are below FALs.

- Samples of the waste or environmental media must provide sufficient information to characterize the IDW for disposal.

- Samples of the waste or environmental media must provide sufficient information to determine potential remediation waste types.

- The analytical suites selected must be sufficient to detect contaminants at concentrations equal to or less than their corresponding FALs.

\section{A.5.2 Sources of Information}

Information to satisfy Decision I and Decision II will be generated by collecting environmental samples using grab sampling, hand auguring, backhoe excavation, or other appropriate sampling methods. These samples will be submitted to analytical laboratories meeting the quality criteria stipulated in the Industrial Sites QAPP (NNSA/NV, 2002a). Only validated data from analytical laboratories will be used to make DQO decisions. Sample collection and handling activities will follow standard procedures. 


\section{A.5.2.1 Sample Locations}

Decision I samples must be collected at locations most likely to contain a COC, if present. These locations will be selected based on field-screening techniques, biasing factors, the CSM, and existing information. Analytical suites for Decision I samples will include all COPCs identified in Table A.3-3.

Field-screening techniques may be used to select appropriate sampling locations by providing semiquantitative data that can be used to comparatively select samples to be submitted for laboratory analyses from several screening locations. Field screening may also be used for health and safety monitoring and to assist in making certain health and safety decisions. The following field-screening methods may be used to select analytical samples at CAU 139:

- Volatile organic compounds - A photoionization detector, or an equivalent instrument or method, will be used to conduct headspace analysis at CASs 03-35-01, 04-99-01, 06-19-02, and 06-19-03.

- Walkover surface area radiological surveys - A plastic scintillator has been or will be used over approximately 100 percent of the CAS boundaries, as permitted by terrain and field conditions to detect radiologically elevated areas.

- Alpha and beta/gamma radiation - An NT Technology Electra, or equivalent instrument or method, will be used at all CASs

Biasing factors may also be used to select samples to be submitted for laboratory analyses based on existing site information and site conditions discovered during the investigation. The following factors will also be considered in selecting locations for analytical samples at CAU 139:

- Documented process knowledge on source and location of release (e.g., volume of release)

- Stains: Any spot or area on the soil surface that may indicate the presence of a potentially hazardous liquid. Typically, stains indicate an organic liquid such as an oil has reached the soil, and may have spread out vertically and horizontally.

- Elevated radiation: Any location identified during radiological surveys that had alpha/beta/gamma levels significantly higher than surrounding background soil. 
- Geophysical anomalies: Any location identified during geophysical surveys that had results indicating surface or subsurface materials existed, and were not consistent with the natural surroundings (e.g., buried concrete or metal, surface metallic objects).

- Drums, containers, equipment or debris: Materials of interest that may have been used at, or added to, a location and that may have contained or come in contact with hazardous or radioactive substances at some point during their use.

- Lithology: Locations where variations in lithology (soil or rock) indicate that different conditions or materials exist.

- Preselected areas based on process knowledge of the site: Locations for which information from historical photographs, experience from previous investigations, or interviews suggest that a release of hazardous or radioactive substances may have occurred.

- Preselected areas based on process knowledge of the contaminant(s): Locations that may reasonably have received contamination, selected on the basis of the chemical and/or physical properties of the contaminant(s) in that environmental setting.

- Previous sample results: Locations that may reasonably have been contaminated based upon the results of previous field investigations.

- Experience and data from investigations of similar sites

- Visual indicators such as discoloration, textural discontinuities, disturbance of native soils, or any other indication of potential contamination

- $\quad$ Presence of debris, waste, or equipment

- Odor

- $\quad$ Physical and chemical characteristics of contaminants

- Other biasing factors: Factors not previously defined for the CAI, but become evident once the investigation of the site is under way. Previous sample or screening results

Decision II sample step-out locations will be selected based on the CSM, biasing factors, and existing data. Analytical suites will include those parameters that exceeded FALs (i.e., COCs) in prior samples. Biasing factors to support Decision II sample locations include Decision I biasing factors plus available analytical results. 


\section{A.5.2.2 Analytical Methods}

Analytical methods are available to provide the data needed to resolve the decision statements. The analytical methods and laboratory requirements (e.g., detection limits, precision, and accuracy) are provided in Table 3-2 and Table 3-3 along with specific analyses required for the disposal of IDW. 


\section{A.6.0 Step 4-Define the Boundaries of the Study}

The purpose of this step is to define the population of interest, define the spatial boundaries, determine practical constraints on data collection, and define the scale of decision making.

\section{A.6.1 Populations of Interest}

The population of interest to resolve Decision I ("Is any COC present in environmental media within the CAS?”) is any location within the site that is contaminated with any contaminant above a FAL. The populations of interest to resolve Decision II ("If a COC is present, is sufficient information available to evaluate potential corrective action alternatives?”) are:

- Each one of a set of locations bounding contamination in lateral and vertical directions.

- IDW or environmental media that must be characterized for disposal.

- Potential remediation waste.

- Environmental media where natural attenuation or biodegradation or construction/evaluation of barriers is considered.

\section{A.6.2 Spatial Boundaries}

Spatial boundaries are the maximum lateral and vertical extent of expected contamination at each CAS, as shown in Table A.6-1. Contamination found beyond these boundaries may indicate a flaw in the CSM and may require re-evaluation of the CSM before the investigation could continue. Each CAS is considered geographically independent and intrusive activities are not intended to extend into the boundaries of neighboring CASs.

\section{A.6.3 Practical Constraints}

Other NTS activities may affect the ability to investigate this site. Underground utilities may exist at the site, which may limit intrusive sampling locations. Other practical constraints include rough terrain and access restrictions. Access restrictions include scheduling conflicts active on the NTS with other entities, areas posted as contamination areas requiring appropriate work controls, the 
Table A.6-1

Spatial Boundaries of CAU 139 CASs

\begin{tabular}{|c|l|}
\hline \multicolumn{1}{|c|}{ Corrective Action Site } & \multicolumn{1}{c|}{ Spatial Boundaries } \\
\hline \hline $03-35-01$ & $200 \mathrm{ft}$ laterally, 17 ft vertically from debris or anomaly \\
\hline $04-08-02$ & $200 \mathrm{ft}$ laterally outside of CAS boundary, $17 \mathrm{ft}$ vertically \\
\hline $04-99-01$ & $200 \mathrm{ft}$ laterally outside of CAS boundary, $17 \mathrm{ft}$ vertically \\
\hline $06-19-02$ & $200 \mathrm{ft}$ laterally outside of CAS boundary, $17 \mathrm{ft}$ vertically \\
\hline $06-19-03$ & $\begin{array}{l}200 \mathrm{ft} \text { laterally beyond trench boundary, area between trenches, } \\
17 \mathrm{ft} \text { vertically }\end{array}$ \\
\hline
\end{tabular}

water line at CAS 06-19-03, physical barriers (e.g., fences, buildings, steep slopes), and areas requiring authorized access. Additionally, if the CAS 06-19-03 geophysical survey results detect additional trenches, the spacing between adjacent trenches may limit the scope of excavation sampling. Underground utilities surveys will be conducted at each CAS before the start of investigation activities to determine whether utilities exist, and, if so, determine the limit of spatial boundaries for intrusive activities.

\section{A.6.4 Define the Scale of Decision Making}

The scale of decision making in Decision I is defined as the CAS. Any COC detected at any location within the CAS will cause the determination that the CAS is contaminated and needs further evaluation. The scale of decision making for Decision II is defined as a contiguous area contaminated with any COC originating from the CAS. Resolution of Decision II requires this contiguous area to be bounded laterally and vertically. 


\section{A.7.0 Step 5 - Develop a Decision Rule}

This step develops a decision rule (“If..., then...”) statement that defines the conditions under which possible alternative actions will be chosen. In this step, we specify the statistical parameters that characterizes the population of interest, specify the FALs, confirm that detection limits are capable of detecting FALs, and present decision rules.

\section{A.7.1 Population Parameters}

Each sample result representing each population of interest defined in Step 4 will be compared to the action levels to determine the appropriate resolution to Decision I and Decision II. For the Decision I population of interest, a single analytical sample result above FALs would cause a determination that a COC is present within the CAS. For the Decision II population of interest, a single analytical sample result above FALs would cause a determination that the contamination is not bounded in one direction.

Because this approach does not use a statistical average for comparison to the FALs, but rather a point-by-point comparison, the population parameter for both populations of interest is the observed concentration of each analyte from individual analytical sample results.

\section{A.7.2 Decision Rules}

The decision rules applicable to both Decision I and Decision II are:

If COC contamination is inconsistent with the CSM or extends beyond the spatial boundaries identified in Section A.6.2, then work will be suspended and the investigation strategy will be reconsidered. If a COC is present, is consistent with the CSM, and is within spatial boundaries, then the decision will be to continue sampling to define the extent.

The decision rules for Decision I are:

If the population parameter (the observed concentration of each analyte) of any COPC in the Decision I population of interest (defined in Step 4) exceeds the corresponding FAL, then that 
contaminant is identified as a COC, and Decision II samples will be collected. If all COPC concentrations are less than the corresponding FALs, then the decision will be no further action.

The decision rules for Decision II are:

If the population parameter (the observed concentration of any COC) in the Decision II population of interest (defined in Step 4) exceeds the corresponding FAL, then additional samples will be collected to complete the Decision II evaluation. If all bounding COC concentrations are less than the corresponding FALs, then the decision will be that the extent of contamination has been defined in the corresponding lateral and/or vertical direction.

If valid analytical results are available for the waste characterization samples defined in Section A.9.0, then the decision will be that sufficient information exists to characterize the IDW for disposal, determine potential remediation waste types, and to evaluate the feasibility of remediation alternatives.

\section{A.7.3 Action Levels}

The PALs presented in this section are to be used for site screening purposes. They are not necessarily intended to be used as cleanup action levels or FALs. However, they are useful in screening out contaminants that are not present in sufficient concentrations to warrant further evaluation and, therefore, streamline the consideration of remedial alternatives. The process that will be used to move from PALs to FALs is that specified by NAC 445A (NAC, 2004). This regulation stipulates that determination of FALs shall be established by an evaluation of the site based on the risk it poses to public health and the environment. This evaluation will be conducted using Method E1739-95, adopted by the ASTM (ASTM, 1995). The ASTM's RBCA process is summarized in Section 3.3. The Tier I action levels for Decision I and Decision II are the PALs defined below and in Section 3.3. If necessary, a Tier 2 or Tier 3 evaluation will be conducted by calculating SSTLs. If a Tier 2 or Tier 3 evaluation is conducted for TPH, the hazardous constituents of TPH will be compared to the SSTLs, as the general measure of TPH provides insufficient information about the amounts of individual COCs within the TPH measurement. 
The comparison of laboratory results to FALs and the evaluation of potential corrective actions will be included in the investigation report. The FALs will be defined (along with the basis for their definition) in the investigation report.

\section{A.7.3.1 Chemical PALs}

Except as noted herein, the chemical PALs are defined as the EPA Region 9 PRGs for chemical contaminants in industrial soils (EPA, 2004). Background concentrations for RCRA metals and zinc will be used instead of PRGs when natural background concentrations exceed the PRG, as is often the case with arsenic on the NTS. Background is considered the mean plus two standard deviations of the mean for sediment samples collected by the Nevada Bureau of Mines and Geology throughout the Nevada Test and Training Range (formerly the Nellis Air Force Range) (NBMG, 1998; Moore, 1999). For detected chemical COPCs without established PRGs that have toxicity and carcinogenicity data listed in the EPA IRIS database (EPA, 2005), the protocol used by the EPA Region 9 in establishing PRGs (or similar) will be used to establish PALs. If used, this process will be documented in the investigation report.

\section{A.7.3.2 Total Petroleum Hydrocarbon PALs}

The PAL for TPH is 100 ppm as listed in NAC 445A.2272 (NAC, 2004).

\section{A.7.3.3 Radionuclide PALs}

The PALs for radiological contaminants (other than tritium) are based on the NCRP Report No. 129 recommended screening limits for construction, commercial, industrial land-use scenarios (NCRP, 1999) scaled to 25 mrem/yr dose constraint (Murphy, 2004) and the generic guidelines for residual concentration of radionuclides in DOE Order 5400.5 (DOE, 1993). These PALs are based on the construction, commercial, and industrial land-use scenario provided in the guidance and are appropriate for the NTS based on future land use scenarios as presented in Section A.3.2. The PAL for tritium is based on the UGTA Project limit of 400,000 pCi/L for discharge of water containing tritium to an infiltration basin/area (NNSA/NV, 2002b). 
Solid media such as concrete and/or structures may pose a potential radiological exposure risk to site workers if contaminated. The radiological PAL for solid media will be defined as the unrestricted-release criteria defined in the NV/YMP RadCon Manual (NNSA/NSO, 2004).

\section{A.7.4 Measurement and Analysis Sensitivity}

The measurement and analysis methods listed in Section A.5.2.2 and in the Industrial Sites QAPP (NNSA/NV, 2002a) are capable of measuring contaminant concentrations at or below the corresponding FALs for each COPC. See Section 6.2.8 for additional details. 


\section{A.8.0 Step 6 - Tolerable Limits on Decision Errors}

The purpose of this step is to specify performance criteria for the decision rule. Setting tolerable limits on decision errors requires the planning team to weigh the relative effects of threat to human health and the environment, expenditure of resources, and consequences of an incorrect decision. Section 7.1 of the EPA QA/G-4HW guidance states that if judgmental sampling approaches are used, quantitative statements about data quality will be limited to measurement error (EPA, 2000a).

Measurement error is influenced by imperfections in the measurement and analysis system. Random and systematic measurement errors are introduced in the measurement process during physical sample collection, sample handling, sample preparation, sample analysis, and data reduction. If measurement errors are not controlled they may lead to errors in making the DQO decisions.

This section provides an assessment of the possible outcomes of DQO decisions and the impact of those outcomes if the decisions are in error.

The baseline condition (i.e., null hypothesis) and alternative condition for Decision I are:

- $\quad$ Baseline condition - A COC is present.

- Alternative condition - A COC is not present.

The baseline condition (i.e., null hypothesis) and alternative condition for Decision II are as follows:

- $\quad$ Baseline condition - The extent of a COC has not been defined.

- Alternative condition - The extent of a COC has been defined.

Decisions and/or criteria have false negative or false positive errors associated with their determination. The impact of these decision errors and the methods that will be used to control these errors are discussed in the following subsections. In general terms, confidence in DQO decisions based on judgmental sampling results will be established qualitatively by:

- The development of and concurrence of CSMs (based on process knowledge) by stakeholder participants during the DQO process. 
- Testing the validity of conceptual site models based on investigation results.

- Evaluating the quality of the data based on DQI parameters.

\section{A.8.1 False Negative Decision Error}

The false negative decision error would mean deciding that a COC is not present when it actually is (Decision I), or deciding that the extent of a COC has been defined when it has not (Decision II). In both cases the potential consequence is an increased risk to human health and the environment.

The false negative decision error (where consequences are more severe) is controlled by meeting these criteria:

1. For Decision I, having a high degree of confidence that the sample locations selected will identify COCs if present anywhere within the CAS. For Decision II, having a high degree of confidence that the sample locations selected will identify the extent of COCs.

2. Having a high degree of confidence that analyses conducted will be sufficient to detect any COCs present in the samples.

3. Having a high degree of confidence that the dataset is of sufficient quality and completeness.

To satisfy the first criterion, Decision I samples must be collected in areas most likely to be contaminated by COCs (supplemented by random samples where appropriate). Decision II samples must be collected in areas that represent the lateral and vertical extent of contamination (above action levels). The following characteristics must be considered to control decision errors for the first criterion:

- Source and location of release

- Chemical nature and fate properties

- Physical transport pathways and properties

- Hydrologic drivers

These characteristics were considered during the development of the CSMs and selection of sampling locations. The field-screening methods and biasing factors listed in Section A.5.2.1 will be used to further ensure that appropriate sampling locations are selected to meet these criteria. Radiological survey instruments and field-screening equipment will be calibrated and checked in accordance with 
the manufacturer's instructions and approved procedures. The investigation report will present an assessment on the DQI of representativeness that samples were collected from those locations that best represent the populations of interest as defined in Section A.6.1.

To satisfy the second criterion, Decision I samples will be analyzed for the chemical and radiological parameters listed in Section 3.2. Decision II samples will be analyzed for those chemical and radiological parameters that identified unbounded COCs. The DQI of sensitivity will be assessed for all analytical results to ensure that all sample analyses had measurement sensitivities (detection limits) that were less than or equal to the corresponding FALs. If this criterion is not achieved, the affected data will be assessed (for usability and potential impacts on meeting site characterization objectives) in the investigation report.

To satisfy the third criterion, the entire dataset, as well as individual sample results, will be assessed against the DQIs of precision, accuracy, comparability, and completeness as defined in the Industrial Sites QAPP (NNSA/NV, 2002a) and in Section 6.2.2. The DQIs of precision and accuracy will be used to assess overall analytical method performance as well as to assess the need to potentially “flag” (qualify) individual contaminant results when corresponding QC sample results are not within the established control limits for precision and accuracy. Data qualified as estimated for reasons of precision or accuracy may be considered to meet the constituent performance criteria based on an assessment of the data. The DQI of completeness will be assessed to ensure that all data needs identified in the DQO have been met. The DQI of comparability will be assessed to ensure that all analytical methods used are equivalent to standard EPA methods so that results will be comparable to regulatory action levels that have been established using those procedures. Strict adherence to established procedures and QA/QC protocol protects against false negatives. To provide information for the assessment of the DQIs of precision and accuracy, the following quality control samples will be collected as required by the Industrial Sites QAPP (DOE/NV, 2002a):

- $\quad$ Field duplicates (minimum of 1 per matrix per 20 environmental samples

- Laboratory QC samples (minimum of 1 per matrix per 20 environmental samples or 1 per CAS per matrix, if less than 20 collected) 


\section{A.8.2 False Positive Decision Error}

The false positive decision error would mean deciding that a COC is present when it is not, or a COC is unbounded when it is not, resulting in increased costs for unnecessary sampling and analysis.

The false positive decision error is controlled by implementing all the controls that protect against false negative decision errors. False positive results are typically attributed to laboratory and/or sampling/handling errors that could cause cross contamination. To control against cross contamination, decontamination of sampling equipment will be conducted according to established and approved procedures and only clean sample containers will be used. To determine whether a false positive analytical result may have occurred, the following QC samples will be collected as required by the Industrial Sites QAPP (DOE/NV, 2002a):

- Trip blanks (1 per sample cooler containing VOC environmental samples)

- Equipment blanks (1 per sampling event for each type of decontamination procedure)

- Source blanks (1 per source lot per sampling event)

- Field blanks (minimum of 1 per CAS - additional if field conditions change) 


\section{A.9.0 Step 7 - Optimize the Design for Obtaining Data}

This section provides the general approach for obtaining the information necessary to resolve Decision I and Decision II. A judgmental (nonprobabilistic) sampling scheme will be implemented to select sample locations and evaluate analytical results. Judgmental sampling allows the methodical selection of sample locations that target the populations of interest (defined in Step 4) rather than non-selective random locations.

Because individual sample results, rather than an average concentration, will be used to compare to FALs, statistical methods to generate site characteristics will not be necessary. Section 0.4.4 of the EPA Data Quality Objectives Process for Hazardous Waste Site Investigations (EPA, 2000a) guidance states that the use of statistical methods may not be warranted by program guidelines or site-specific sampling objectives. The need for statistical methods is dependent upon the decisions being made. Section 7.1 of the EPA QA/G-4HW guidance states that a nonprobabilistic (judgmental) sampling design is developed when there is sufficient information on the contamination sources and history to develop a valid CSM and to select specific sampling locations. This design is used to confirm the existence of contamination at specific locations and provide information (such as extent of contamination) about specific areas of the site.

All sample locations will be selected to satisfy the DQI of representativeness in that samples collected from selected locations will best represent the populations of interest as defined in Section A.6.1. To meet this criterion, a biased sampling strategy will be used for Decision I samples to target areas with the highest potential for contamination, if it is present anywhere in the CAS. Sample locations will be determined based on process knowledge, previously acquired data, or the field-screening and biasing factors listed in Section A.5.2.1. If biasing factors are present in soils below locations where Decision I samples were removed, additional Decision I soil samples will be collected at depth intervals selected by the Site Supervisor based on biasing factors to a depth where the biasing factors are no longer present. The Site Supervisor has the discretion to modify the sample locations, but only if the modified locations meet the decision needs and criteria stipulated in this DQO. 
To meet the DQI of representativeness for step-out (Decision II) samples (that Decision II sample locations represent the population of interest as defined in Section A.6.1), sampling locations at each CAS will be selected based on the outer boundary sample locations where COCs were detected, the CSM, and other field-screening and biasing factors listed in Section A.5.2.1. In general, sample locations will be arranged in a triangular pattern around the Decision I location or area at distances based on site conditions, process knowledge, and biasing factors. If COCs extend beyond the initial step-outs, Decision II samples will be collected from incremental step-outs. Initial step-outs will be at least as deep as the vertical extent of contamination defined at the Decision I location and the depth of the incremental step-outs will be based on the deepest contamination observed at all locations. A clean sample (i.e., COCs less than FALs) collected from each step-out direction (lateral or vertical) will define extent of contamination in that direction. The number, location, and spacing of step-outs may be modified by the Site Supervisor, as warranted by site conditions.

The following sections discuss CAS-specific investigation activities, including proposed sample locations. As the sampling strategy for each CAS is developed, specific biasing factors will be described. In the absence of biasing factors, samples will be collected from the default sampling locations described for each CAS.

\section{A.9.1 Corrective Action Site 03-35-01, Burn Pit}

Corrective Action Site 03-35-01 anomalies revealed during the geophysical survey will be (Figure A.2-2) exposed with a backhoe and investigated to identify or rule out the presence of biasing factors around and beneath the anomalies. The scope of the Decision I investigation, including the investigation to expose the geophysical anomalies, will be limited to a 50-ft radius from the site marker and the finished concrete slab to the south.

The soil beneath and surrounding debris (including debris causing a geophysical anomaly) within this area will be inspected and soil samples will be collected if biasing factors are present. One biased location has been identified for sampling based on the presence of burnt debris. This location can be found in the field as a small scorched area approximately 18 in. in diameter. A minimum of one surface soil sample will be collected from 0 to $0.5 \mathrm{ft}$ bgs at this location. All samples will be analyzed to determine whether COCs are present in the soil resulting from point-source contamination. 


\section{A.9.2 Corrective Action Site 04-08-02, Waste Disposal Site}

A biased sampling strategy will be applied to CAS 04-08-02 to target the surface soil areas with the highest potential for contamination (i.e., radiologically elevated areas) resulting from stored material during past operations. Two soil samples will be collected from each of three areas defined by the highest radiological survey results. The three areas are shown in Figure A.9-1. These areas will be field screened for further definition and sample selection based on elevated beta/gamma readings. Proposed locations for collecting Decision I samples are provided on Figure A.9-2.

A minimum of two Decision I soil samples will be collected within each of the three elevated reading locations (shown as polygons based on the Figure A.9-1 radiologically elevated areas). The two samples will be collected from 0 to $0.5 \mathrm{ft}$ bgs. A screening sample will be collected below each sample and submitted for analysis to determine that the biasing factor is decreasing or absent. If a screening sample is not collected, then an additional soil sample will be submitted for analysis from that depth interval.

\section{A.9.3 Corrective Action Site 04-99-01, Contaminated Surface Debris}

The geophysical anomalies at CAS 04-99-01 will be exposed using a backhoe or handtools and investigated to identify or rule out the presence of biasing factors around and beneath the anomalies. Soil samples will be collected at locations where biasing factors are present.

Additionally, the investigation will include excavating a trench perpendicular to the two small mounds and depressions to determine the presence of any debris or biasing factors. This biased sampling strategy targets the areas most likely to encounter any buried debris that may have released COCs into the surrounding soil. A minimum of one sample will be collected from the trench within each mound/depression based on any biasing factors. A screening sample will be collected below each sample submitted for analysis to determine that the biasing factor is decreasing or absent. If a screening sample is not collected, then an additional soil sample will be submitted for analysis from that depth interval. If biasing factors are absent, then sample selection will be from beneath each mound at the interface with undisturbed native material. If the interface with the underlying native soil cannot be discerned, then the sample will be collected at a depth of 0 to $1 \mathrm{ft}$ bgs. The trench will be excavated to a minimum a depth of $1 \mathrm{ft}$ bgs. 


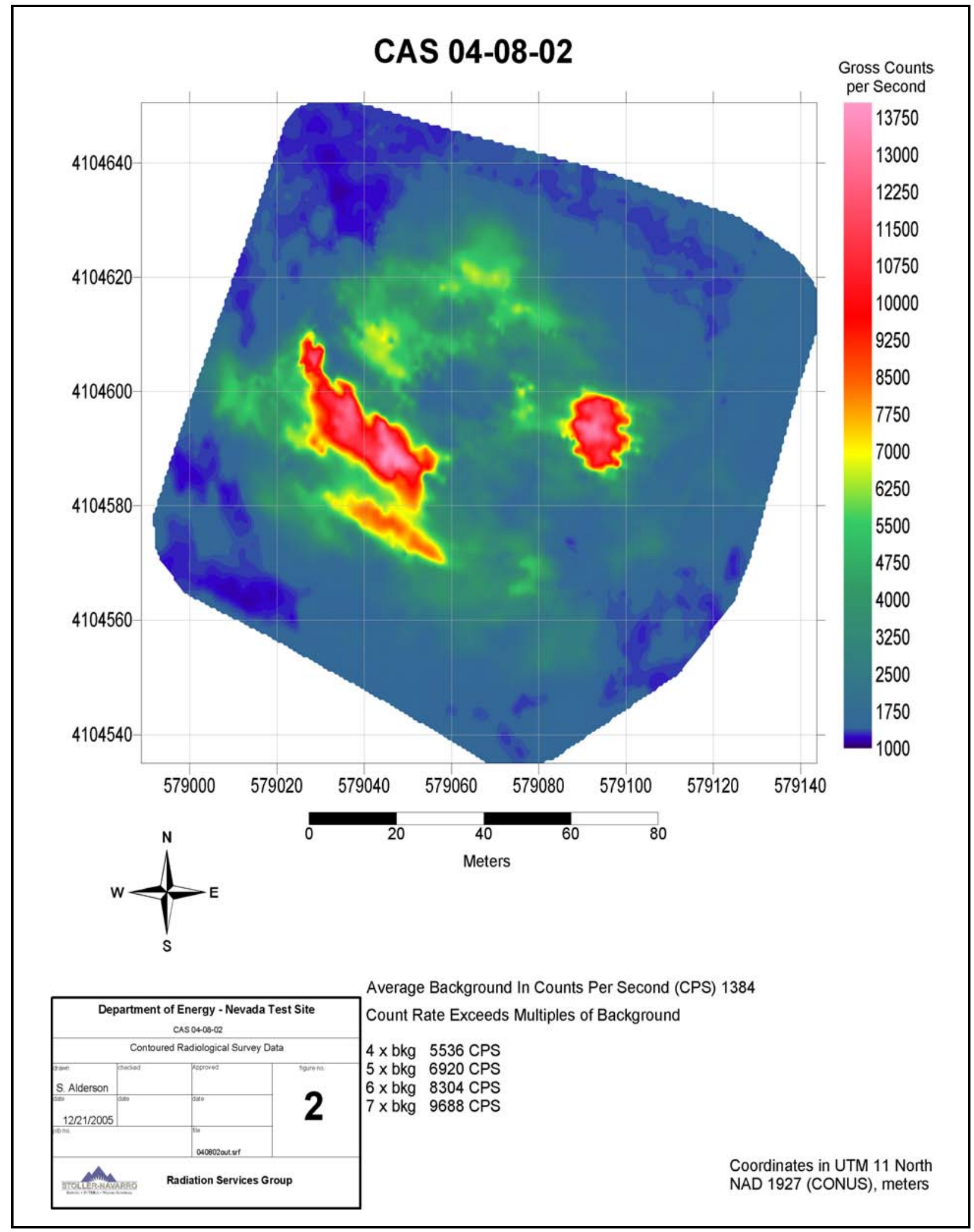

Figure A.9-1

Radiological Survey Results from CAS 04-08-02

\section{Uncontrolled When Printed}




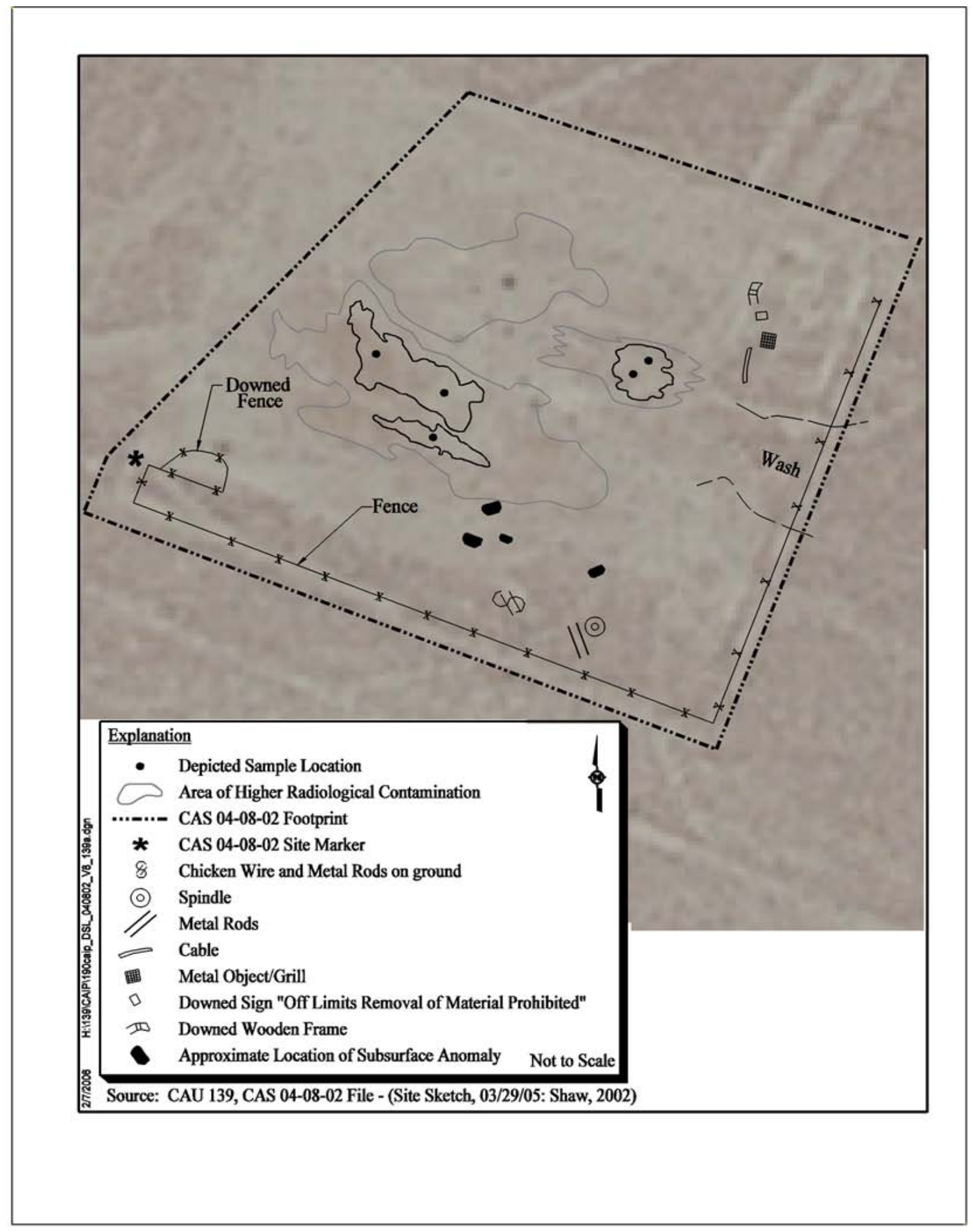

Figure A.9-2

Proposed Sample Locations at CAS 04-08-02 
The cans (surface debris) within this area will also be investigated to determine whether COCs are present within the surface soil resulting from residue deposition that may contribute to point-source contamination. A minimum of one surface sample will be collected from 0 to $0.5 \mathrm{ft}$ bgs of the soil beneath the rusted cans. Additional soil samples will be collected from beneath the cans if biasing factors are present. The proposed sample locations are shown in Figure A.9-3.

\section{A.9.4 Corrective Action Site 06-19-02, Waste Disposal Site/Burn Pit}

A biased sampling strategy will be applied at CAS 06-19-02 in order to target points with the highest potential for contamination in the surface and subsurface soil at three areas within the CAS footprint. The three areas are identified as the round animal pen, the burn pit, and the waste disposal area. These general areas are shown in Figure A.9-4, and a detailed sampling strategy discussion for each area is provided in this section A minimum of two samples from two locations in the round animal pen will be sampled to investigate the potential that COCs may be in the surface soil due to past livestock activity. A minimum of two soil samples will be collected from locations from within a trench excavated to investigate the presence of any debris or burnt residue and to look for the presence of biasing factors. A minimum of two sample locations from beneath the sand at the waste disposal area. The biased sampling strategy targets the areas most likely to encounter any buried debris that may have leaked COCs into the surrounding soil. Soil samples from the trench to be excavated in the waste disposal area may also be collected based upon field observations.

The surface soil in the round animal pen will be investigated to look for biasing factors. Surface soil samples from depths of 0 to $0.5 \mathrm{ft}$ bgs and 1.0 to $1.5 \mathrm{bgs}$ will be collected at two locations exhibiting biasing factors. A minimum of four soil samples will be collected. The proposed sample locations are shown in Figure A.9-4. If no biasing factors are present, the samples will be collected from the center of the animal pen and from a location $2 \mathrm{ft}$ from the perimeter closest to the burn pit.

The investigation at the burn pit will include excavating a trench east to west across the burn pit area. The location of the trench will be determined in the field, and a minimum of one sample will be collected from the trench material beneath each biasing factor. The investigation and trenching will continue to a minimum depth of $5 \mathrm{ft}$ or to a depth where biasing factors are no longer present, whichever is greater. If there is no evidence of past burial activities (i.e., debris) or biasing factors, a 


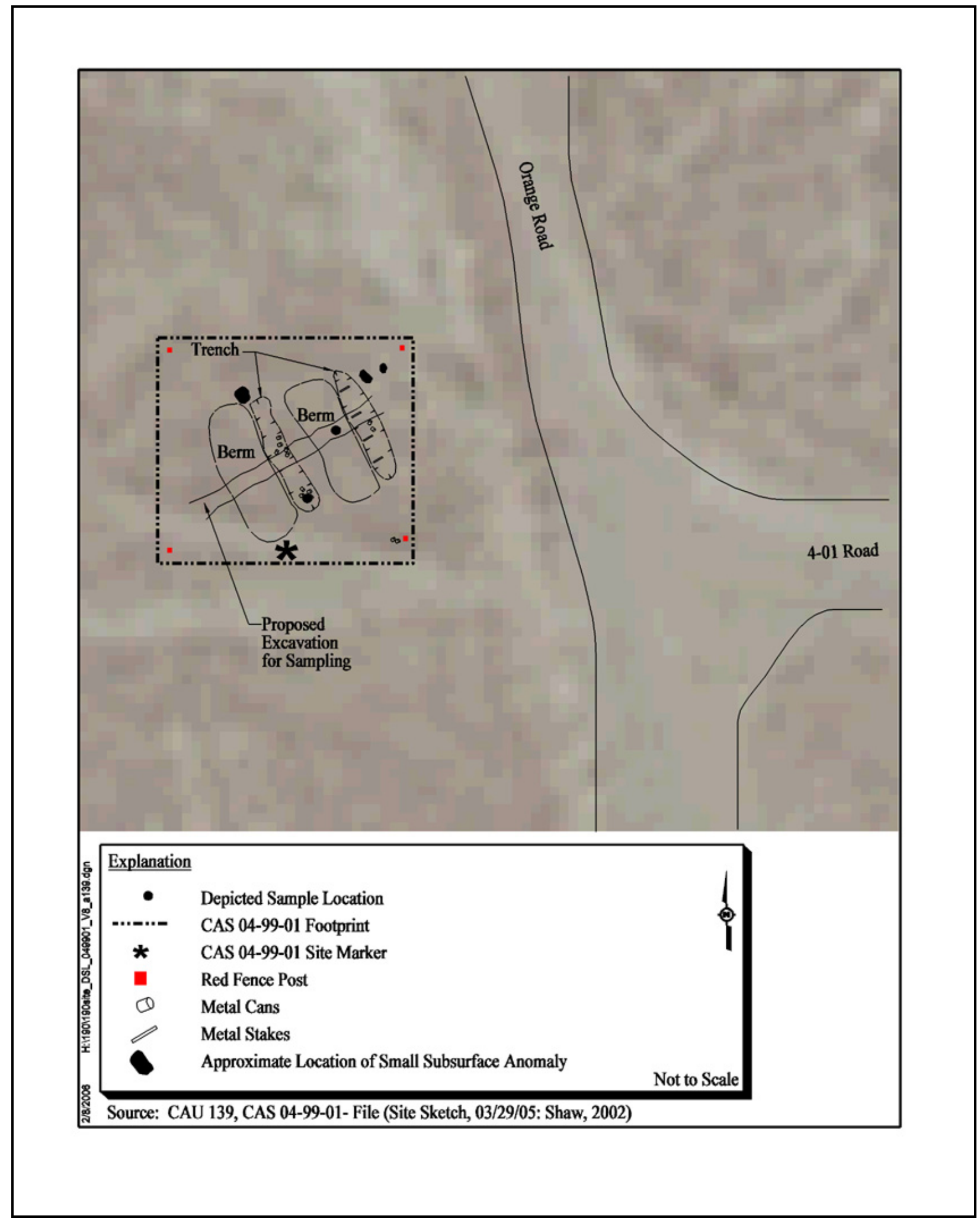

Figure A.9-3

Proposed Sample Locations at CAS 04-99-01 


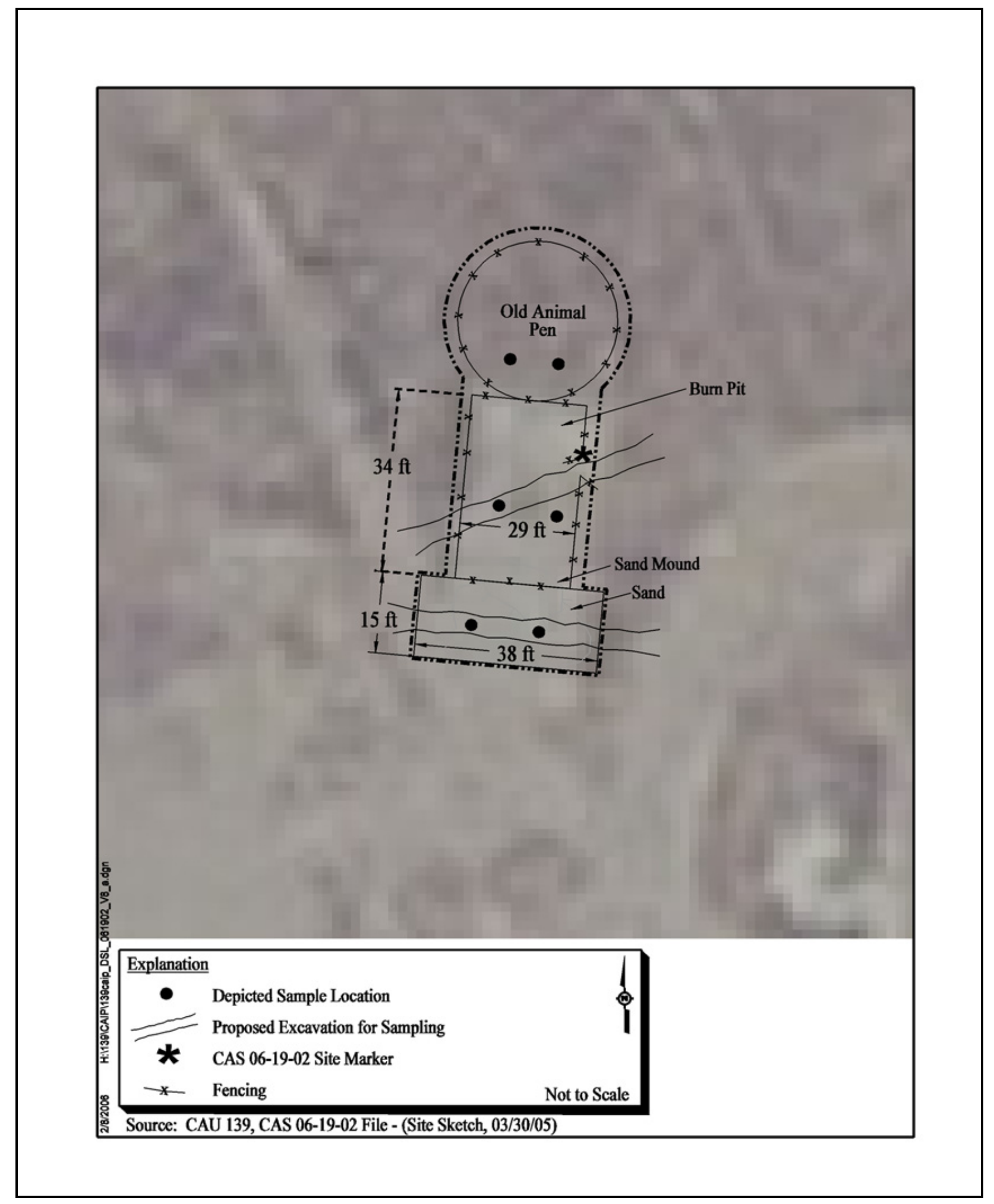

Figure A.9-4

Proposed Sample Locations at CAS 06-19-02 
minimum of two soil samples will be collected from a depth of 2.5 to $3.0 \mathrm{ft}$ bgs from within the trench as shown in Figure A.9-4.

The investigation at the waste disposal area will begin by moving the sand aside to expose the native/historical ground surface beneath the sand. If cannot be discerned, then the interface will be assumed to be at surface grade with the surrounding area. Two soil samples will be collected at an interval from the interface depth to $0.5 \mathrm{ft}$ below it, at locations exhibiting biasing factors, if present. Additionally, the investigation will include excavating a trench across the waste disposal area to a minimum depth of $5 \mathrm{ft}$ below the sand/historical surface interface. A minimum of one sample will be collected from within the trench beneath each potential biasing factor or evidence of debris. The excavation and potential sampling will continue to a depth where biasing factors or debris are no longer present. If there is no evidence of past burial activities (i.e., debris) or biasing factors, a minimum of two soil samples will be collected from the proposed samples locations illustrated in Figure A.9-4.

\section{A.9.5 Corrective Action Site 06-19-03, Waste Disposal Trenches}

Figure A.9-5 provides a map of the past geophysical survey results and shows a distinct anomaly that is assumed to be associated with the burial trenches. This anomaly and the 2004 trench excavation are the only evidence of subsurface burial. A geophysical survey of all scarred areas surrounding the current survey area will be conducted in an effort to identify or rule out the existence of other trenches in the area. This is shown as a blank area in the upper right corner of Figure A.9-5.

If no additional potential trench anomalies are discovered by conducting this expanded geophysical survey, then a minimum of eighteen soil samples will be collected from six sample locations 5 to $10 \mathrm{ft}$ laterally outside the assumed trench perimeter. Figure A.9-6 shows these six proposed sample locations relative to the assumed trench perimeter based on the known anomaly. This set of six locations will function as Decision I locations to bound the perimeter of the CAS trench, or multiple trenches if more trench anomalies are found. If the field investigation determines that other trenches may be present, then other locations in addition to the set of six will be sampled. Sample collection from locations between trenches will be conducted only if the separation is great enough to allow 
excavation without encroaching on the existing trenches. A generalized sampling approach as it relates to depth is provided in the follow paragraph.

In general, three samples will be collected from each sample location: one sample collected from a depth of 2.5 to $3.0 \mathrm{ft}$ bgs, a second sample collected from a depth of 7.5 to $8.0 \mathrm{ft}$ bgs, and a third sample collected from a depth of 12.5 to $13.0 \mathrm{ft}$ bgs. Biasing factors are not expected, but if identified (with the exception of buried waste itself), additional soil samples may be collected. All sampling will remain outside of the boundaries of the trenches. If buried material is encountered, it will not be sampled but placed back into the trench, and a new location will be selected further away from the trench(es). 


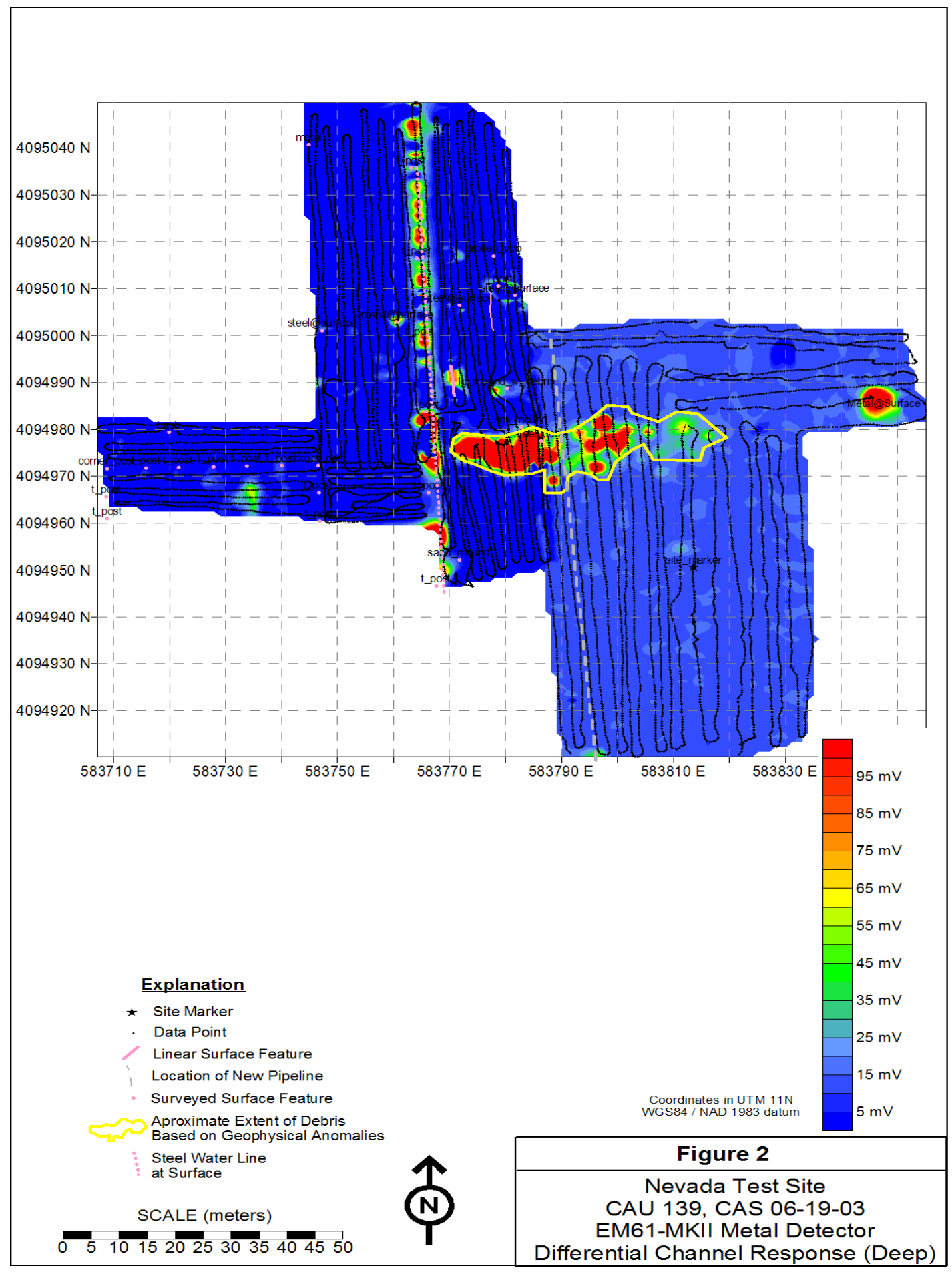

Figure A.9-5

Geophysical Survey from CAS 06-19-03 


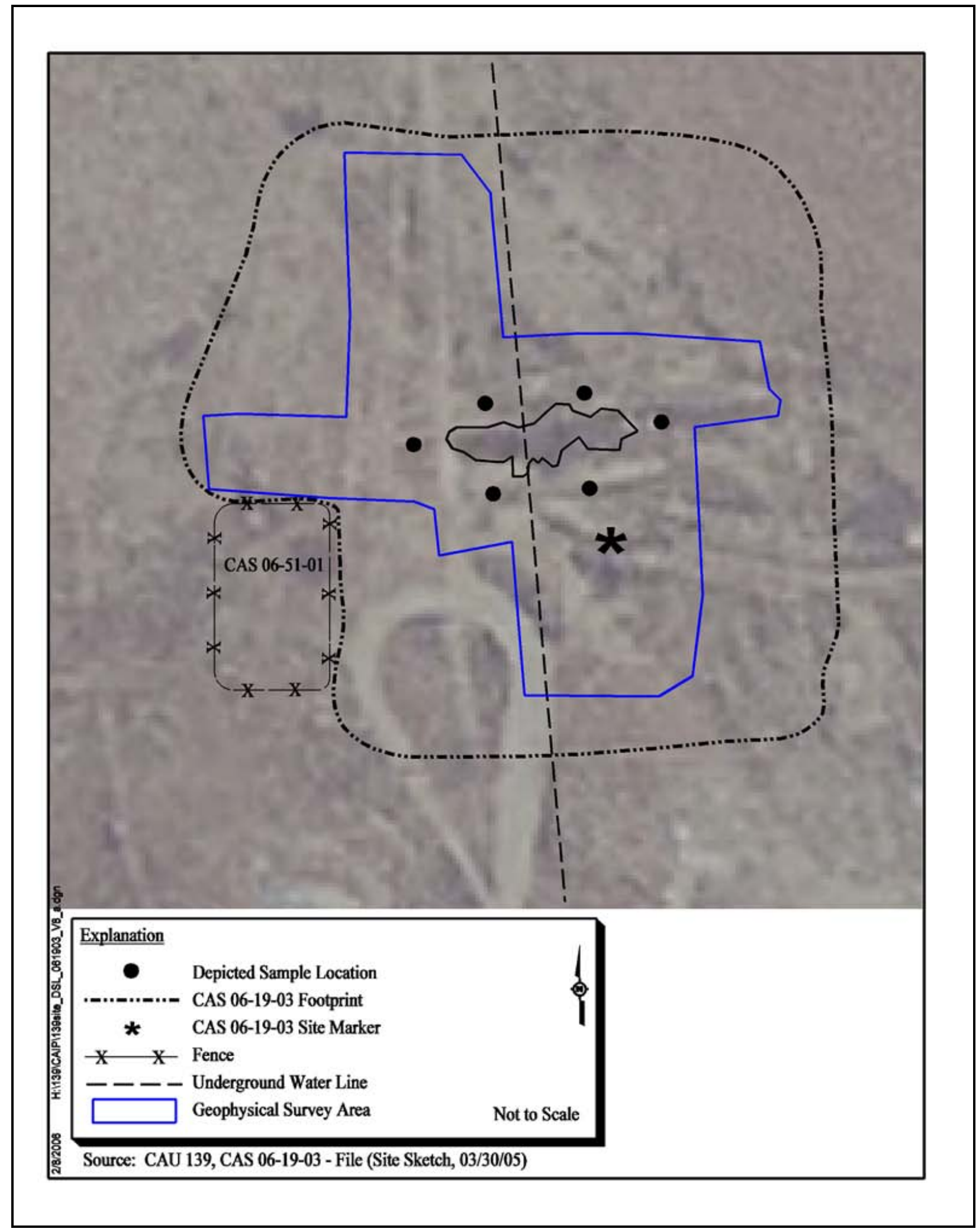

Figure A.9-6

Proposed Sample Locations at CAS 06-19-03 


\section{A.10.0 References}

ARL/SORD, see Air Resources Laboratory./Special Operations and Research Division

ASTM, see American Society for Testing and Materials

Air Resources Laboratory/Special Operations and Research Division, 2005. NTS Climatological Rain Gauge Data web site. As accessed at http://www.sord.nv.doe.gov/home_climate.htm on 20 December 2005

Alderson, S. 2002. Letter from S. Alderson (SNJV) to R. Bull (SAIC) entitled, Radiological Land Area Surveys of 24 Corrective Action Sites (CASs) at the Nevada Test Site, North Las Vegas, NV.

American Society for Testing and Materials. 1995. Standard Guide for Risk-Based Corrective Action Applied at Petroleum Release Sites/American Society for Testing and Materials, ASTM E 1739-95 (Reapproved 2002). Philadelphia, PA.

DOE, see U.S. Department of Energy.

DOE/NV, see U.S. Department of Energy, Nevada Operations Office.

EPA, see U.S. Environmental Protection Agency.

Fahringer, P., Stoller-Navarro Joint Venture. 2005. Memorandum to J. Myers (SNJV) entitled, “CAS 03-35-01 Memorandum of Geophysical Survey Findings.” 22 July. Las Vegas, NV.

IT, see IT Corporation.

IT Corporation. 2001. Radiological Soil Survey of Selected Sites for Preliminary Assessment Geophysical Sites, Fall 2001. Las Vegas, NV.

Moore, J., Science Applications International Corporation. 1999. Memorandum to M Todd (SAIC) entitled, "Background Concentrations for NTS and TTR Soil Samples," 3 February. Las Vegas, NV: IT Corporation.

Murphy, T., Bureau of Federal Facilities. 2004. Letter to R. Bangerter (NNSA/NSO) entitled, "Review of Industrial Sites Project Document Guidance for Calculating Industrial Sites Project Remediation Goals for Radionuclides in Soil Using the Residual Radiation (RESRAD) Computer Code.” 19 November. Las Vegas, NV.

NAC, see Nevada Administrative Code. 
NBMG, see Nevada Bureau of Mines and Geology.

NCRP, see National Council on Radiation Protection and Measurements.

NNSA/NSO, see U.S. Department of Energy, National Nuclear Security Administration Nevada Site Office.

NNSA/NV, see U.S. Department of Energy, National Nuclear Security Administration Nevada Operations Office.

National Council on Radiation Protection and Measurements. 1999. Recommended Screening Limits for Contaminated Surface Soil and Review of Factors Relevant to Site-Specific Studies/National Council on Radiation Protection and Measurements, NCRP Report No. 129. Bethesda, MD.

Nevada Administrative Code. 2004. NAC 445A, “Water Controls.” Carson City, NV. As accessed at http://www.leg.state.nv.us/nac on 20 December 2005.

Nevada Bureau of Mines and Geology. 1998. Mineral and Energy Resource Assessment of the Nellis Air Force Range, Open-File Report 98-1. Reno, NV.

REECo (see Reynolds Electrical \& Engineering Co., Inc.)

Reynolds Electrical \& Engineering Co., Inc. 1982. Nevada Test Site, Long Range Radioactive Waste Consolidation Plan, Fiscal Year 1983 through Fiscal Year 1990. Las Vegas, NV.

Shaw. 2002. Results of Geophysical Survey Selected FFACO Sites, Nevada Test Site, Nevada

Shott, G.J., V. Yucel, M.J. Sully, L.E. Barker, S.E. Rawlinson, and B.A. Moore. 1997. Performance Assessment/Composite Analysis for the Area 3 Radioactive Waste Management Site at the Nevada Test Site, Nye County, Nevada, Rev. 2.0. Las Vegas, NV.

U.S. Department of Energy. 1993. Radiation Protection of the Public and the Environment, DOE Order 5400.5, chg.2. Washington, DC: U.S. Government Printing Office.

U.S. Department of Energy, National Nuclear Security Administration Nevada Operations Office. 2002a. Industrial Sites Quality Assurance Project Plan, Nevada Test Site, Nevada, Rev. 3, DOE/NV--372. Las Vegas, NV.

U.S. Department of Energy, National Nuclear Security Administration Nevada Operations Office. 2002b. Underground Test Area Project Waste Management Plan, Rev. 2, DOE/NV--343. Las Vegas, NV. 
U.S. Department of Energy, Nevada Operations Office. 1992. Remedial Investigation and Feasibility Study for the Plutonium Contaminated Soils at Nevada Test Site, Nellis Air Force Range and Tonopah Test Range, April. Las Vegas, NV.

U.S. Department of Energy, Nevada Operations Office. 1996. Final Environmental Impact Statement for the Nevada Test Site and Off-Site Locations in the State of Nevada, DOE/EIS 0243, Las Vegas, NV

U.S. Department of Energy, Nevada Operations Office. 1998. Nevada Test Site Resource Management Plan, DOE/NV-518. Las Vegas, NV.

U.S. Department of Energy, Nevada Operations Office. 2000. United States Nuclear Tests July 1945 through September 1992, Rev. 15, DOE/NV--209. December. Las Vegas, NV.

U.S. Department of Energy, National Nuclear Security Administration Nevada Site Office. 2004. NV/YMP Radiological Control Manual, Rev. 4, DOE/NV/11718-079. Prepared by Bechtel Nevada. Las Vegas, NV.

U.S. Department of Energy, Nevada Operations Office. 2000a. Nevada Test Site Land Contamination Report Volume 1, DOE/NV-11718--481. Las Vegas, NV

U.S. Environmental Protection Agency. 2000a. Data Quality Objectives Process for Hazardous Waste Site Investigations. EPA QA/G-4HW. Washington, DC.

U.S. Environmental Protection Agency. 2000b. Guidance for the Data Quality Objective Process, EPA QA/G4. Washington, DC.

U.S. Environmental Protection Agency. 2002. Guidance for Quality Assurance Project Plans, EPA QA/G5. Washington, DC.

U.S. Environmental Protection Agency. 2004. Region 9 Preliminary Remediation Goals (PRGs). As accessed at http://www.epa.gov/region09/waste/sfund/prg/index.htm on 20 December 2005. Prepared by S.J. Smucker. San Francisco, CA.

U.S. Environmental Protection Agency. 2005. Integrated Risk Information System. As accessed at http://www.epa.gov/iriswebp/iris/index.html on 20 December 2005. 
CAU 139 Closure Report

Section: Appendix A

Revision: 0

Date: July 2009

THIS PAGE INTENTIONALLY LEFT BLANK 
CAU 139 Closure Report

Section: Appendix B

Revision: 0

Date: July 2009

\section{APPENDIX B}

\section{SAMPLE ANALYTICAL RESULTS}


CAU 139 Closure Report

Section: Appendix B

Revision: 0

Date: July 2009

THIS PAGE INTENTIONALLY LEFT BLANK 


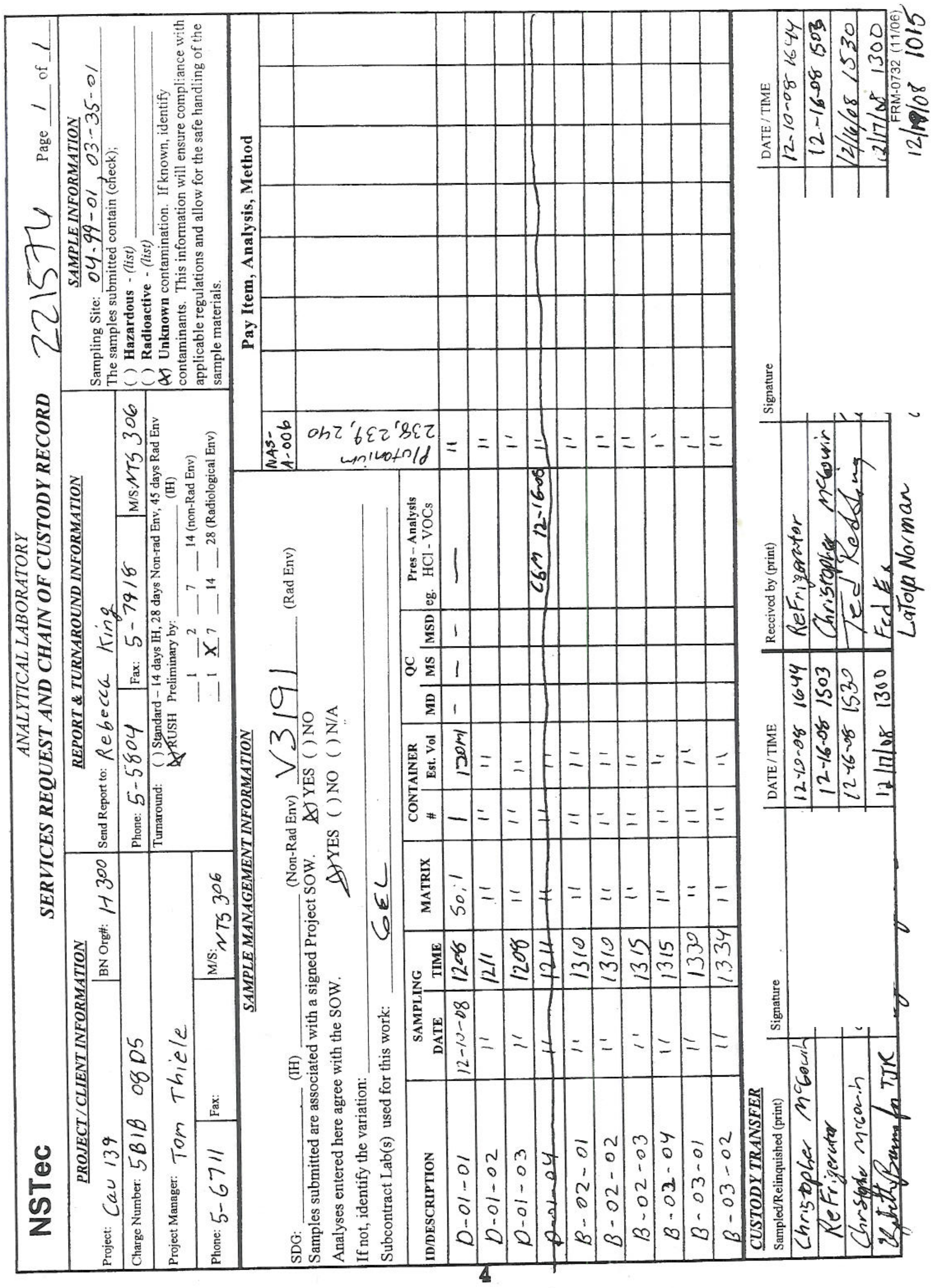




\section{Certificate of Analysis}

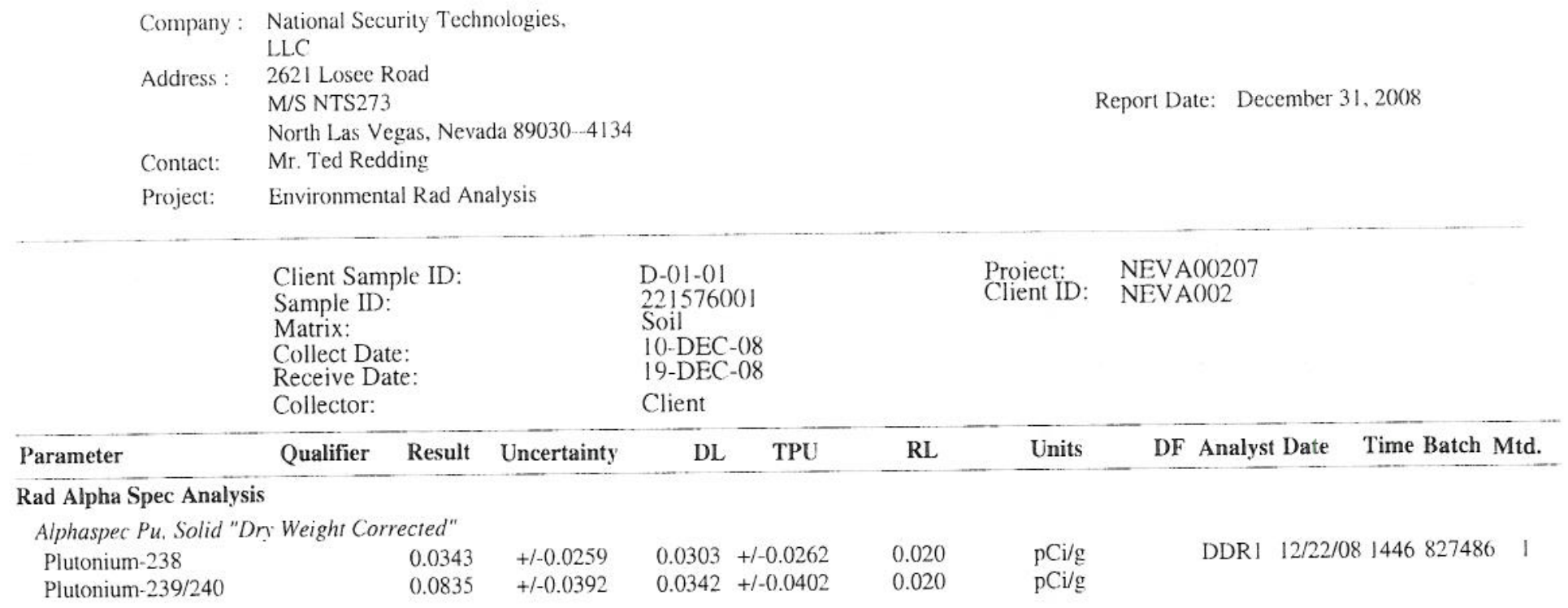

The following Analytical Methods were performed

Method Description

\begin{tabular}{llcc} 
Surrogate/Tracer recovery & Test & Recovery \% & Acceptable Limits \\
\hline Plutonium-242 Tracer & Alphaspec Pu, Solid "Dry Weight ( & 44 & $(15 \%-125 \%)$
\end{tabular}

Notes:

The Qualifiers in this report are defined as follows:

** Analyte is a surrogate compound

$<$ Result is less than value reported

$>$ Result is greater than value reported

A The TIC is a suspected aldol-condensation product

B For General Chemistry and Organic analysis the target analyte was detected in the associated blank.

$\mathrm{BD}$ Results are either below the MDC or tracer recovery is low

C Analyte has been confirmed by GC/MS analysis

D Results are reported from a diluted aliquot of the sample

F Estimated Value

$\mathrm{H}$ Analytical holding time was exceeded

$\mathrm{J}$ Value is estimated

M M if above MDC and less than LLD

M Matrix Related Failure

N/A RPD or \%Recovery limits do not apply.

ND Analyte concentration is not detected above the detection limit

NJ Consult Case Narrative, Data Summary package, or Project Manager concerning this qualifier

$\mathrm{R}$ Sample results are rejected

$\mathrm{U}$ Analyte was analyzed for, but not detected above the MDL, MDA, or LOD. 


\section{GEL LABORATORIES LLC}

2040 Savage Road Charleston SC 29407 - (843) 556-8171 - www.gel.com

\section{Certificate of Analysis}

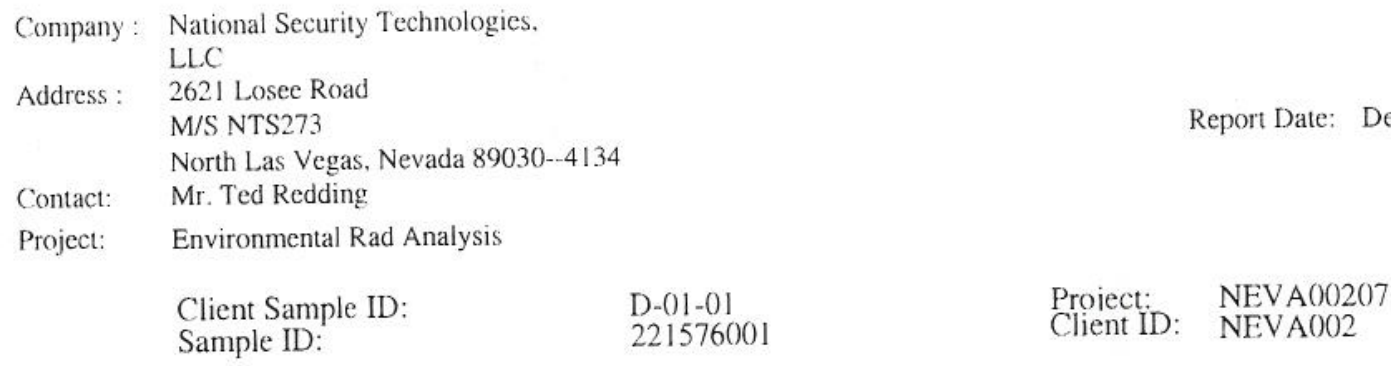

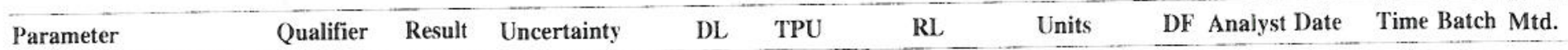

UI Gamma Spectroscopy--Uncertain identification

$\mathrm{X}$ Consult Case Narrative, Data Summary package. or Project Manager concerning this qualifier

Y QC Samples were not spiked with this compound

$\wedge$ RPD of sample and duplicate evaluated using +/-RL. Concentrations are $<5 \mathrm{X}$ the RL. Qualifier Not Applicable for Radiochemistry.

$\mathrm{h}$ Preparation or preservation holding time was exceeded

The above sample is reported on a dry weight basis. 


\section{Certificate of Analysis}

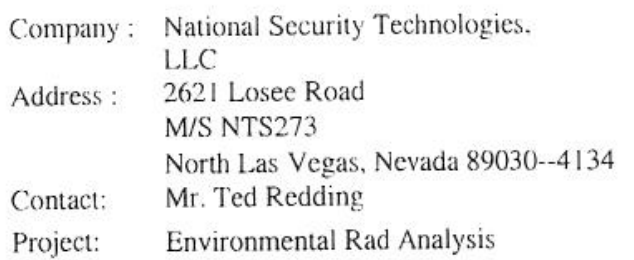

Project: Environmental Rad Analysis

$\begin{array}{ll}\text { Client Sample ID: } & \text { D-01-02 } \\ \text { Sample ID: } & 221576002 \\ \text { Matrix: } & \text { Soil } \\ \text { Collect Date: } & \text { 10-DEC-08 } \\ \text { Receive Date: } & \text { 19-DEC-08 } \\ \text { Collector: } & \text { Client }\end{array}$

\begin{tabular}{|c|c|c|c|c|c|c|c|c|c|c|c|}
\hline Parameter & Qualifier & Result & Uncertainty & $\mathrm{DL}$ & TPU & RL & Units & DF & Analyst Date & Time Batch $\mathrm{M}$ & Mtd. \\
\hline \multicolumn{12}{|c|}{ Rad Alpha Spec Analysis } \\
\hline \multicolumn{12}{|c|}{ Alphaspec Pu, Solid "Dry Weight Corrected" } \\
\hline $\begin{array}{l}\text { Plutonium-238 } \\
\text { Plutonium-239/240 }\end{array}$ & & $\begin{array}{r}0.0391 \\
0.162\end{array}$ & $\begin{array}{l}+/-0.0208 \\
+/-0.0407\end{array}$ & $\begin{array}{l}0.0184 \\
0.0184\end{array}$ & $\begin{array}{l}+/-0.0211 \\
+/-0.0436\end{array}$ & $\begin{array}{l}0.020 \\
0.020\end{array}$ & $\begin{array}{l}\mathrm{pCi} / \mathrm{g} \\
\mathrm{pCi} / \mathrm{g}\end{array}$ & & DDR $1 \quad 12 / 22 / 0$ & 81446827486 & 1 \\
\hline
\end{tabular}

The following Analytical Methods were performed

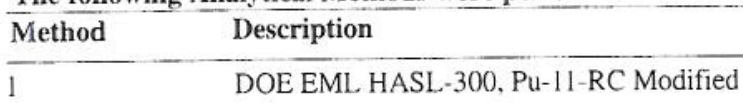

Surrogate/Tracer recovery

Test Recovery \% Acceptable Limits

Plutonium-242 Tracer Alphaspec Pu, Solid "Dry Weight c

74

$\begin{array}{ll}\text { Proiect: } & \text { NEVA00207 } \\ \text { Client ID: } & \text { NEVA002 }\end{array}$

Notes:

The Qualifiers in this report are defined as follows :

** Analyte is a surrogate compound

$<$ Result is less than value reported

$>$ Result is greater than value reported

A The TIC is a suspected aldol-condensation product

B For General Chemistry and Organic analysis the target analyte was detected in the associated blank.

$\mathrm{BD}$ Results are either below the MDC or tracer recovery is low

C Analyte has been confirmed by GC/MS analysis

D Results are reported from a diluted aliquot of the sample

F Estimated Value

$\mathrm{H}$ Analytical holding time was exceeded

$\mathrm{J}$ Value is estimated

M M if above MDC and less than LLD

M Matrix Related Failure

N/A RPD or \%Recovery limits do not apply.

ND Analyte concentration is not detected above the detection limit

NJ Consult Case Narrative, Data Summary package, or Project Manager concerning this qualifier

$\mathrm{R}$ Sample results are rejected

U Analyte was analyzed for, but not detected above the MDL, MDA, or LOD.

UI Gamma Spectroscopy--Uncertain identification 


\section{GEL LABORATORIES LLC}

2040 Savage Road Charleston SC 29407 - (843) 556-8171 - www.gel.com

\section{Certificate of Analysis}

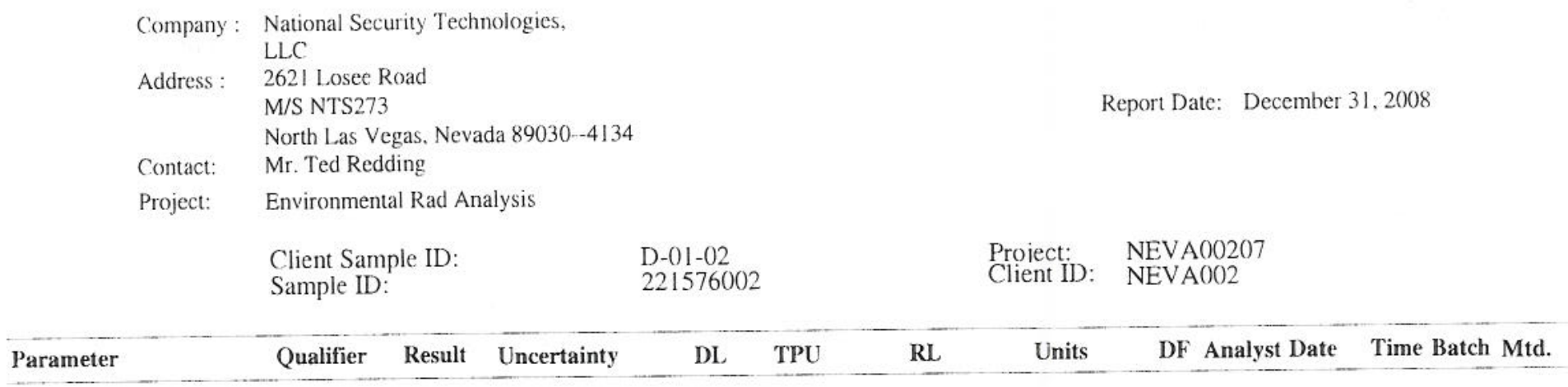

X Consult Case Narrative. Data Summary package. or Project Manager concerning this qualifier

Y QC Samples were not spiked with this compound

$\wedge$ RPD of sample and duplicate evaluated using $+/-R L$. Concentrations are $<5 X$ the RL. Qualifier Not Applicable for Radiochemistry.

$\mathrm{h}$ Preparation or preservation holding time was exceeded

The above sample is reported on a dry weight basis. 


\section{Certificate of Analysis}

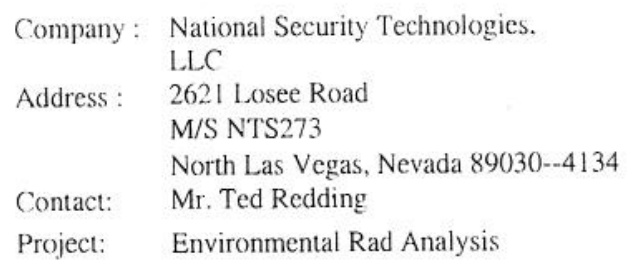

Project: Environmental Rad Analysis

Client Sample ID:

Sample ID:

Matrix:

Collect Date:

Receive Date:

Collector:

\author{
D- $01-03$ \\ 221576003 \\ Soil \\ 10-DEC-08 \\ 19-DEC-08 \\ Client
}

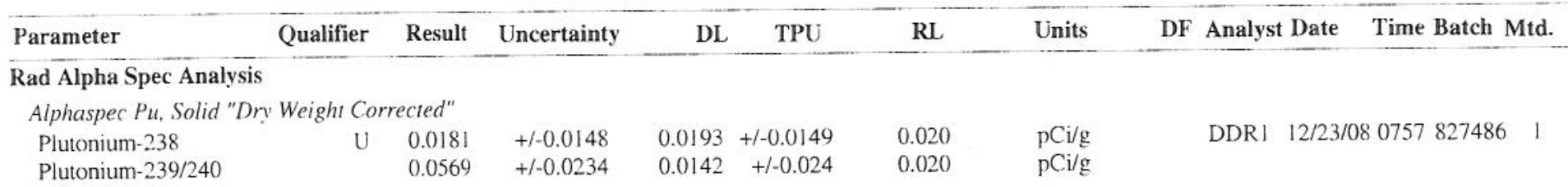

The following Analytical Methods were performed

Method - Description

\begin{tabular}{|c|c|c|c|}
\hline Surrogate/Tracer recovery & Test & Recovery \% & Acceptable Limits \\
\hline Plutonium-242 Tracer & Alphaspec Pu. Solid "Dry Weight ( & 79 & $(15 \%-125 \%)$ \\
\hline
\end{tabular}

Notes:

The Qualifiers in this report are defined as follows :

** Analyte is a surrogate compound

$<$ Result is less than value reported

$>$ Result is greater than value reported

A The TIC is a suspected aldol-condensation product

B For General Chemistry and Organic analysis the target analyte was detected in the associated blank.

$\mathrm{BD}$ Results are either below the MDC or tracer recovery is low

C Analyte has been confirmed by GC/MS analysis

D Results are reported from a diluted aliquot of the sample

F Estimated Value

$\mathrm{H}$ Analytical holding time was exceeded

$\mathrm{J}$ Value is estimated

M M if above MDC and less than LLD

M Matrix Related Failure

N/A RPD or \%Recovery limits do not apply.

ND Analyte concentration is not detected above the detection limit

NJ Consult Case Narrative, Data Summary package. or Project Manager concerning this qualifier

$\mathrm{R}$ Sample results are rejected

$\mathrm{U}$ Analyte was analyzed for, but not detected above the MDL, MDA, or LOD.

UI Gamma Spectroscopy--Uncertain identification 
GEL LABORATORIES LLC

2040 Savage Road Charleston SC 29407 - (843) 556-8171 - www.gel.com

\section{Certificate of Analysis}

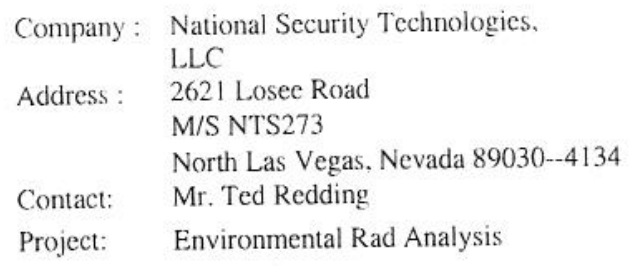

Parameter Qualifier Result Uncertainty DL TPU RL Units DF Analyst Date Time Batch Mtd.

X Consult Case Narrative. Data Summary package, or Project Manager concerning this qualifier

Y QC Samples were not spiked with this compound

$\wedge$ RPD of sample and duplicate evaluated using $+/-$ RL. Concentrations are $<5 X$ the RL. Qualifier Not Applicable for Radiochemistry.

h Preparation or preservation holding time was exceeded

The above sample is reported on a dry weight basis. 


\section{$\underline{\text { Certificate of Analysis }}$}

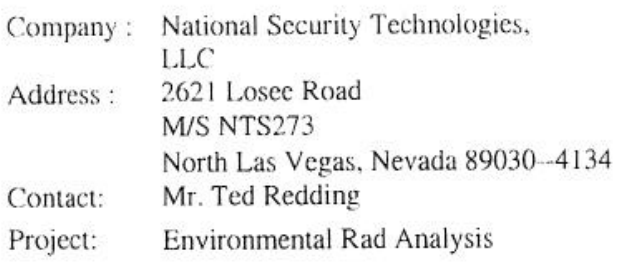

Project: Environmental Rad Analysis

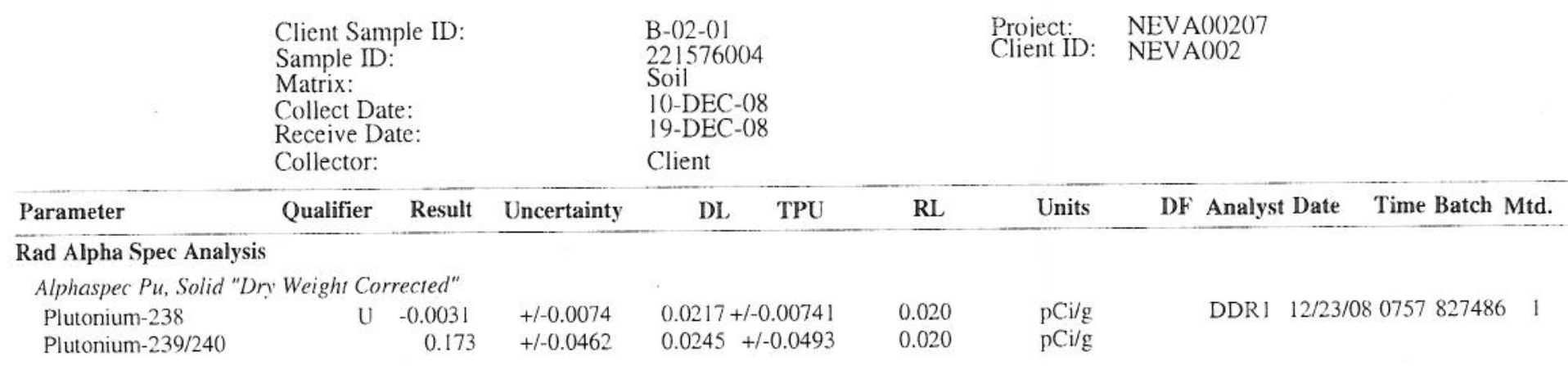

The following Analytical Methods were performed

Method $\frac{\text { Description }}{\text { DOE EML HASL-300, Pu-11-RC Modified }}$

\begin{tabular}{llcc} 
Surrogate/Tracer recovery & Test & Recovery \% & Acceptable Limits \\
\hline Plutonium-242 Tracer & Alphaspec Pu, Solid "Dry Weight ( & 60 & $(15 \%-125 \%)$
\end{tabular}

Notes:

The Qualifiers in this report are defined as follows :

** Analyte is a surrogate compound

$<$ Result is less than value reported

$>$ Result is greater than value reported

A The TIC is a suspected aldol-condensation product

B For General Chemistry and Organic analysis the target analyte was detected in the associated blank.

$\mathrm{BD}$ Results are either below the MDC or tracer recovery is low

C Analyte has been confirmed by GC/MS analysis

D Results are reported from a diluted aliquot of the sample

F Estimated Value

$\mathrm{H}$ Analytical holding time was exceeded

$\mathrm{J}$ Value is estimated

M M if above MDC and less than LLD

M Matrix Related Failure

N/A RPD or \%Recovery limits do not apply.

ND Analyte concentration is not detected above the detection limit

NJ Consult Case Narrative, Data Summary package, or Project Manager concerning this qualifier

$\mathrm{R}$ Sample results are rejected

U Analyte was analyzed for, but not detected above the MDL, MDA, or LOD.

UI Gamma Spectroscopy--Uncertain identification 


\section{GEL LABORATORIES LLC}

2040 Savage Road Charleston SC 29407 - (843) 556-8171 - www.gel.com

\section{Certificate of Analysis}

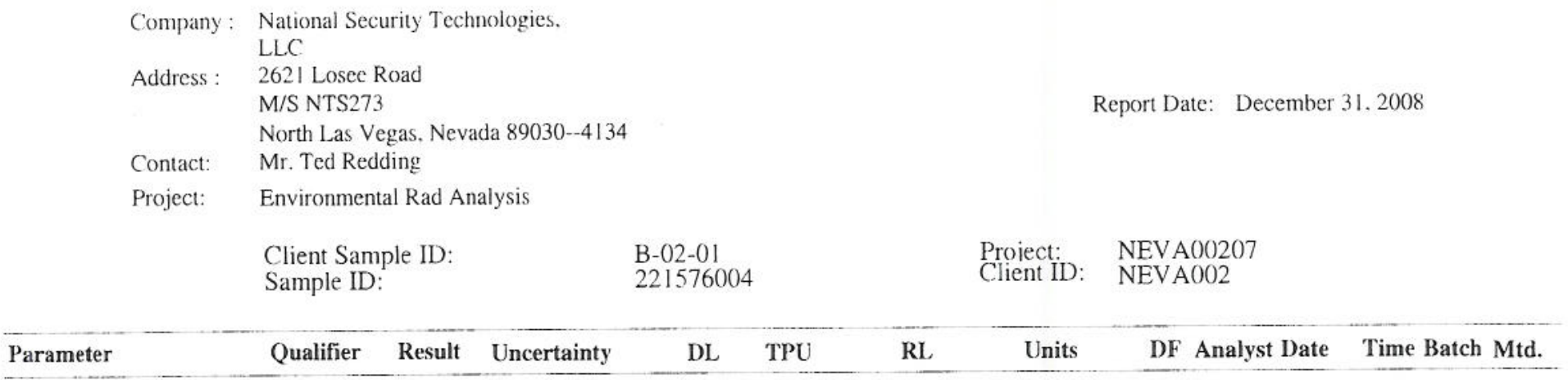

X Consult Case Narrative, Data Summary package, or Project Manager concerning this qualifier

Y QC Samples were not spiked with this compound

$\wedge$ RPD of sample and duplicate evaluated using $+/-$ RL. Concentrations are $<5 X$ the RL. Qualifier Not Applicable for Radiochemistry.

h Preparation or preservation holding time was exceeded

The above sample is reported on a dry weight basis. 
GEL LABORATORIES LLC

2040 Savage Road Charleston SC 29407 - (843) 556-8171 - www.gel.com

\section{Certificate of Analysis}

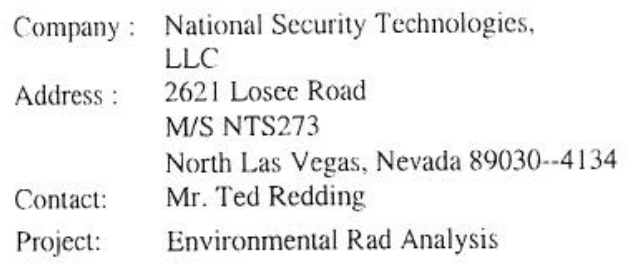

$\begin{array}{ll}\text { Client Sample ID: } & \text { B-02-02 } \\ \text { Sample ID: } & 221576005 \\ \text { Matrix: } & \text { Soil } \\ \text { Collect Date: } & \text { 10-DEC-08 } \\ \text { Receive Date: } & \text { 19-DEC-08 } \\ \text { Collector: } & \text { Client }\end{array}$

\begin{tabular}{|c|c|c|c|c|c|c|c|c|c|}
\hline Parameter & Qualifier & Result & Uncertainty & $\mathrm{DL}$ & TPU & $\mathrm{RL}$ & Units & DF Analyst Date & Time Batch N \\
\hline \multicolumn{10}{|c|}{ Rad Alpha Spec Analysis } \\
\hline \multicolumn{10}{|c|}{ Alphaspec Pu, Solid "Dry Weight Corrected" } \\
\hline $\begin{array}{l}\text { Plutonium-238 } \\
\text { Plutonium-239/240 }\end{array}$ & $\mathrm{U}$ & $\begin{array}{r}0.0154 \\
0.138\end{array}$ & $\begin{array}{l}+/-0.0154 \\
+/-0.0392\end{array}$ & $\begin{array}{l}0.0224 \\
0.0199\end{array}$ & $\begin{array}{l}+/-0.0155 \\
+/-0.0415\end{array}$ & $\begin{array}{l}0.020 \\
0.020\end{array}$ & $\begin{array}{l}\mathrm{pCi} / \mathrm{g} \\
\mathrm{pCi} / \mathrm{g}\end{array}$ & DDRI $12 / 23 / 08$ & 81327827486 \\
\hline
\end{tabular}

The following Analytical Methods were performed

$\begin{array}{ll}\text { Method } & \text { Description } \\ 1 & \text { DOE EML HASL-300, Pu-11-RC Modified }\end{array}$

\begin{tabular}{llcl} 
Surrogate/Tracer recovery & Test & Recovery \% & Acceptable Limits \\
\hline Plutonium-242 Tracer & Alphaspec Pu, Solid "Dry Weight ( & 68 & $(15 \%-125 \%)$
\end{tabular}

Notes:

The Qualifiers in this report are defined as follows :

** Analyte is a surrogate compound

$<$ Result is less than value reported

$>$ Result is greater than value reported

A The TIC is a suspected aldol-condensation product

B For General Chemistry and Organic analysis the target analyte was detected in the associated blank.

$\mathrm{BD}$ Results are either below the MDC or tracer recovery is low

C Analyte has been confirmed by GC/MS analysis

D Results are reported from a diluted aliquot of the sample

F Estimated Value

$\mathrm{H}$ Analytical holding time was exceeded

$\mathrm{J}$ Value is estimated

M M if above MDC and less than LLD

M Matrix Related Failure

N/A RPD or \%Recovery limits do not apply.

ND Analyte concentration is not detected above the detection limit

NJ Consult Case Narrative, Data Summary package, or Project Manager concerning this qualifier

$\mathrm{R}$ Sample results are rejected

U Analyte was analyzed for, but not detected above the MDL, MDA, or LOD.

UI Gamma Spectroscopy--Uncertain identification 


\section{GEL LABORATORIES LLC}

2040 Savage Road Charleston SC 29407 - (843) 556-8171 - www.gel.com

\section{Certificate of Analysis}

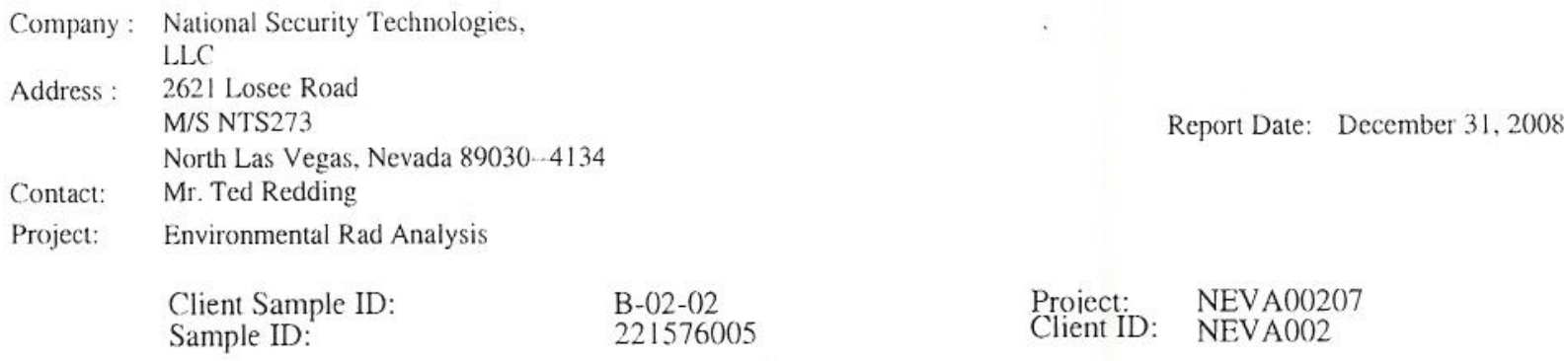

Parameter Qualifier Result Uncertainty DL TPU RL Units DF Analyst Date Time Batch Mtd.

X Consult Case Narrative, Data Summary package. or Project Manager concerning this qualifier

Y QC Samples were not spiked with this compound

$\wedge$ RPD of sample and duplicate evaluated using +/-RL. Concentrations are $<5 X$ the RL. Qualifier Not Applicable for Radiochemistry.

$\mathrm{h}$ Preparation or preservation holding time was exceeded

The above sample is reported on a dry weight basis. 


\section{GEL LABORATORIES LLC}

\section{Certificate of Analysis}

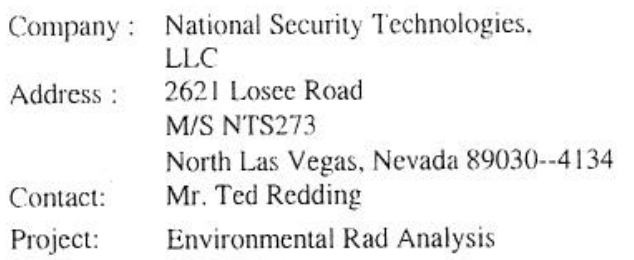

Project: Environmental Rad Analysis

$\begin{array}{ll}\text { Client Sample ID: } & \text { B-02-03 } \\ \text { Sample ID: } & 221576006 \\ \text { Matrix: } & \text { Soil } \\ \text { Collect Date: } & 10 \text {-DEC-08 } \\ \text { Receive Date: } & \text { 19-DEC-08 } \\ \text { Collector: } & \text { Client }\end{array}$

\begin{tabular}{|c|c|c|c|c|c|c|c|c|c|}
\hline Parameter & Qualifier & Result & Uncertainty & TPU & RL & Units & DF & Analyst Date & Time Batch Mtd. \\
\hline \multicolumn{10}{|c|}{ Rad Alpha Spec Analysis } \\
\hline \multicolumn{10}{|c|}{ Alphaspec Pu, Solid "Dry Weight Corrected" } \\
\hline $\begin{array}{l}\text { Plutonium-238 } \\
\text { Plutonium-239/240 }\end{array}$ & $\mathrm{U}$ & $\begin{array}{r}-0.00388 \\
0.275\end{array}$ & $\begin{array}{r}+/-0.00668 \\
+/-0.0526\end{array}$ & $\begin{array}{l}0.0204+/-0.00668 \\
0.0204+/-0.059\end{array}$ & $\begin{array}{l}0.020 \\
0.020\end{array}$ & $\begin{array}{l}\mathrm{pCi} / \mathrm{g} \\
\mathrm{pCi} / \mathrm{g}\end{array}$ & & DDR $1 \quad 12 / 23 / 0$ & $81327827486 \quad 1$ \\
\hline
\end{tabular}

The following Analytical Methods were performed

$\frac{\text { Method }}{1}$ DOE EML HASL-300, Pu-11-RC Modified

$\begin{array}{llcc}\text { Surrogate/Tracer recovery } & \text { Test } & \text { Recovery \% } & \text { Acceptable Limits } \\ \text { Plutonium-242 Tracer } & \text { Alphaspec Pu, Solid "Dry Weight } & 70 & (15 \%-125 \%)\end{array}$

Notes:

The Qualifiers in this report are defined as follows :

** Analyte is a surrogate compound

$<$ Result is less than value reported

$>$ Result is greater than value reported

A The TIC is a suspected aldol-condensation product

B For General Chemistry and Organic analysis the target analyte was detected in the associated blank.

$\mathrm{BD}$ Results are either below the MDC or tracer recovery is low

C Analyte has been confirmed by GC/MS analysis

D Results are reported from a diluted aliquot of the sample

F Estimated Value

$\mathrm{H}$ Analytical holding time was exceeded

$\mathrm{J} \quad$ Value is estimated

M M if above MDC and less than LLD

M Matrix Related Failure

N/A RPD or \% Recovery limits do not apply.

ND Analyte concentration is not detected above the detection limit

NJ Consult Case Narrative, Data Summary package, or Project Manager concerning this qualifier

$\mathrm{R}$ Sample results are rejected

U Analyte was analyzed for, but not detected above the MDL, MDA, or LOD.

UI Gamma Spectroscopy--Uncertain identification 


\section{GEL LABORATORIES LLC}

2040 Savage Road Charleston SC 29407 - (843) 556-8171 - www.gel.com

\section{Certificate of Analysis}

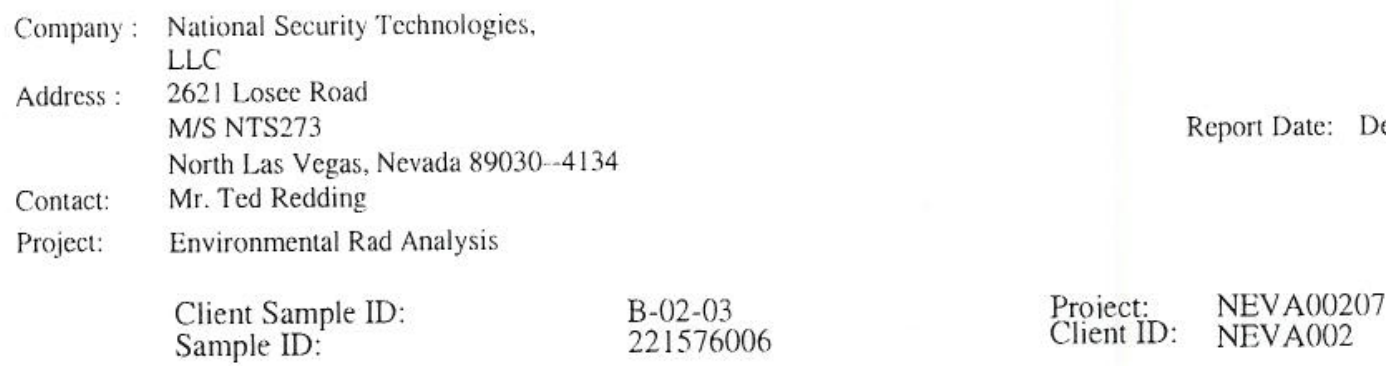

DL TPU

RL Units DF Analyst Date Time Batch Mtd.

X Consult Case Narrative, Data Summary package, or Project Manager concerning this qualifier

Y QC Samples were not spiked with this compound

$\wedge$ RPD of sample and duplicate evaluated using +/-RL. Concentrations are $<5 X$ the RL. Qualifier Not Applicable for Radiochemistry.

h Preparation or preservation holding time was exceeded

The above sample is reported on a dry weight basis. 


\section{Certificate of Analysis}

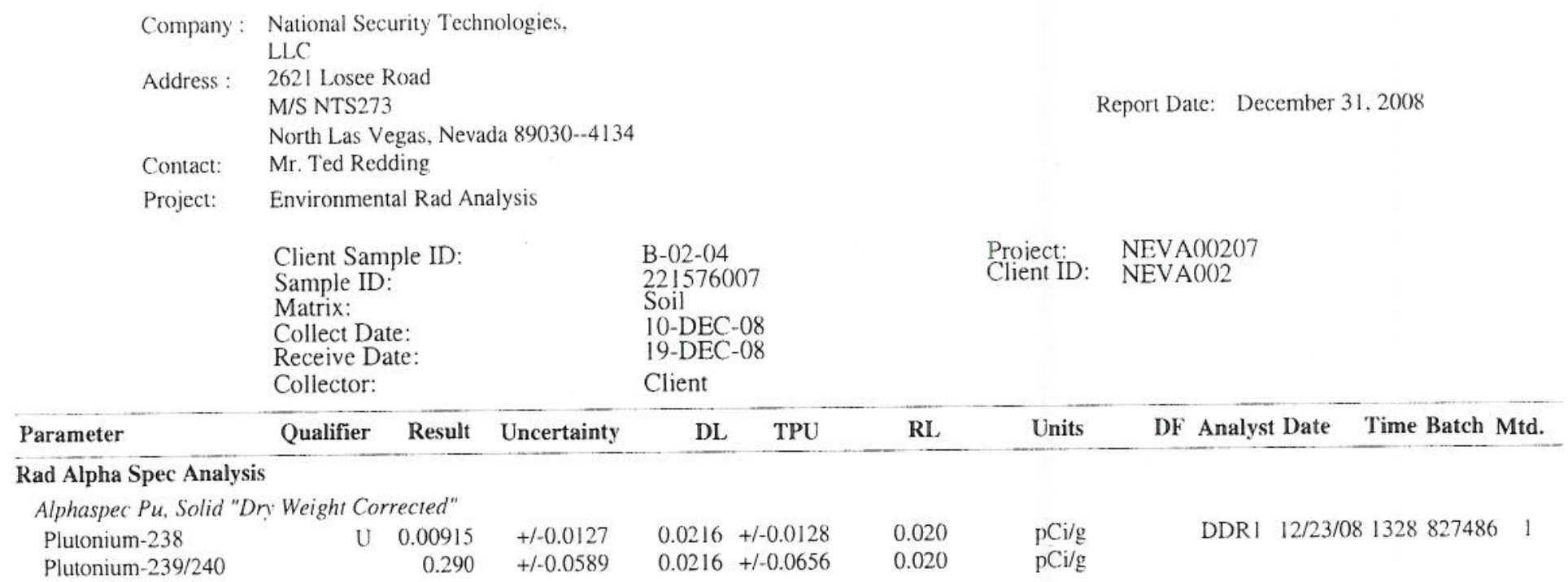

The following Analytical Methods were performed

Method $\quad$ Description

\begin{tabular}{|c|c|c|c|}
\hline Surrogate/Tracer recovery & Test & Recovery\% & Acceptable Limits \\
\hline Plutonium-242 Tracer & Alphaspec Pu, Solid "Dry Weight ( & 62 & $(15 \%-125 \%)$ \\
\hline
\end{tabular}

Notes:

The Qualifiers in this report are defined as follows :

** Analyte is a surrogate compound

$<$ Result is less than value reported

$>$ Result is greater than value reported

A The TIC is a suspected aldol-condensation product

B For General Chemistry and Organic analysis the target analyte was detected in the associated blank.

$\mathrm{BD}$ Results are either below the MDC or tracer recovery is low

C Analyte has been confirmed by GC/MS analysis

D Results are reported from a diluted aliquot of the sample

F Estimated Value

$\mathrm{H}$ Analytical holding time was exceeded

$\mathrm{J}$ Value is estimated

M M if above MDC and less than LLD

M Matrix Related Failure

N/A RPD or \%Recovery limits do not apply.

ND Analyte concentration is not detected above the detection limit

NJ Consult Case Narrative, Data Summary package, or Project Manager concerning this qualifier

$\mathrm{R}$ Sample results are rejected

$\mathrm{U}$ Analyte was analyzed for, but not detected above the MDL, MDA, or LOD.

UI Gamma Spectroscopy--Uncertain identification 


\section{GEL LABORATORIES LLC}

2040 Savage Road Charleston SC 29407 - (843) 556-8171 - www.gel.com

\section{Certificate of Analysis}

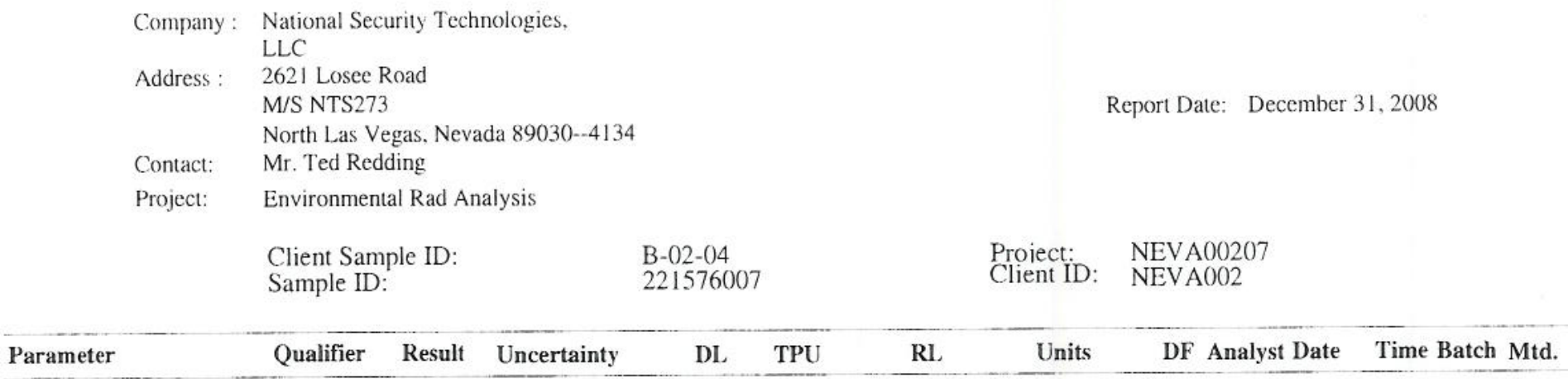

$X$ Consult Case Narrative, Data Summary package, or Project Manager concerning this qualifier

Y QC Samples were not spiked with this compound

$\wedge$ RPD of sample and duplicate evaluated using $+/-$ RL. Concentrations are $<5 X$ the RL. Qualifier Not Applicable for Radiochemistry.

$\mathrm{h}$ Preparation or preservation holding time was exceeded

The above sample is reported on a dry weight basis. 


\section{GEL LABORATORIES LLC}

2040 Savage Road Charleston SC 29407 - (843) 556-8171 - www.gel.com

\section{Certificate of Analysis}

Company: National Security Technologies,

LLC

Address: 2621 Losee Road

M/S NTS273

Report Date: December 31.2008

Contact: $\quad$ Mr. Ted Redding

Project: Environmental Rad Analysis

Client Sample ID: B-03-01 Proiect: NEVA00207

Sample ID: $\quad 221576008$ Client ID: NEVA002

Matrix:

Collect Date:

Receive Date:

Soil

10-DEC-08

19-DEC-08

Collector:

Client

\begin{tabular}{|c|c|c|c|c|c|c|c|c|c|c|c|}
\hline Parameter & Qualifier & Result & Uncertainty & $\mathrm{DL}$ & TPU & RL & Units & DF & Analyst Date & Time Batch $\mathrm{M}$ & Mtd. \\
\hline \multicolumn{12}{|c|}{ Rad Alpha Spec Analysis } \\
\hline \multicolumn{12}{|c|}{ Alphaspec Pu, Solid "Dry Weight Corrected" } \\
\hline $\begin{array}{l}\text { Plutonium-238 } \\
\text { Plutonium-239/240 }\end{array}$ & $\mathrm{U}$ & $\begin{array}{r}0.0156 \\
0.277\end{array}$ & $\begin{array}{l}+/-0.0155 \\
+/-0.0612\end{array}$ & $\begin{array}{l}0.0203 \\
0.0244\end{array}$ & $\begin{array}{l}+/-0.0156 \\
+/-0.0675\end{array}$ & $\begin{array}{l}0.020 \\
0.020\end{array}$ & $\begin{array}{l}\mathrm{pCi} / \mathrm{g} \\
\mathrm{pCi} / \mathrm{g}\end{array}$ & & DDR $1 \quad 12 / 23 / 0$ & 81328827486 & 1 \\
\hline
\end{tabular}

The following Analytical Methods were performed

Method Description

I DOE EML HASL-300, Pu-11-RC Modified

\begin{tabular}{llcc} 
Surrogate/Tracer recovery & Test & Recovery\% & Acceptable Limits \\
\hline Plutonium-242 Tracer & Alphaspec Pu, Solid "Dry Weight ( & 54 & $(15 \%-125 \%)$
\end{tabular}

Notes:

The Qualifiers in this report are defined as follows :

** Analyte is a surrogate compound

$<$ Result is less than value reported

$>$ Result is greater than value reported

A The TIC is a suspected aldol-condensation product

B For General Chemistry and Organic analysis the target analyte was detected in the associated blank.

BD Results are either below the MDC or tracer recovery is low

C Analyte has been confirmed by GC/MS analysis

D Results are reported from a diluted aliquot of the sample

F Estimated Value

$\mathrm{H}$ Analytical holding time was exceeded

$\mathrm{J}$ Value is estimated

M M if above MDC and less than LLD

M Matrix Related Failure

N/A RPD or \% Recovery limits do not apply.

ND Analyte concentration is not detected above the detection limit

NJ Consult Case Narrative, Data Summary package, or Project Manager concerning this qualifier

$\mathrm{R}$ Sample results are rejected

U Analyte was analyzed for, but not detected above the MDL, MDA, or LOD.

UI Gamma Spectroscopy--Uncertain identification 


\section{Certificate of Analysis}

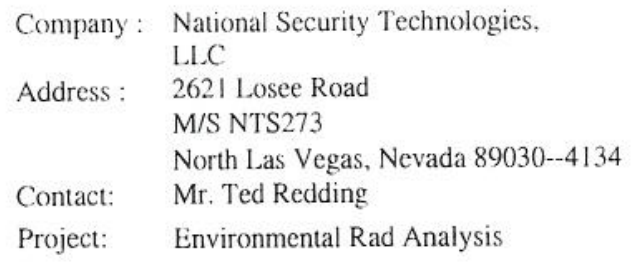

Parameter Qualifier Result Uncertainty DL TPU RL Units DF Analyst Date Time Batch Mtd.

X Consult Case Narrative. Data Summary package, or Project Manager concerning this qualifier

Y QC Samples were not spiked with this compound

$\wedge$ RPD of sample and duplicate evaluated using +/-RL. Concentrations are $<5 \mathrm{X}$ the RL. Qualifier Not Applicable for Radiochemistry.

$\mathrm{h}$ Preparation or preservation holding time was exceeded

The above sample is reported on a dry weight basis. 


\section{Certificate of Analysis}

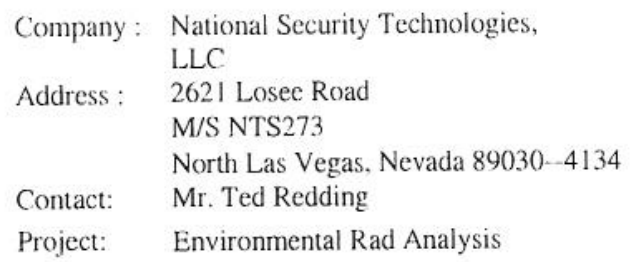

$\begin{array}{ll}\text { Client Sample ID: } & \text { B-(03-02 } \\ \text { Sample ID: } & 221576009 \\ \text { Matrix: } & \text { Soil } \\ \text { Collect Date: } & \text { 10-DEC-08 } \\ \text { Receive Date: } & \text { 19-DEC-08 } \\ \text { Collector: } & \text { Client }\end{array}$

\begin{tabular}{lrrrrrrrr}
\hline Parameter & Qualifier & Result & Uncertainty & DL & TPU & RL & Units & DF Analyst Date Time Batch Mtd. \\
Rad Alpha Spec Analysis & & & & & & & & \\
Alphaspec Pu, Solid "Dry Weight Corrected" & 0.0878 & $+/-0.0337$ & $0.0101+1-0.0349$ & 0.020 & pCi/g & DDRI $12 / 23 / 081328827486$ & 1 \\
Plutonium-238 & 0.812 & $+/-0.103$ & 0.0198 & $+/-0.132$ & 0.020 & pCi/g &
\end{tabular}

The following Analytical Methods were performed

Method $\frac{\text { Description }}{1}$ DOE EML HASL-300, Pu-11-RC Modified

\begin{tabular}{llcc} 
Surrogate/Tracer recovery & Test & Recovery \% & Acceptable Limits \\
\hline Plutonium-242 Tracer & Alphaspec Pu, Solid "Dry Weight ( & $55 \%-125 \%)$
\end{tabular}

Notes:

The Qualifiers in this report are defined as follows :

** Analyte is a surrogate compound

$<$ Result is less than value reported

$>$ Result is greater than value reported

A The TIC is a suspected aldol-condensation product

B For General Chemistry and Organic analysis the target analyte was detected in the associated blank.

$\mathrm{BD}$ Results are either below the MDC or tracer recovery is low

C Analyte has been confirmed by GC/MS analysis

D Results are reported from a diluted aliquot of the sample

F Estimated Value

$\mathrm{H}$ Analytical holding time was exceeded

$\mathrm{J}$ Value is estimated

M M if above MDC and less than LLD

M Matrix Related Failure

N/A RPD or \%Recovery limits do not apply.

ND Analyte concentration is not detected above the detection limit

NJ Consult Case Narrative, Data Summary package, or Project Manager concerning this qualifier

$\mathrm{R}$ Sample results are rejected

$\mathrm{U}$ Analyte was analyzed for, but not detected above the MDL, MDA, or LOD.

UI Gamma Spectroscopy--Uncertain identification 


\section{GEL LABORATORIES LLC}

2040 Savage Road Charleston SC 29407 - (843) 556-8171 - www.gel.com

\section{Certificate of Analysis}

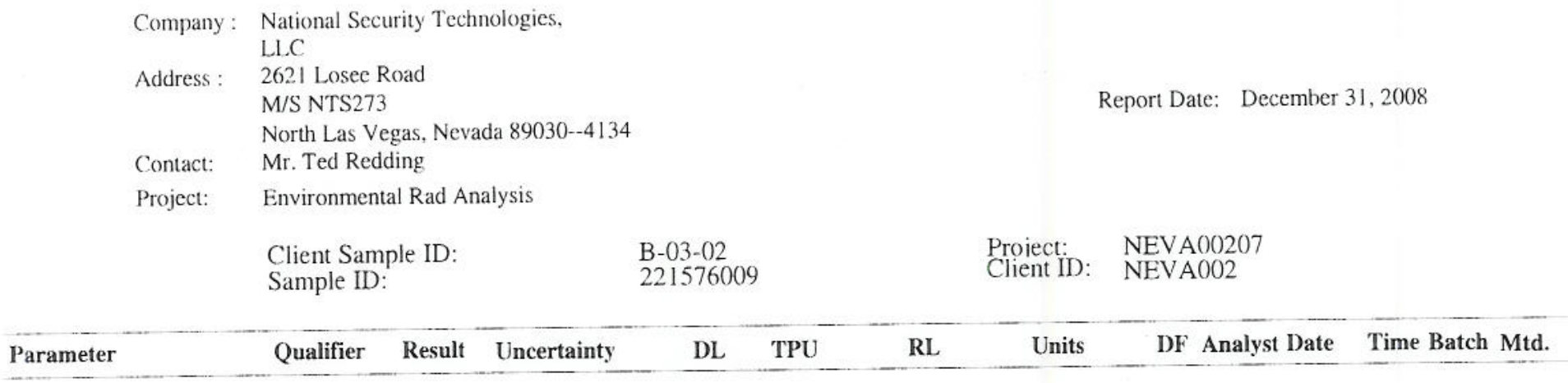

X Consult Case Narrative, Data Summary package. or Project Manager concerning this qualifier

Y QC Samples were not spiked with this compound

$\wedge$ RPD of sample and duplicate evaluated using +/-RL. Concentrations are $<5 X$ the RL. Qualifier Not Applicable for Radiochemistry.

$\mathrm{h}$ Preparation or preservation holding time was exceeded

The above sample is reported on a dry weight basis. 
CAU 139 Closure Report

Section: Appendix B

Revision: 0

Date: July 2009

THIS PAGE INTENTIONALLY LEFT BLANK 
CAU 139 Closure Report

Section: Appendix C

Revision: 0

Date: July 2009

APPENDIX C

WASTE DISPOSITION DOCUMENTATION 
CAU 139 Closure Report

Section: Appendix C

Revision: 0

Date: July 2009

THIS PAGE INTENTIONALLY LEFT BLANK 


\section{Certificate of Disposal}

This is to certify that the Waste Stream No. LRY5LLFY07002, container numbers 150000 (QG002990), 190000 (QG002994), 220000 (QG002997), 230000 (QG002998), and 270000 (QG003002), was shipped and received at the Nevada Test Site, Area 5 Radioactive Waste Management Complex for disposal as stated below.

Theresa Hale

Shipped by

Sign

Signature

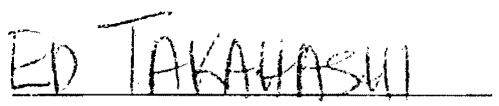

Received by

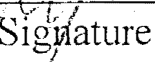

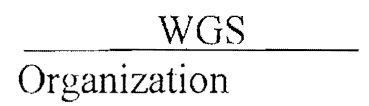

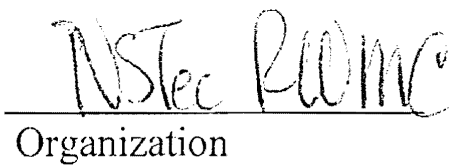

1.26 .09

Date

Senior Technical Support Title

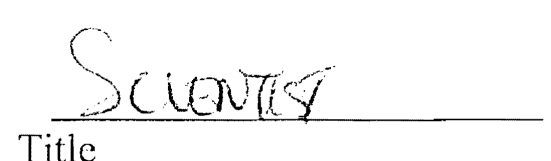

Title

Date 26 JAR-24Q9 


\begin{tabular}{llllll}
\hline SWO USE (Select One) & AREA & \23 & $\square 6$ & $\square 9$ & \ LANDFILL
\end{tabular}

For waste characterization, approval, and/or assistance, contact Solid Waste Operation (SWO) at 5-7898.

REQUIRED: WASTE GERERATOR INFORMATION

(This form is for rolloffs, dump trucks, and other onsite disposal of materials.)

Waste Generator: Christopher McGowin (45) Phone Number: $5-6211 \mathrm{~m} / \mathrm{s}$ 206 306 Location/Origin: CAU 139 CAS 06-19-0Z zene well 3

Waste Category: (check one) Commercial

$\bigotimes$ Industrial

Waste Type: $\square$ NTS Putrescrible

$\triangle$ FFACO-onsite WAC Exception (check one) Non-Putrescible

Asbestos Containing Material

Pollution Prevention Category: (check one) $\bigotimes$ Environmental management Pollution Prevention Category: (check one) $\bigotimes$ Clean-Up

$\square$ FFACO-offsite

$\square$ Historic DOE/NV

\section{Method of Characterization: (check one) Sampling \& Analysis \\ Prohibited waste at all three Radioactive waste; RCRA waste; Hazardous waste; Freeliquids, PCBs above TSC} NTS landifills:

Additional Prohibited Waste at the Area 9 U10C Landfill: levels, and Medical wastes (needles, sharps, bloody clothing).

Sewage Sludge, Animal carcasses, Wet garbage (food waste); and Friable asbestos

\section{REQUIRED: WASTE CONTENTS ALLOWABLE WASTES}

Check all allowable wastes that are contained within this load:

NOTE: Waste disposal at the Area 6 Hydrocarbon Landfill must have come into contact with petroleum hydrocarbons or coolants, such as: gasoline (no benzene, lead); jet fuel; diesel fuel; lubricants and hydraulics; kerosene; asphaltic petroleum hydrocarbon; and ethylene glycol.
Acceptable waste at any NTS landfill:
$\square$ Paper
$\triangle$ Rocks / unaltered geologic materials
$\square$ Empty containers
$\square$ Asphalt
$\bigotimes$ Metal
Wood
$\triangle$ Soil
$\square$ Rubber (excluding tires)
$\square$ Demolition debris
$\square$ Plastic
$\triangle$ Wire
$\square$ Cable
$\square$ Cloth
$\square$ Insulation (non-Asbestosform)
Cement \& concrete
Manufactured items: (swamp coolers, fumiture, rugs, carpet, electronic components, PPE, etc.)

\section{Additional waste accepted at the Area 23 Mercury Landfill: $\quad \square$ Office Waste $\square$ Food Waste}

Animal Carcasses

$\square$ Asbestos

Friable

$\square$ Non-Friable (contact SWO if regulated load)

Quantity:

Additional waste accepted at the Area 9 U10 c Landfill:
$\square$ Non-friable asbestos
$\square$ Drained automobiles and military vehicles
Solid fractions from sand/oil/water
$\square$ Light ballasts (contact SWO)
Drained fuel filters (gas \& diesel)
Deconned Underground and Above
Hydrocarbons (contact SWO)
Other
Ground Tanks

Additional waste accepted at the Area 6 Hydrocarbon Landfill:
$\square$ Septic sludge
[] Rags
Drained fuel filters (gas \& diesel)
Crushed non-teme plated oil filters
Plants
Soil
Sludge from sand/oil/water separators
PCBs below 50 parts per million REQUIRED: WASTE GENERATOR SIGNATURE

Initials: (if initialed, no radiological clearance is necessary.)

The above mentioned waste was generated outside of a Controlled Waste Mana knowledge, does not contain radiological materials.

To the best of my knowledge, the waste described above contains only those $m$ site. I have verified this through the waste characterization method identified al prohibited and allowable waste items. I have contacted Property Management : is approved for disposal in the landfill.

Print Name: Christopher McGowin

Radiological Survey Release for Waste Disposa RCT Initials

- This containeriload meets the criteria for no added man-made radloactive material

DS This containeriload meets the criteria for Radcon Manual Table 4.2 rolease limits. This container/load is exempt from survey due to process knowledge and origin. 12.4 .

SIGNATURE: ATE: 08 BN-0646 (10/05)

Signature:

Date: $12 \cdot 4-25$

here. Onsite use only.

Note: "Food waste, office trash and animal carcasses do not require a radiological ciearance. Freon-containing appliances must have signed removal certification statement with Load Verification."

SWO USE ONLY 


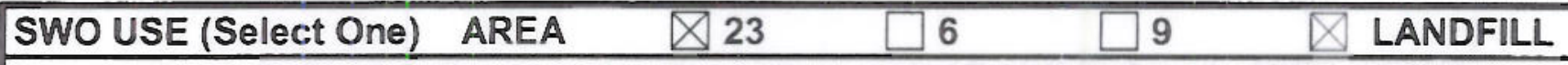

For waste characterization, approval, and/or assistance, contact Solid Waste Operation (SWO) at 5-7898.

\section{REQUIRED: WASTE GERERATOR INFORMATION}

(This form is for rolloffs, dump trucks, and other onsite disposal of materials.)

Waste Generator: Christopher McGowin Phone Number: 5-6211 Location / Origin: CAU 139 CAS 06-19-02

Waste Category: (check one)

Waste Type: $\triangle$ NTS

$\square$ Commercial
$\square$ Putrescrible
$\square$ Asbestos Containing Material
$\square$ Environmental management
$\bigotimes$ Clean-Up
$\square$ Sampling \& Analysis

$\triangle$ Industrial

(check one)

$\square$ Non-Putrescible

$\triangle$ FFACO-onsite

Pollution Prevention Category: (check one)

Pollution Prevention Category: (check one)

Method of Characterization: (check one)

Sampling \& Analysis

$\square$ FFACO-offsite

$\square$ Defense Projects

$\square$ Routine

Prohibited Waste at all three

NTS landfills:

Additional Prohibited Waste at the Area 9 U10C Landfill:
Radioactive waste; RCRA waste; Hazardous waste; Free liquids, PCBs above TSCA regulatory levels, and Medical wastes (needles, sharps, bloody clothing).

Sewage Sludge, Animal carcasses, Wet garbage (food waste); and Friable asbestos

\section{REQUIRED: WASTE CONTENTS ALLOWABLE WASTES}

Check all allowable wastes that are contained within this load:

NOTE: Waste disposal at the Area 6 Hydrocarbon Landfill must have come into contact with petroleum hydrocarbons or coolants, such as: gasoline (no benzene, lead); jet fuel; diesel fuel; lubricants and hydraulics; kerosene; asphaltic petroleum hydrocarbon; and ethylene glycol.
Acceptable waste at any NTS landfill:
$\square$ Pape
$\triangle$ Rocks / unaltered geologic materials
Empty containers
$\square$ Asphalt $\bigotimes$ Metal $\square$ Wood
$\triangle$ Soil
$\square$ Rubber (excluding tires)
Demolition debris
$\square$ Plastic
Wire
Cable
Cloth
$\square$ Insulation (non-Asbestosform)
Cement \& concrete
Manufactured items: (swamp coolers, furniture, rugs, carpet, electronic components, PPE, etc.)
Additional waste accepted at the Area 23 Mercury Landfill: $\square$ Office Waste
$\square$ Asbestos
Friable
Non-Friable (contact SWO if regulated load)
Food Waste
Animal Carcasses
Quantity:

Additional waste accepted at the Area 9 U10 c Landfill:
$\square$ Non-friable asbestos
$\square$ Drained automobiles and military vehicles

\section{$\square$ Light ballasts (contact SwO)}
Drained fuel filters (gas \& diesel)
Hydrocarbons (contact SWO)
Other

Solid fractions from sand/oil/water

Deconned Underground and Above Ground Tanks

\section{Additional waste accepted at the Area 6 Hydrocarbon Landfill: \\ $\square$ Septic sludge $\square$ Rags $\quad \square$ Drained fuel filters (gas \& diesel) \\ Plants \\ [] Soil \\ $\square$ Sludge from sand/oil/water separators \\ Crushed non-teme plated oil filters PCBs below 50 parts per million REQUIRED: WASTE GENERATOR SIGNATURE}

Initials: (if initialed, no radiological clearance is necessary.)

The above mentioned waste was generated outside of a Controlled Waste Managemer knowledge, does not contain radiological materials.

To the best of my knowledge, the waste described above contains only those material site. I have verified this through the waste characterization method identified above a prohibited and allowable waste items. I have contacted Property Management and ha is approved for disposal in the landfill.

Print Name: Christopher McGowin

Signature:
Radiological Survey Release for Waste Disposal RCT Initials

- This container/load meets the criteria for no added man-made radioactive material

$05 /$ This container/load meets the criteria for Radcon Manual Table 4.2 release limits. This containerlload is exempt from survey due to process knowledge and origin. 12.4 SIGNATURE: DATE: 08 FRM-0646 (08/06

Note: "Food waste, office trash and animal carcasses do not require a radiological clearance. Freon-containing appliances must have signed removal certification statement with Load Verification."

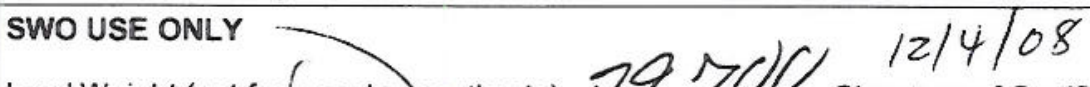

Load Weight (net from scale of estimate): 24 Signature of Certifier: 


\begin{tabular}{llllll}
\hline SWO USE (Select One) & AREA & $\mathbb{2} 23$ & $\square 6$ & $\square 9$ & $\square$ LANDFILL
\end{tabular}

For waste characterization, approval, and/or assistance, contact Solid Waste Operaticn (SWO) at 5-7898.

\section{REQUIRED: WASTE GERERATOR INFORMATION}

(This form is for rolloffs, dump trucks, and other onsite disposal of materials.)

Waste Generator: Christopher McGowin

Phone Number: 5-6211

Location / Origin: CAU 139 CAS 06-19-023

Waste Category: (check one)

Waste Type: $\triangle$ NTS

$\square$ Commercial

$\bigotimes$ Industrial

(check one)

$\square$ Non-Putrescible

$\square$ Putrescrible

$\triangle$ FFACO-onsite

Pollution Prevention Category: (check one) $\triangle$ Clean-Up

Method of Characterization: (check one)

Sampling \& Analysis

$\square$ FFACO-offsite

$\square$ WAC Exception

Prohibited Waste at all three

NTS landfills:

Radioactive waste; RCRA waste; Hazardous waste; Free liquids, PCBs above TSCA regulatory levels, and Medical wastes (needles, sharps, bloody clothing).

Additional Prohibited Waste at the Area 9 U10C Landfill:

Sewage Sludge, Animal carcasses, Wet garbage (food waste); and Friable asbestos

REQUIRED: WASTE CONTENTS ALLOWABLE WASTES

Check all allowable wastes that are contained within this load:

NOTE: Waste disposal at the Area 6 Hydrocarbon Landfill must have come into contact with petroleum hydrocarbons or coolants, such as: gasoline (no benzene, lead); jet fuel; diesel fuel; lubricants and hydraulics; kerosene; asphaltic petroleum hydrocarbon; and ethylene glycol.
Acceptable waste at any NTS landfill:
$\square$ Paper
Q Rocks / unaltered geologic materials
Empty containers
$\square$ Asphait
$\triangle$ Metal
$\bigotimes$ Wood
$\nabla$ Soil
$\square$ Rubber (excluding tires)
$\square$ Plastic $\triangle$ Wire
$\square$ Cable
$\square$ Cloth
$\square$ Insulation (non-Asbestosform)
Demolition debris

Manufactured items: (swamp coolers, furniture, rugs, carpet, electronic components, PPE, etc.)

Additional waste accepted at the Area 23 Mercury Landfill: $\square$ Office Waste

Asbestos

Friable

Non-Friable (contact SWO if regulated load)

Food Waste

Animal Carcasses

Additional waste accepted at the Area 9 U10c Landfill:

Drained automobiles and military vehicles

Solid fractions from sand/oil/water

$\square$ Light ballasts (contact SWO)

Drained fuel filters (gas \& diesel)

Deconned Underground and Above

Hydrocarbons (contact SWO)

Other

Ground Tanks

Additional waste accepted at the Area 6 Hydrocarbon Landfill:
$\square$ Septic sludge
$\square$ Rags
$\square$ Drained fuel filters (gas \& diesel)
Crushed non-teme plated oil filters
Plants
[] Soil
$\square$ Sludge from sand/oil/water separators
$\square$ PCBs below 50 parts per million
REQUIRED: WASTE GENERATOR SIGNATURE

Initials: (if initialed, no radiological clearance is necessary.)

The above mentioned waste was generated outside of a Controlled Waste Management Area (CWMA) and to the best of my knowledge, does not contain radiological materials.

To the best of my knowledge, the waste described above contains only those mat site. I have verified this through the waste characterization method identified abo prohibited and allowable waste items. I have contacted Property Management anc is approved for disposal in the landfill.

Print Name: Christopher McGowin

Signature: Date: $\underline{R-4}-5$

Note: "Food waste, office trash and animal carcasses do not require a radiological SIGNATURE:

Radiological Survey Release for Waste Disposal RCT initials

This container/load meets the criteria for no
added man-made radioactive material
This container/load meets the criteria for
Radcon Manual Table 4.2 release limits.
This container/load is exempt from survey
due to process knowledge and origin. $/ 2.4$
DIGNATURE:
must have signed removal certification statement with Load Verification." 


\begin{tabular}{|llllll}
\hline SWO USE (Select One) & AREA & $\square 23$ & $\square 6$ & $\square 9$ & $\square$ LANDFILL
\end{tabular}

For waste characterization, approval, and/or assistance, contact Solid Waste Operation (SWO) at 5-7898. REQUIRED: WASTE GERERATOR INFORMATION

(This form is for rolloffs, dump trucks, and other onsite disposal of materials.)

\begin{tabular}{|c|c|c|c|c|}
\hline laste Generator: & Christopher M & cGouin & Phone Number: & -6211 \\
\hline Location / Origin: & $\mathrm{cow} 139$ & $04-99-01$ & & \\
\hline Waste Catego & (check one) & $\square$ Commercial & 区 Industrial & \\
\hline Waste Type: & $\triangle$ NTS & $\square$ Putrescrible & 政ACO-onsite & $\square$ WAC EX \\
\hline (check one) & $\square$ Non-Putrescible & $\square$ Asbestos Containing Material & $\square$ FFACO-offsite & $\square$ Historic DOE/I \\
\hline Pollution Preven & tion Category: (check one) & ¿ Environmental management & $\square$ Defense Projects & $\square$ YMP \\
\hline Pollution Preven & ion Category: (check one) & $\triangle$ Clean-Up & $\square$ Routine & \\
\hline ethod of Char & cterization: (check one) & Х Sampling \& Analysis & $\square$ Process Knowlec & $\square \mathrm{Cor}$ \\
\hline
\end{tabular}

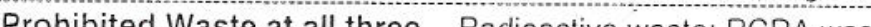
NTS landfills:

Additional Prohibited Waste at the Area 9 U10C Landfill: levels, and Medical wastes (needles, sharps, bloody clothing).

Sewage Sludge, Animal carcasses, Wet garbage (food waste); and Friable asbestos

\section{REQUIRED: WASTE CONTENTS ALLOWABLE WASTES}

Check all allowable wastes that are contained within this load:

NOTE: Waste disposal at the Area 6 Hydrocarbon Landfill must have come into contact with petroleum hydrocarbons or coolants, such as: gasoline (no benzene, lead); jet fuel; diesel fuel; lubricants and hydraulics; kerosene; asphaltic petroleum hydrocarbon; and ethylene glycol.
Acceptable waste at any NTS landfill:
$\square$ Asphalt
Metal

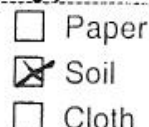
Rocks / unaltered geologic materials
$\square$ Rubber (excluding tires)
Plastic
Wire
Wood
$\square$ Cloth
$\square$ Insulation (non-Asbestosform)
Empty containers
$\square$ Demolition debris
Manufactured items: (swamp coolers, furniture, rugs, carpet, electronic components, PPE, etc.)
Cement \& concrete

Additional waste accepted at the Area 23 Mercury Landfill: $\quad \square$ Office Waste

$\square$ Asbestos

Friable

$\square$ Non-Friable (contact SWO if regulated load)

$\square$ Food Waste

Additional waste accepted at the Area 9 U10c Landfill:

Light ballasts (contact SWO)

Hydrocarbons (contact SWO)

Drained automobiles and military vehicles

Drained fuel filters (gas \& diesel)

Other

Quantity:

Additional waste accepted at the Area 6 Hydrocarbon Landfill:
$\square$ Septic sludge
$\square$ Rags
$\square$ Drained fuel filters (gas \& diesel)
Soil
$\square$ Sludge from sand/oil/water separators
REQUIRED: WASTE GENERATOR SIGNATURE
Plants

$\square$ Soil
Crushed non-teme plated oil filters PCBs below 50 parts per million

Solid fractions from sand/oil/water

Deconned Underground and Above Ground Tanks

Initials: (if initialed, no radiological clearance is necessary.)

The above mentioned waste was generated outside of a Controlled Waste Managemant $\triangle$ raa (CWMA) and to the best of my
knowledge, does not contain radiological materials.

To the best of my knowledge, the waste described above contains only those mate site. I have verified this through the waste characterization method identified abov prohibited and allowable waste items. I have contacted Property Management and is approved for disposal in the landfill.

Print Name: Chrostopher MCGoun

Signature: Date: $12+10-08$

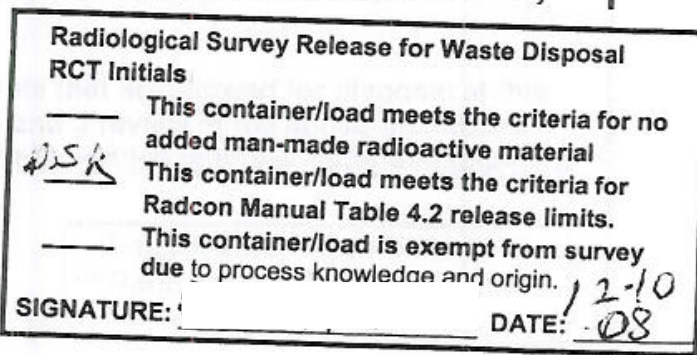

Note: "Food waste, office trash and animal carcasses do not require a radiological clearance. reuri-curnan....y unp......... must have signed romoval certification statement with Load Verification."

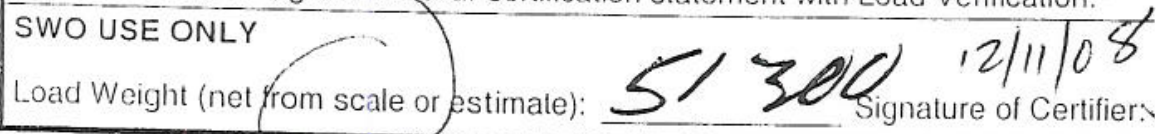

BN-0646(10/05) 


\begin{tabular}{|cccccc}
\hline SWO USE (Select One) AREA & $\square 23$ & $\square 6$ & AR & LANDFILL
\end{tabular}

For waste characterization, approval, and/or assistance, contact Solid Waste Operation (SWO) at 5-7898.

$$
\text { REQUIRED: WASTE GERERATOR INFORMATION }
$$

(This form is for rolloffs, dump trucks, and other onsite disposal of materials.)

Waste Generator:
Location / Origin:

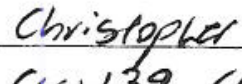
cow 139 ans os

colin

Waste Category: (check one)

Waste Type: 凶 NTS

(check one) $\square$ Non-Putrescible

Pollution Prevention Category: (check or

Pollution Prevention Category: (check one)

Method of Characterization: (check one)

Prohibited Waste at all three

NTS landfills:

Additional Prohibited Waste

at the Area 9 U10C Landfill:

\begin{abstract}
Radioactive waste; RCRA waste; Hazardous waste; Free liquids, PCBs above TSCA regulatory levels, and Medical wastes (needles, sharps, bloody clothing).
\end{abstract}

Sewage Sludge, Animal carcasses, Wet garbage (food waste); and Friable asbestos

\section{REQUIRED: WASTE CONTENTS ALLOWABLE WASTES}

Check all allowable wastes that are contained within this load:

NOTE: Waste disposal at the Area 6 Hydrocarbon Landfill must have come into contact with petroleum hydrocarbons or coolants, such as: gasoline (no benzene, lead); jet fuel; diesel fuel; lubricants and hydraulics; kerosene; asphaltic petroleum hydrocarbon; and ethylene glycol.
Acceptable waste at any NTS landfill:
$\square$ Asphalt
$\forall$ Metal
E Wood
$\square$ Paper
$\square$ Soil
$\square$ Cloth
Rocks / unaltered geologic materials
$\square$ Rubber (excluding tires)
$\square$ Insulation (non-Asbestosform)
$凶$ Plastic \# Wire $\square$ Cable

Manufactured items: (swamp coolers, furniture, rugs, carpet, electronic components, PPE, etc.)

Additional waste accepted at the Area 23 Mercury Landfill: $\quad \square$ Office Waste
$\square$ Asbestos
Friable
$\square$ Non-Friable (contact SWO if regulated load)

Food Waste

Quantity:

Additional waste accepted at the Area 9 U10c Landfill:

$\square$ Non-friable asbestos

$\square$ Light ballasts (contact SwO)

$\square$ Hydrocarbons (contact SWO)

Drained automobiles and military vehicles

Solid fractions from sand/oil/water

$\square$ Drained fuel filters (gas \& diesel)

Other

Additional waste accepted at the Area 6 Hydrocarbon Landfill:
Septic sludge
$\square$ Rags
Plants
$\square$ Soil
$\square$ Drained fuel filters (gas \& diesel)
$\square$ Sludge from sand/oil/water separators REQUIRED: WASTE GENERATOR SIGNATURE
Crushed non-teme plated oil filters PCBs below 50 parts per million

Deconned Underground and Above Ground Tanks (if initialed, no radiological clearance is necessary.)

The above mentioned waste was generated outside of a Controlled Waste Manageme knowledge, does not contain radiological materials.

To the best of my knowledge, the waste described above contains only those materi site. I have verified this through the waste characterization method identified above prohibited and allowable waste items. I have contacted Property Management and h is approved for disposal in the landfill.

Print Name: Christopher mooul's

Signalure: ${ }_{\text {Note: }}$ Food waste, ( Radiological Survey Release for Waste Disposal
RCT Initials
This container/load meets the criteria for no
added man-made radioactive material
This container/load meets the criteria for
Radcon Manual Table 4.2 release limits.
This container/load is exempt from survey
due to process knowledge and origin. 12.1$)$
SIGNATURE: must must have signed removal certification statement with Load Verification." 


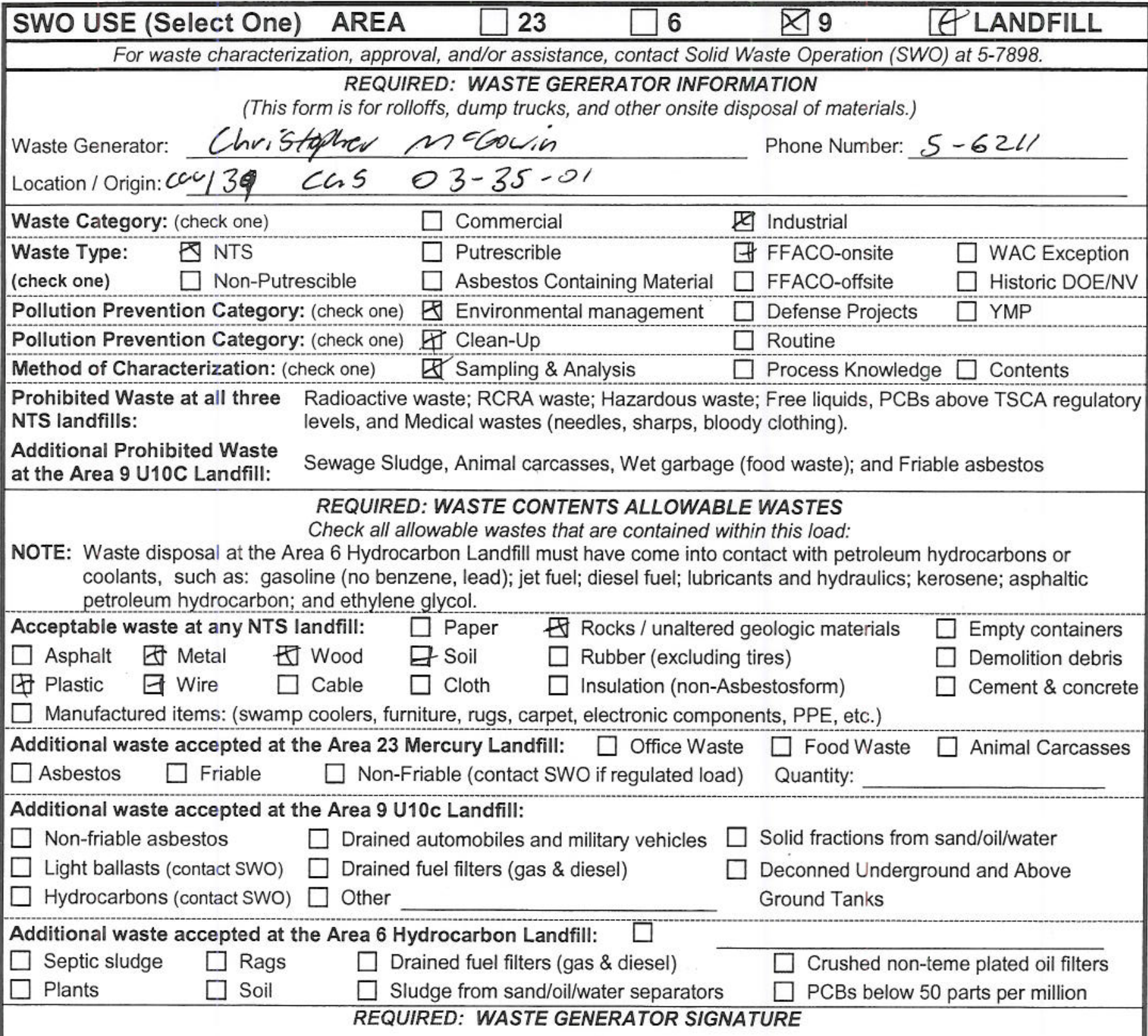

Initials: (if initialed, no radiological clearance is necessary.)

The above mentioned waste was generated outside of a Controlled Waste Management knowledge, does not contain radiological materials.

To the best of my knowledge, the waste described above contains only those materials site. I have verified this through the waste characterization method identified above an prohibited and allowable waste items. I have contacted Property Management and have is approved for disposal in the landfill. Print Name: Charstopher mCousin

Signature:

Note: "Food waste office Date: $12-11-08$
Radiological Survey Release for Waste Disposal RCT Initials

This container/load meets the criteria for no added man-made radioactive material

D. S. This container/load meets the criteria for Radcon Manual Table 4.2 release limits. This container/load is exempt from survey due to process knowledge and origin. $(2.1)$ SIGNATURE: DATE: -08 must have signed removal certification statement with Load Verification."

SWO USE ONLY

Load Weight (net from scale or estimate):

$$
12 / 11 / 08
$$
Signature of Certifier: ${ }^{c}$ 
and/or assistance, contact Solid Waste Operation (SWO) at 5-7898.

For waste characterization, approval, and/or assistance, contact Solid WaR INFORMATION

(This form is for rolloffs, dump trucks, and other onsite disposal of materials.)

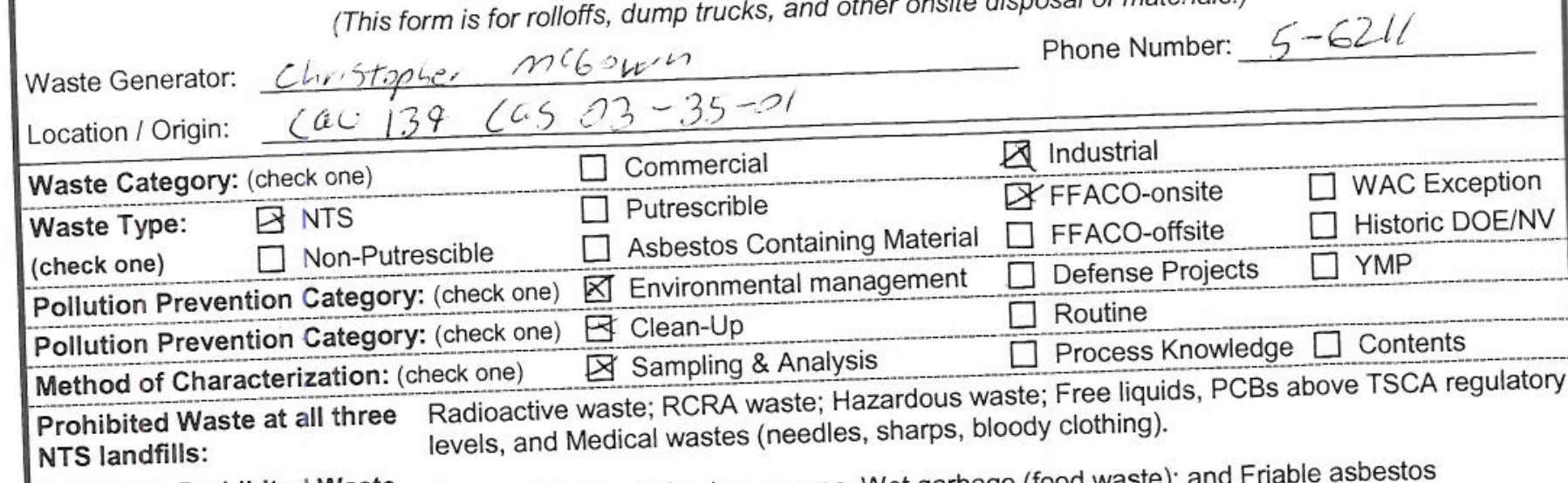

Additional Prohibited Waste at the Area 9 U10C Landfill:

Sewage Sludge, Animal carcasses, Wet garbage (food waste); and Friable asbestos

REQUIRED: WASTE CONTENTS ALLOWABLE WASTES

Check all allowable wastes that are contained within this load:
ind

NOTE: Waste disposal at the Area 6 Hydrocarbon Land); jet fuel; diesel fuel; lubricants and hydraulics; kerosene; asphaltic coolants, such as: gasoline (no benze glycol.
Acceptable waste at any NTS landfill:
$\square$ Paper
8 Soil
Asphalt
凶 Metal
$\Xi$ Wood
$\square$ Plastic $\square$ Cable $\square$ Cloth $\square$ Insulation (non-Asbestosform)
Manufactured items: (swamp coolers, furniture, rugs, carpet, electronic components, PPE, etc.)
Manufactured ite accepted at the Area 23 Mercury Landfill:
$\square$ Office Waste
Additional was
Area 9 U10c Landfill:
Additional waste accepted at the Area 9 U10c Landfill:
$\square$ Non-friable asbestos $\quad \square$ Drained automobiles and military vehicles
$\square$ Light ballasts (contact SWO) $\square$ Drained fuel filters (gas \& diesel)
$\square$ Hydrocarbons (contact SWO) $\square$ Other
Friable
SWO if regulated load)

$\triangle$ Rocks / unaltered geologic materials

Empty containers

$\square$ Rubber (excluding tires)

$\square$ Demolition debris

$\square$ Insulation (non-Asbestosform)

Cement \& concrete

$\square$ Food Waste

Animal Carcasses

Quantity:

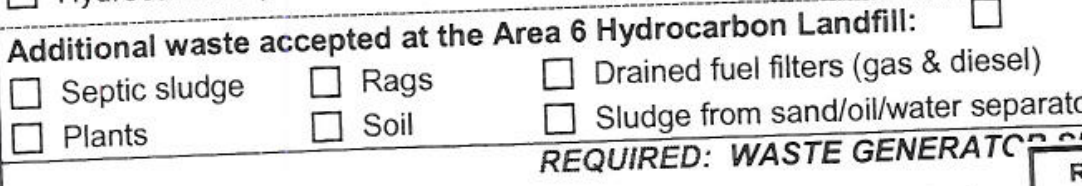

Initials: (if initialed, no radiological clearance is necessary.)

The above mentioned waste was generated outside of a Controlled Wast knowledge, does not contain radiological materials.

To the best of my knowledge, the waste described above contains only t site. I have verified this through the waste characterization method iden I allowable waste items. I have contacted Property Manag is approved for disposal in the landfill.

Print Name: Clwstyry Mrou. Date: $91-26-94$

Solid fractions from sand/oil/water

Deconned Underground and Above Ground Tanks

\section{Signature:}

7

\section{Date: $21-0,9 \%$}

Crushed non-teme plated oil filters PCBs below 50 parts per million Radiological Survey Release for Waste Disposal RCT Initials

This container/load meets the criteria This container/load meets the criteria for This container/load meets the crite limits. This container/load is exempt from survey due to process knowledge and origin.

SIGNATURE DATE: $1-6.09$ FRM-0646 (08/06) If applicable, place FRM-0646, "Radiological Release Sticker" here. Onsite use only.

\section{SWO USE ONLY}

Load Weight (net from scale or estimate):

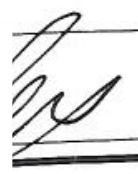


NSTec.

Form

FRM-0918

For waste characterization, approval, and/or assistance, contact Solid Waste Operation (SWO) at 5-7898.

REQUIRED: WASTE GERERATOR INFORMATION

(This form is for rolloffs, dump trucks, and other onsite disposal of materials.)

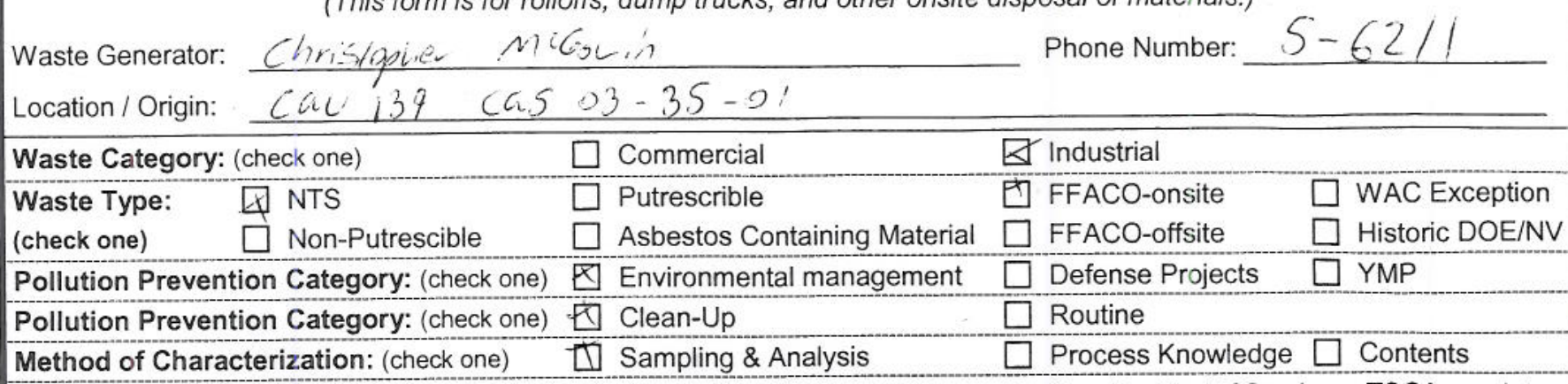

Prohibited Waste at all three Radioactive waste; RCRA waste; Hazardous waste; Free liquids, PCBs above TSCA regulatory NTS landfills:

levels, and Medical wastes (needles, sharps, bloody clothing). Additional Prohibited Waste Sewage Sludge, Animal carcasses, Wet garbage (food waste); and Friable asbestos
at the Area 9 U10C Landfill:

\section{REQUIRED: WASTE CONTENTS ALLOWABLE WASTES}

Check all allowable wastes that are contained within this load:

NOTE: Waste disposal at the Area 6 Hydrocarbon Landfill must have come into contact with petroleum hydrocarbons or coolants, such as: gasoline (no benzene, lead); jet fuel; diesel fuel; lubricants and hydraulics; kerosene; asphaltic petroleum hydrocarbon; and ethylene glycol.
Acceptable waste at any NTS landfill:
$\square$ Paper
甲 Rocks / unaltered geologic materials
Empty containers
$\square$ Asphalt
世 Wood
母 Soil
$\square$ Rubber (excluding tires)
$\square$ Demolition debris
$\square$ Plastic
母ire
ॠ Cable
$\square$ Cloth
$\square$ Insulation (non-Asbestosform)
Cement \& concrete
Manufactured items: (swamp coolers, furniture, rugs, carpet, electronic components, PPE, etc.)

Additional waste accepted at the Area 23 Mercury Landfill: $\quad \square$ Office Waste $\square$ Food Waste $\square$ Animal Carcasses
$\square$ Asbestos
Friable
Non-Friable (contact SWO if regulated load)
Quantity:

\section{Additional waste accepted at the Area 9 U10c Landfill:}
$\square$ Non-friable asbestos
$\square$
Light ballasts (contact SWO)
Hydrocarbons (contact SWO)
Drained automobiles and military vehicles
Drained fuel filters (gas \& diesel)
Other
Solid fractions from sand/oil/water
Deconned Underground and Above Ground Tanks

Additional waste accepted at the Area 6 Hydrocarbon Landfill:

$\begin{array}{lll}\square \text { Septic sludge } & \square \text { Rags } \\ \square \text { Plants } & \square \text { Soil } & \square \text { Srained fuel filters (gas \& diesel) } \\ \square \text { Sludge from sand/oil/water separators }\end{array}$

Initials: (if initialed, no radiological clearance is necessary.)

The above mentioned waste was generated outside of a Controlled Wastı knowledge, does not contain radiological materials.

To the best of my knowledge, the waste described above contains only the site. I have verified this through the waste characterization method identif prohibited and allowable waste items. I have contacted Property Managen is approved for disposal in the landfill.

Print Name: $C$ latigher Mcta! h

Signature:
Note: "Food waste, office trash and animal carcasses do not require a radiological clearance. Freon-containing appliances must have signed removal certification statement with Load Verification."
SWO USE ONLY $\square$ Crushed non-teme plated oil filters

$\square$ PCBs below 50 parts per million
Radiological Survey Release for Waste Disposal RCT Initials

This container/load meets the criteria for no

- -ded man-made radioactive material is container/load meets the criteria for Radcon Manual Table 4.2 release limits. This container/load is exempt from survey due to proesss knowledge and origin.

SIGNATURE: DATE: $1-6-09$ FRM-0646 (08/06)
If applicable, place FRM-0646, "Radiological Release Sticker" here. Onsite use only. 


$\begin{array}{llllll}\text { SWO USE (Select One) } & \text { AREA } & \square 23 & \square 6 & \searrow 9 & \square \text { LANDFILL }\end{array}$

For waste characterization, approval, and/or assistance, contact Solid Waste Operation (SWO) at 5-7898.

REQUIRED: WASTE GERERATOR INFORMATION

(This form is for rolloffs, dump trucks, and other onsite disposal of materials.)

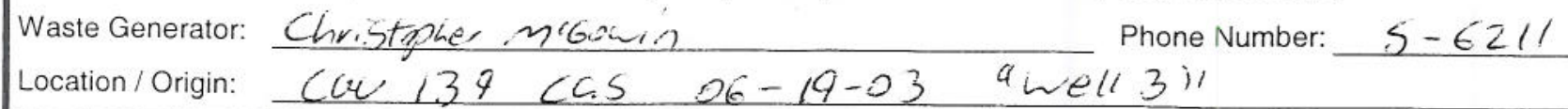

Waste Category: (check one) $\square$ Commercial $\square$ Industrial

Waste Type: $\quad$ NTS $\square$ Commercial

(check one) $\square$ Non-Putrescible $\square$ Asbestos Containing Material

Pollution Prevention Category: (check one) $\bigotimes$ Environmental management

Pollution Prevention Category: (check one) Clean-Up

Method of Characterization: (check one) $\square$ Sampling \& Analysis

R FFACO-onsite

$\square$ FFACO-offsite WAC Exception

$\square$ Defense Projects

Historic DOE/NV

$\square$ Routine

Prohibited Waste at all three NTS landfills:

Additional Prohibited Waste

at the Area 9 U10C Landfill:

$$
\text { Radioactive waste; RCRA waste; Hazardous waste; Free liquids, PCBs above TSCA regulatory }
$$
levels, and Medical wastes (needles, sharps, bloody clothing).

Sewage Sludge, Animal carcasses, Wet garbage (food waste); and Friable asbestos

\section{REQUIRED: WASTE CONTENTS ALLOWABLE WASTES}

Check all allowable wastes that are contained within this load:

NOTE: Waste disposal at the Area 6 Hydrocarbon Landfill must have come into contact with petroleum hydrocarbons or coolants, such as: gasoline (no benzene, lead); jet fuel; diesel fuel; lubricants and hydraulics; kerosene; asphaltic petroleum hydrocarbon; and ethylene glycol.
Acceptable waste at any NTS landfill:
Asphalt
\&. Metal
Wood
$\square$ Paper
Ex Soil
$\varangle$ Rocks / unaltered geologic materials
$\square$ Empty containers
Plastic
Cable
$\square$ Cloth
$\square$ Rubber (excluding tires)
$\square$ Insulation (non-Asbestosform)
$\square$ Demolition debris
Cement \& concrete

Manufactured items: (swamp coolers, furniture, rugs, carpet, electronic components, PPE, etc.)
Additional was
$\square$ Asbestos
$\square$ Friable
$\square$ Fialed
the Area 23 Mercury Landfill:
$\square$ Office Waste
Food Waste
Animal Carcasses Quantity:

\section{Additional waste accepted at the Area 9 U10c Landfill:}

$\square$ Non-friable asbestos

Light ballasts (contact SWO)

Hydrocarbons (contact SWO)

$\square$ Drained automobiles

$\square$ Drained fuel filters (gas \& diesel)

Other

Additional waste accepted at the Area 6 Hydrocarbon Landfill:
$\square$ Septic sludge
$\square$ Rags
$\square$ Drained fuel filters (gas \& diesel)
Sludge from sand/oil/water separators
Plants
$\square$ Soil
REQUIRED: WASTE GENERATOR SIGNATURE

Solid fractions from sand/oil/water

Deconned Underground and Above Ground Tanks

Initials: (if initialed, no radiological clearance is necessary.)

The above mentioned waste was generated outside of a Controlled Waste Management Area (CWMA) and to the best of my knowledge, does not contain radiological materials.

To the best of my knowledge, the waste described above contains only those materials that are allowed for disposal at this site. I have verified this through the waste characterization method identified above prohibited and allowable waste items. I have contacted Property Management and $\mathrm{r}$ is approved for disposal in the landfill.

Print Name: Chrstaher ncka,h

Signature: Date: $1-8-x 7$

Note: "Food waste, óffice trash and animal carcasses do not require a radiological $\mathrm{cl}$ must have signed removal certification statement with Load Verification."

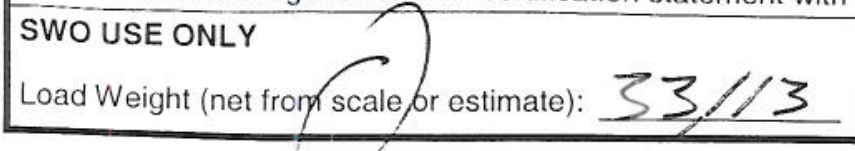

$1 / 8 / 09$

Signature of Certifier:
Radiological Survey Release for Waste Disposal RCT Initials

This container/load meets the criteria for no added man-made radioactive material This container/load meets the criteria for Radcon Manual Table 4.2 release limits. This container/load is exempt from survey due to prosess knowledge and origin,

SIGNATURE: DATE:

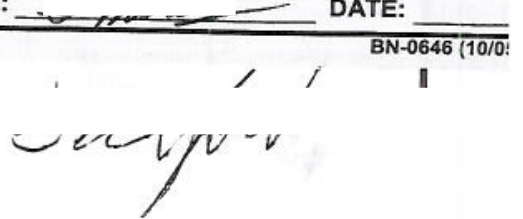


NSTec

Form

FRM-0918

NTS LANDFILL LOAD VERIFICATION

SWO USE (Select One) AREA

23

$\square 6$

凶9

I LANDFILL

For waste characterization, approval, and/or assistance, contact Solid Waste Operation (SWO) at 5-7898.

REQUIRED: WASTE GERERATOR INFORMATION

(This form is for rolloffs, dump trucks, and other onsite disposal of materials.)

Waste Generator: Chr.stance Mecue a

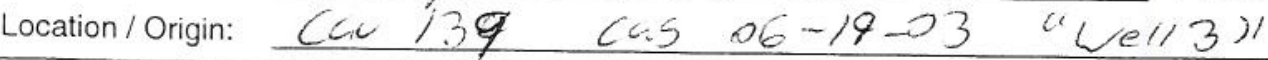

Waste Category: (check one)

Waste Type: $\triangle$ NTS

(check one) $\square$ Non-Putrescible $\square$ Asbestos Containing Material

Pollution Prevention Category: (check one) 凶 Environmental management

Pollution Prevention Category: (check one) $₫$ Clean-Up

Method of Characterization: (check one)

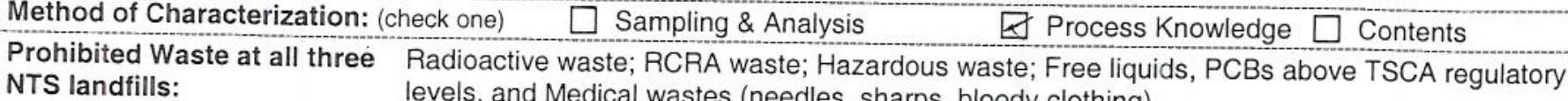

Phone Number: $5-6211$

Additional levels, and Medical wastes (needles, sharps, bloody clothing).

at the Area 9 U10C Landfill: Sewage Sludge, Animal carcasses, Wet garbage (food waste); and Friable asbestos

\section{REQUIRED: WASTE CONTENTS ALLOWABLE WASTES}

Check all allowable wastes that are contained within this load:

NOTE: Waste disposal at the Area 6 Hydrocarbon Landfill must have come into contact with petroleum hydrocarbons or coolants, such as: gasoline (no benzene, lead); jet fuel; diesel fuel; lubricants and hydraulics; kerosene; asphaltic petroleum hydrocarbon; and ethylene glycol.

Acceptable waste at any NTS landfill: $\square$ Paper $\square$ Rocks / unaltered geologic materials

$\square$ Asphalt $\quad$ Metal $\triangle$ Wood $\triangle$ Soil

$\square$ Plastic $\square$ Wire $\square$ Cable

$\square$ Cloth

$\square$ Rubber (excluding tires)

$\square$ Insulation (non-Asbestosform)

Empty containers

Demolition debris

$\square$ Manufactured items: (swamp coolers, furniture, rugs, carpet, electronic components, PPE, etc.)

Additional waste accepted at the Area 23 Mercury Landfill: $\quad \square$ Office Waste $\square$ Food Waste

Cement \& concrete

$\square$ Asbestos

$\square$ Friable

Non-Friable (contact SWO if regulated load)

Quantity:

Additional waste accepted at the Area 9 U10c Landfill:

$\begin{array}{ll}\square \text { Non-friable asbestos } & \square \text { Drained automobiles and military vehicles } \\ \square \text { Light ballasts (contact SWO) } \\ \square \text { Drained fuel filters (gas \& diesel) } \\ \square \text { Hydrocarbons (contact SWO) } \square \text { Other }\end{array}$

Solid fractions from sand/oil/water

Deconned Underground and Above Ground Tanks

Additional waste accepted at the Area 6 Hydrocarbon Landfill:
$\square$ Septic sludge
Plants
$\square$ Rags
$\square$ Drained fuel filters (gas \& diesel)
Crushed non-teme plated oil filters
$\square$ Sludge from sand/oil/water separators
PCBs below 50 parts per million

\section{REQUIRED: WASTE GENERATOR SIGNATURE}

Initials: (if initialed, no radiological clearance is necessary.)

The above mentioned waste was generated outside of a Controlled Waste Man knowledge, does not contain radiological materials.

To the best of my knowledge, the waste described above contains only those site. I have verified this through the waste characterization method identified prohibited and allowable waste items. I have contacted Property Management is approved for disposal in the landfill.

Print Name: Chotghe rogat h

Signature:

Note: "Food waste office trash and animal Date: $1-8.0$.

Radiological Survey Release for Waste Disposal RCT Initials

This container/load meets the criteria for no added man-made radioactive material This container/load meets the criteria for Radcon Manual Table 4.2 release limits. This container/load is exempt from survey due to progess, knowledge and origin.

SIGNATURE:

JATE: BN-0646(10/05)

Note: "Food waste, office trash and animal carcasses do not require a radiological clearance. Freon-containing appliances must have signed removal certification statement with Load Verification."

SWO USE ONLY

Load Weight (net from scale or estimate):

$$
1 / 8 / 09
$$




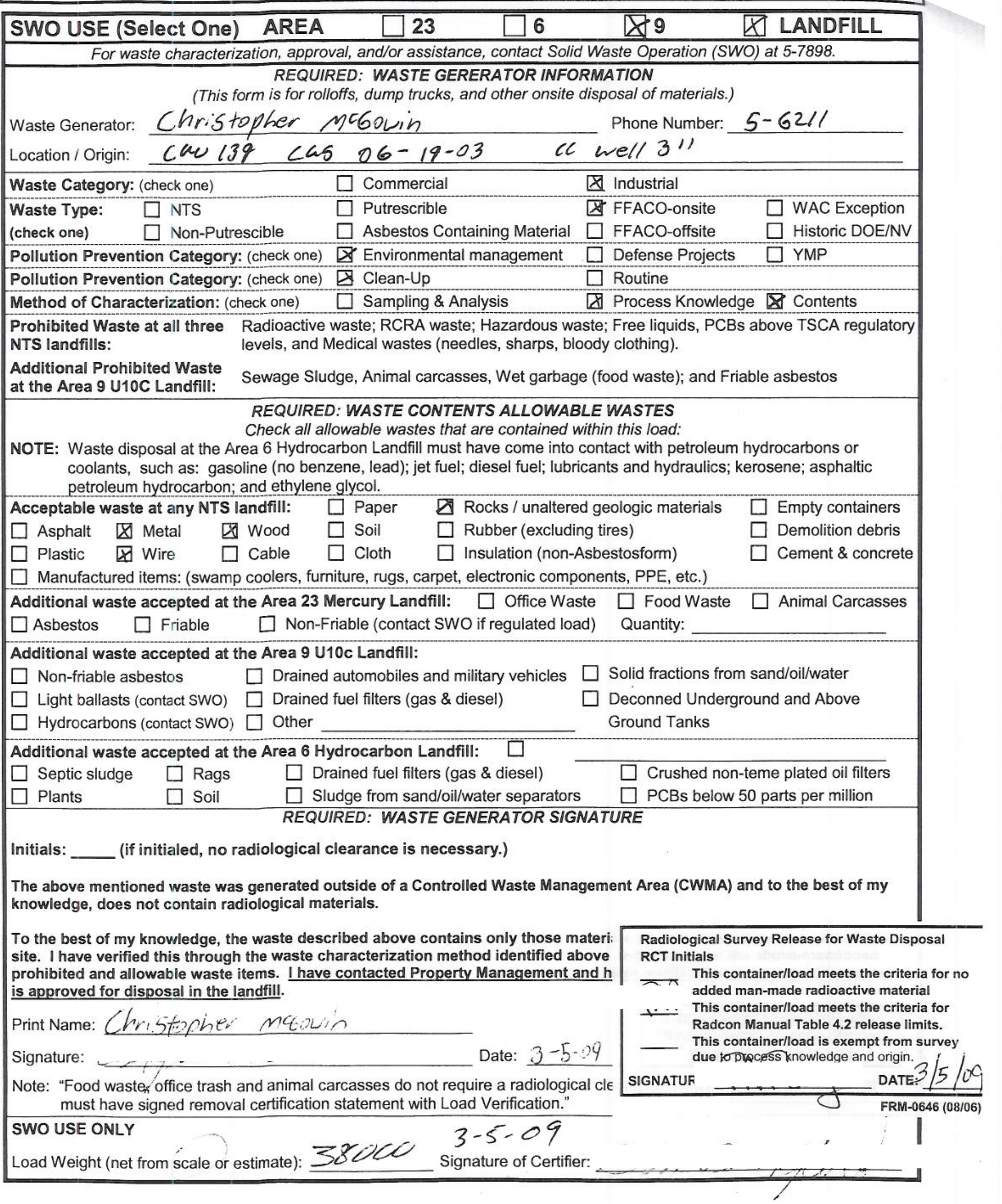


NSTEC

Form

FRM-0918

NTS LANDFILL LOAD VERIFICATION

\begin{tabular}{|c|}
\hline WO USE (Select One) \\
\hline
\end{tabular}

For waste characterization, approval, and/or assistance, contact Solid Waste Operation (SWO) at 5-7898.

REQUIRED: WASTE GERERATOR INFORMATION

(This form is for rolloffs, dump trucks, and other onsite disposal of materials.)

Waste Generator: Kevin Olsen

Phone Number: 5-2941

Location / Origin: Area 6 CAU 139 CAS 06-19-03

Waste Category: (check one)

Waste Type: $\triangle$ NTS

(check one)

$\square$ Non-Putrescible

$\square$ Commercial

$\bigotimes$ Industrial

$\square$ Putrescrible

FFACO-onsite

Asbestos Containing Material

$\square$ FFACO-offsite

WAC Exception

Pollution Prevention Category: (check one) \Environmental management -

Pollution Prevention Category: (check one) Q-eteam-Up cfs $3 / 4 / c \%$

$\triangle$ Defense-Projects

Method of Characterization: (check one) $<$ \& Sampling \& Analysis

7 Routine- 195

Prohibited Waste at all three

NTS landfills:

Additional Prohibited Waste

at the Area 9 U10C Landfill:

Radioactive waste; RCRA waste; Hazardous waste; Free liquids, PCBs above TSCA regulatory

levels, and Medical wastes (needles, sharps, bloody clothing).

Sewage Sludge, Animal carcasses, Wet garbage (food waste); and Friable asbestos

REQUIRED: WASTE CONTENTS ALLOWABLE WASTES

Check all allowable wastes that are contained within this load:

NOTE: Waste disposal at the Area 6 Hydrocarbon Landfill must have come into contact with petroleum hydrocarbons or coolants, such as: gasoline (no benzene, lead); jet fuel; diesel fuel; lubricants and hydraulics; kerosene; asphaltic petroleum hydrocarbon; and ethylene glycol.
Acceptable waste at any NTS landfill:
Asphalt
$\square$ Metal
$\square$ Wood
$\square$ Paper
$\triangle$ Soil
$\bigotimes$ Rocks / unaltered geologic materials
Empty containers
Plastic
Cable
$\square$ Cloth
$\square$ Rubber (excluding tires)
$\square$ Insulation (non-Asbestosform)
$\square$ Demolition debris
Cement \& concrete

Manufactured items: (swamp coolers, furniture, rugs, carpet, electronic components, PPE, etc.)
Additional waste accepted at the Area 23 Mercury Landfill: $\square$ Office Waste $\square$ Food
$\square$ Asbestos $\square$ Friable $\quad \square$ Non-Friable (contact SWO if regulated load) Quantity:
Additional waste accepted at the Area 23 Mercury Landfill: $\square$ Office Waste $\square$ Food
$\square$ Asbestos $\quad \square$ Friable $\quad \square$ Non-Friable (contact SWO if regulated load) Quantity:
Additional waste accepted at the Area 23 Mercury Landfill: $\square$ Office Waste $\square$ Food Waste
$\square$ Asbestos $\quad \square$ Friable $\quad \square$ Non-Friable (contact SWO if regulated load) Quantity:

Additional waste accepted at the Area 9 U10c Landfill:

$\square$ Non-friable asbestos

Light ballasts (contact SWO)

$\square$ Drained automobiles and military vehicles

Solid fractions from sand/oil/water

Hydrocarbons (contact SWO)

Drained fuel filters (gas \& diesel)

Deconned Underground and Above

Other

Ground Tanks

Additional waste accepted at the Area 6 Hydrocarbon Landfill:
$\square$ Septic sludge
$\square$ Rags
$\square$ Drained fuel filters (gas \& diesel)
Crushed non-teme plated oil filters
Plants
Soil
$\square$ Sludge from sand/oil/water separators
$\square$ PCBs below 50 parts per million REQUIRED: WASTE GENERATOR SIGNATURE

Initials: (if initialed, no radiological clearance is necessary.)

The above mentioned waste was generated outside of a Controlled Waste Management Area (CWMA) and to the best of my knowledge, does not contain radiological materials.

To the best of my knowledge, the waste described above contains only those mate site. I have verified this through the waste characterization method identified abov prohibited and allowable waste items. I have contacted Property Management and is approved for disposal in the landfill.

Print Name: Kevin Olsen

Signature: $\times 3-(2-\sigma 9)$

Note: "Food waste, office trash and animal carcasses do not require a radiological c must have signed removal certification statement with Load Verification."

SWO USE ONLY

Load Weight (net from/scale or estimate)

$3-12-09$

Signature of Certifie

Radiological Survey Release for Waste Disposal RCT Initials

This container/load meets the criteria for no added man-made radioactive material This container/load meets the criteria for Radcon Manual Table 4.2 release limits. This container/load is exempt from survey due to process knowledae and origin. SIGNATURE DATE:3-1/- O9

$\longrightarrow$ BN-0646(10/05)


CAU 139 Closure Report

Section: Appendix C

Revision: 0

Date: July 2009

\section{THIS PAGE INTENTIONALLY LEFT BLANK}


CAU 139 Closure Report

Section: Appendix D

Revision: 0

Date: July 2009

\section{APPENDIX D}

\section{USE RESTRICTION DOCUMENTATION}


CAU 139 Closure Report

Section: Appendix D

Revision: 0

Date: July 2009

THIS PAGE INTENTIONALLY LEFT BLANK 


\section{CAU Use Restriction Information}

CAU Number/Description: $\underline{\text { CAU 139, Waste Disposal Sites }}$

Applicable CAS Numbers/Descriptions: CAS 04-08-02, Waste Disposal Site

Contact (organization/project): $\underline{\text { NNSANSO Federal Industrial Sites Sub-Project Director }}$

Surveyed Area (UTM, Zone 11, NAD 27, meters):

\begin{tabular}{|c|c|c|}
\hline UR POINTS & NORTHING & EASTING \\
\hline NW Corner & $4,104,679.94017$ & $579,019.824049$ \\
\hline NE Corner & $4,104,622.68864$ & $579,173.644413$ \\
\hline SE Corner & $4,104,494.39004$ & $579,121.911107$ \\
\hline SW Corner & $4,104,560.60867$ & $578,969.470297$ \\
\hline
\end{tabular}

Survey Date: $\underline{05 / 21 / 2009}$ Survey Method (GPS, etc): $\underline{\text { N/A }}$

Site Monitoring Requirements: None

Required Frequency (quarterly, annually?): N/A

If Monitoring Has Started, Indicate last Completion Date: N/A

\section{Use Restrictions}

The future use of any land related to this Corrective Action Unit (CAU), as described by the above surveyed location, is restricted from any DOE or Air Force activity that may alter or modify the containment control as approved by the state and identified in the CAU Closure Report or other CAU documentation unless appropriate concurrence is obtained in advance.

Comments: This use restriction restricts individuals from working at the site for more than 42 days per year for 25 years. Radionuclides are present in the soil at concentrations above preliminary action levels (PALs) but do not exceed the final action levels calculated based on a remote work area scenario. The maximum concentration of cesium-137 is 23.3 picocuries per gram ( $\mathrm{pCi} / \mathrm{g}$ ), the maximum concentration of europium-152 is $119 \mathrm{pCi} / \mathrm{g}$, and the maximum concentration of europium-154 is $6.3 \mathrm{pCi} / \mathrm{g}$. Plutonium (Pu)-239 is also present at concentrations above the PAL; however, $\mathrm{Pu}-239$ is attributable to atmospheric tests and will be addressed under the Soils Project. The maximum concentration of Pu-239 is $130 \mathrm{pCi} / \mathrm{g}$. No postings or post-closure monitoring are required at this site.

Submitted By: /s/: Kevin Cabble Date: $\quad 7-2 z-09$ cc with copy of survey map (paper and digital (dgn) formats): CAU Files ( 2 copies) 


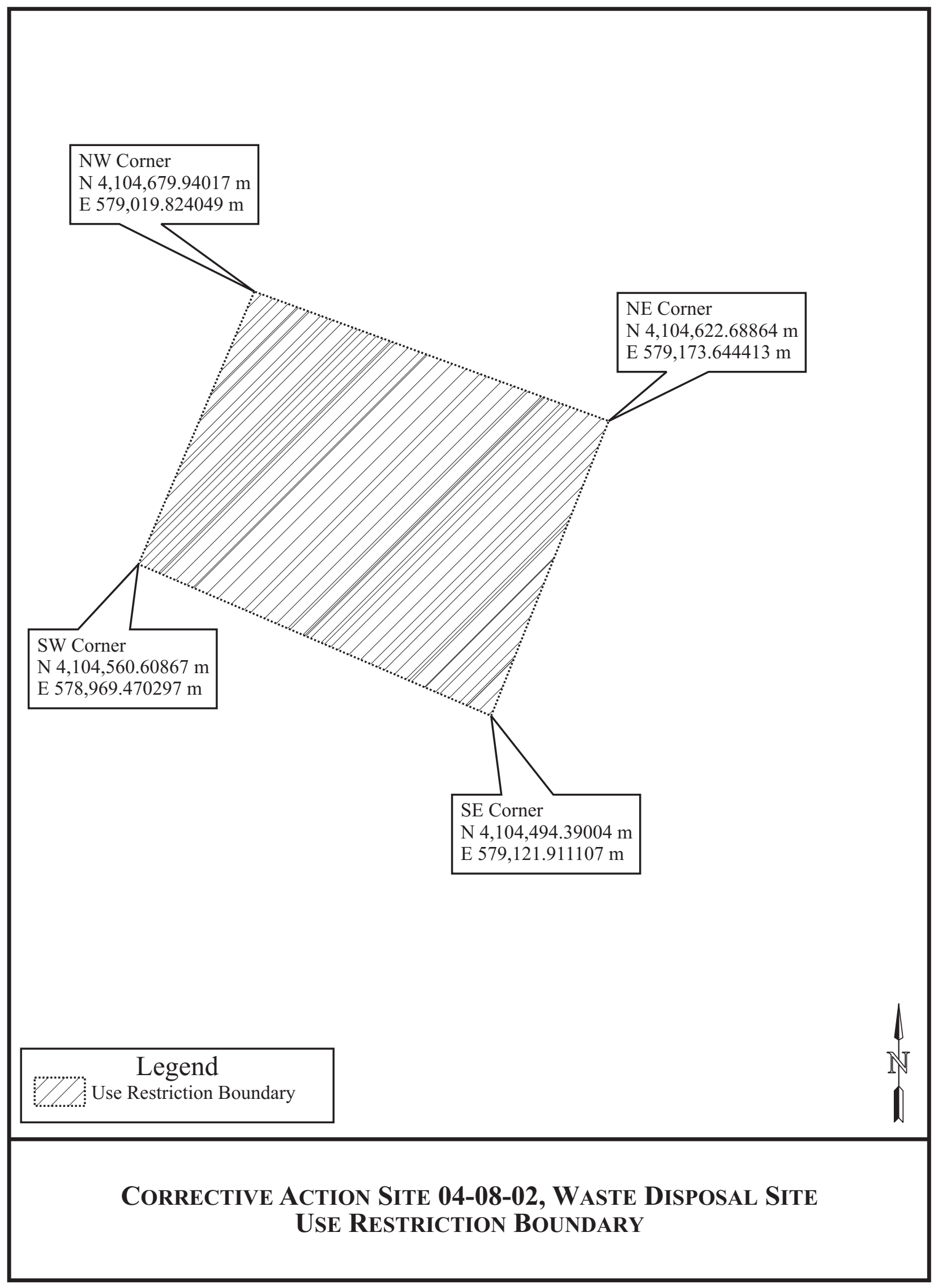




\section{CAU Use Restriction Information}

CAU Number/Description: CAU 139, Waste Disposal Sites

Applicable CAS Numbers/Descriptions: CAS 06-19-03, Waste Disposal Trenches

Contact (organization/project): $\underline{\text { NNSANSO Federal Industrial Sites Sub-Project Director }}$

Surveyed Area (UTM, Zone 11, NAD 27, meters):

\begin{tabular}{|c|c|c|}
\hline UR POINTS & NORTHING & EASTING \\
\hline Point 1 & $4,094,800.703$ & $583,843.264$ \\
\hline Point 2 & $4,094,807.845$ & $583,915.346$ \\
\hline Point 3 & $4,094,795.900$ & $583,942.445$ \\
\hline Point 4 & $4,094,746.322$ & $583,946.937$ \\
\hline Point 5 & $4,094,735.201$ & $583,848.982$ \\
\hline
\end{tabular}

Survey Date: $\underline{04 / 15 / 2009} \quad$ Survey Method (GPS, etc): $\underline{\text { GPS }}$

Site Monitoring Requirements: Visual Inspections

Required Frequency (quarterly, annually?): Annual

If Monitoring Has Started, Indicate last Completion Date: $\underline{\mathrm{N} / \mathrm{A}}$

\section{Use Restrictions}

The future use of any land related to this Corrective Action Unit (CAU), as described by the above surveyed location, is restricted from any DOE or Air Force activity that may alter or modify the containment control as approved by the state and identified in the CAU Closure Report or other CAU documentation unless appropriate concurrence is obtained in advance.

Comments: The use restriction (UR) is for radioactive and/or hazardous contaminants assumed to be present in the trenches. The future use of the UR area is restricted from any activity that may alter or modify the containment controls, unless appropriate concurrence is obtained in advance. Annual site inspections are required to ensure that the signs are intact and legible and that the UR is maintained. Maintenance or repair needs that are identified will be completed prior to the following inspection. Inspection results will be documented in the annual combined Nevada Test Site post-closure letter report.

Submitted By: /s/: Kevin Cabble cc with copy of survey map (paper and digital (dgn) formats):

CAU Files ( 2 copies) 


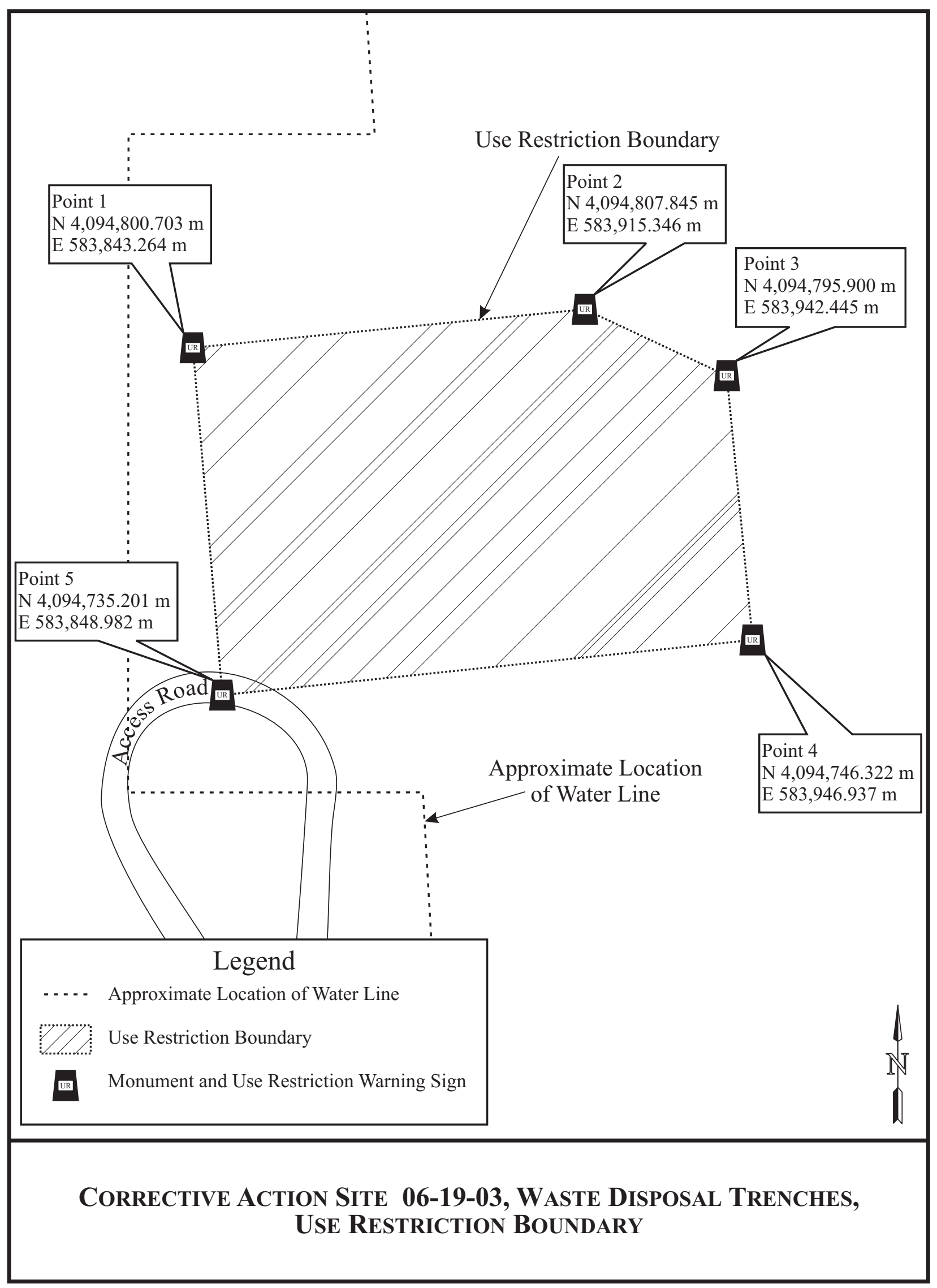




\section{CAU Use Restriction Information}

CAU Number/Description: $\underline{\text { CAU 139, Waste Disposal Sites }}$

Applicable CAS Numbers/Descriptions: CAS 09-23-01, Area 9 Gravel Gertie

Contact (organization/project): $\underline{\text { NNSA/NSO Federal Industrial Sites Sub-Project Director }}$

Surveyed Area (UTM, Zone 11, NAD 27, meters):

\begin{tabular}{|c|c|c|}
\hline UR POINTS & NORTHING & EASTING \\
\hline Point 1 & $4,109,072.25$ & $584,590.598$ \\
\hline Point 2 & $4,108,994.43$ & $584,587.114$ \\
\hline Point 3 & $4,108,983.16$ & $584,595.249$ \\
\hline Point 4 & $4,108,971.87$ & $584,611.664$ \\
\hline Point 5 & $4,108,964.32$ & $584,613.232$ \\
\hline Point 6 & $4,108,961.14$ & $584,619.608$ \\
\hline Point 7 & $4,108,989.99$ & $584,677.704$ \\
\hline Point 8 & $4,109,018.12$ & $584,705.531$ \\
\hline Point 9 & $4,109,024.39$ & $584,705.264$ \\
\hline Point 10 & $4,109,054.59$ & $584,667.284$ \\
\hline Point 11 & $4,109,096.93$ & $584,611.619$ \\
\hline
\end{tabular}

Survey Date: $\underline{09 / 27 / 2006} \quad$ Survey Method (GPS, etc): $\underline{\text { GPS }}$

Site Monitoring Requirements: Visual Inspections

Required Frequency (quarterly, annually?): Annual

If Monitoring Has Started, Indicate last Completion Date: $\underline{N} / \mathrm{A}$

\section{Use Restrictions}

The future use of any land related to this Corrective Action Unit (CAU), as described by the above surveyed location, is restricted from any DOE or Air Force activity that may alter or modify the containment control as approved by the state and identified in the CAU Closure Report or other CAU documentation unless appropriate concurrence is obtained in advance.

Comments: The use restriction (UR) is for uranium assumed to be present based on process knowledge. The future use of the UR area is restricted from any activity that may alter or modify the containment controls, unless appropriate concurrence is obtained in advance. Annual site inspections are required to ensure that the signs are intact and legible and that the UR is maintained. Maintenance or repair needs that are identified will be completed prior to the following inspection. Inspection results will be documented in the annual combined Nevada Test Site post-closure letter report.

Submitted By: /s/: Kevin Cabble Date: $7-2 \tau-69$ cc with copy of survey map (paper and digital (dgn) formats): CAU Files ( 2 copies) 


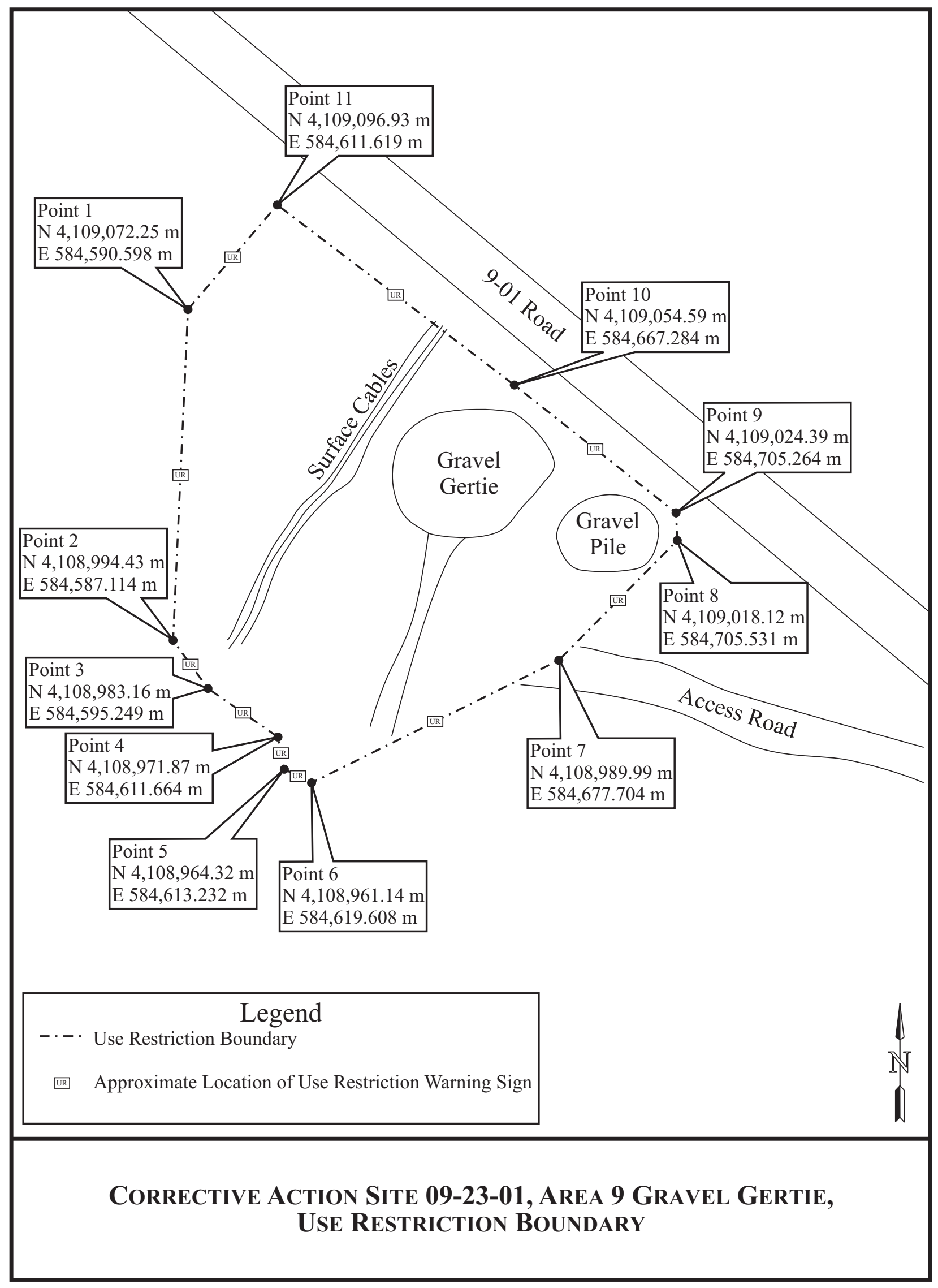


CAU 139 Closure Report

Section: Appendix E

Revision: 0

Date: July 2009

\section{APPENDIX E}

\section{SITE CLOSURE PHOTOGRAPHS}


CAU 139 Closure Report

Section: Appendix E

Revision: 0

Date: July 2009

THIS PAGE INTENTIONALLY LEFT BLANK 
PHOTOGRAPH LOG

\begin{tabular}{|c|c|c|c|}
\hline $\begin{array}{c}\text { PHOTOGRAPH } \\
\text { NUMBER }\end{array}$ & DATE & $\begin{array}{l}\text { CORRECTIVE } \\
\text { ACTION SITE }\end{array}$ & DESCRIPTION \\
\hline 1 & $12 / 08 / 2008$ & 03-35-01 & Excavation of Radiologically Impacted Soil \\
\hline 2 & $12 / 08 / 2008$ & 03-35-01 & Excavation of Radiologically Impacted Soil \\
\hline 3 & $12 / 10 / 2008$ & 04-99-01 & Excavation of Radiologically Impacted Soil \\
\hline 4 & $12 / 11 / 2008$ & 03-35-01 & Excavation of Subsurface Debris \\
\hline 5 & 01/06/2009 & 03-35-01 & Excavation of Subsurface Debris \\
\hline 6 & $01 / 06 / 2009$ & 03-35-01 & Backfilling Excavations \\
\hline 7 & 01/06/2009 & 03-35-01 & After Closure Activities \\
\hline 8 & 01/07/2009 & 04-99-01 & Backfilling Excavations \\
\hline 9 & 01/07/2009 & 04-99-01 & After Closure Activities \\
\hline 10 & $01 / 20 / 2009$ & 06-19-03 & Trench for New Water Line Location \\
\hline 11 & $01 / 20 / 2009$ & 06-19-03 & Stockpiling Soil for Cover \\
\hline 12 & $01 / 21 / 2009$ & 06-19-03 & Trench for New Water Line Location \\
\hline 13 & $01 / 26 / 2009$ & 04-99-01 & Disposal of Radiologically Impacted Soil \\
\hline 14 & 02/05/2009 & 06-19-03 & Construction of Cover \\
\hline 15 & 02/11/2009 & 06-19-03 & Construction of Cover \\
\hline 16 & 02/12/2009 & 06-19-03 & Construction of Cover \\
\hline 17 & $02 / 17 / 2009$ & 06-19-03 & Pouring Thrust Blocks for Water Line \\
\hline 18 & $02 / 24 / 2009$ & 06-19-03 & Compaction of Soil over Water Line \\
\hline 19 & 03/11/2009 & 06-19-03 & Construction of Cover \\
\hline 20 & $05 / 28 / 2009$ & 06-19-03 & Use Restriction Warning Sign \\
\hline
\end{tabular}


CAU 139 Closure Report

Section: Appendix E

Revision: 0

Date: July 2009

\section{THIS PAGE INTENTIONALLY LEFT BLANK}




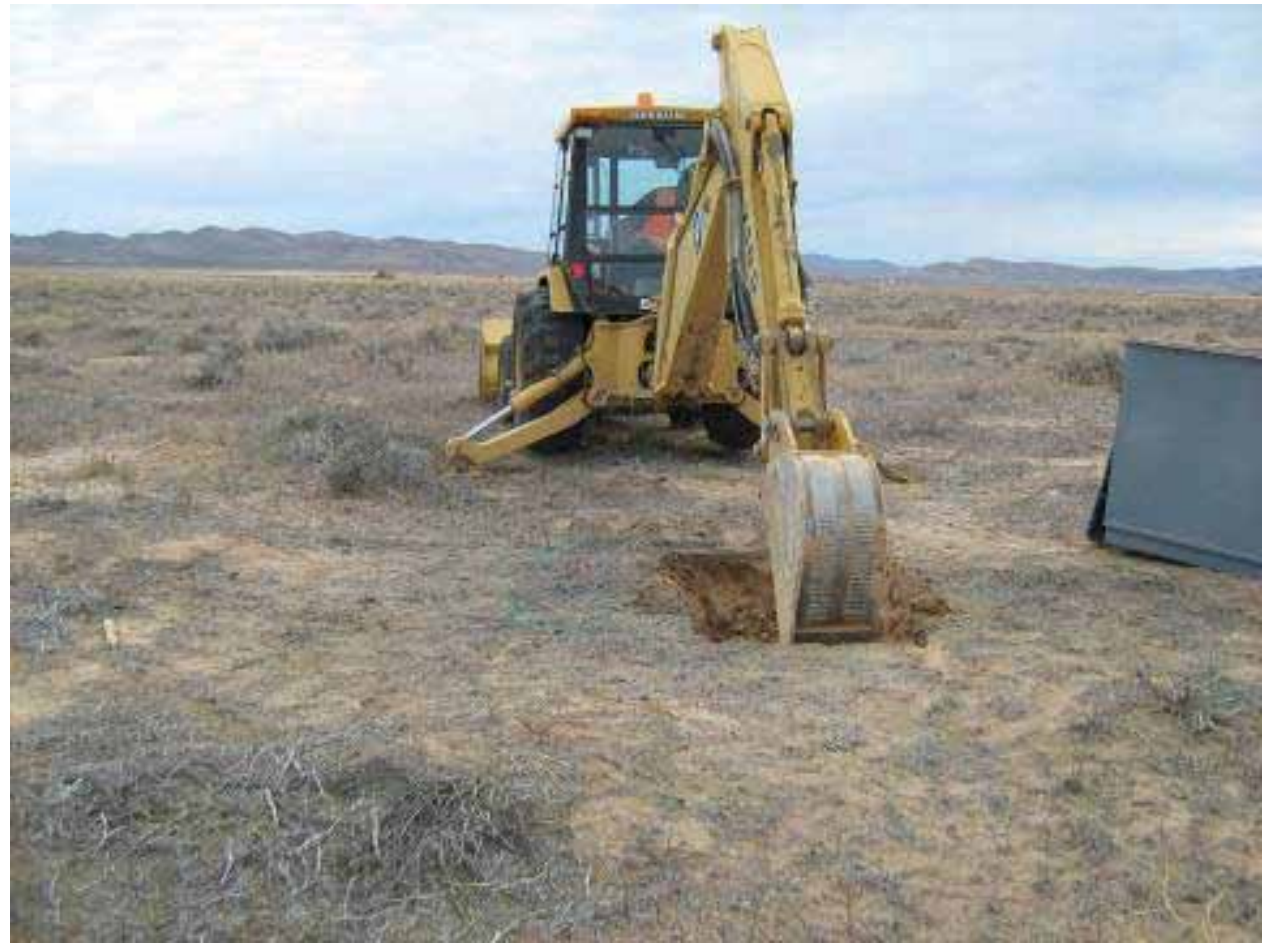

Photograph 1: CAS 03-35-01, Excavation of Radiologically Impacted Soil, 12/08/2008

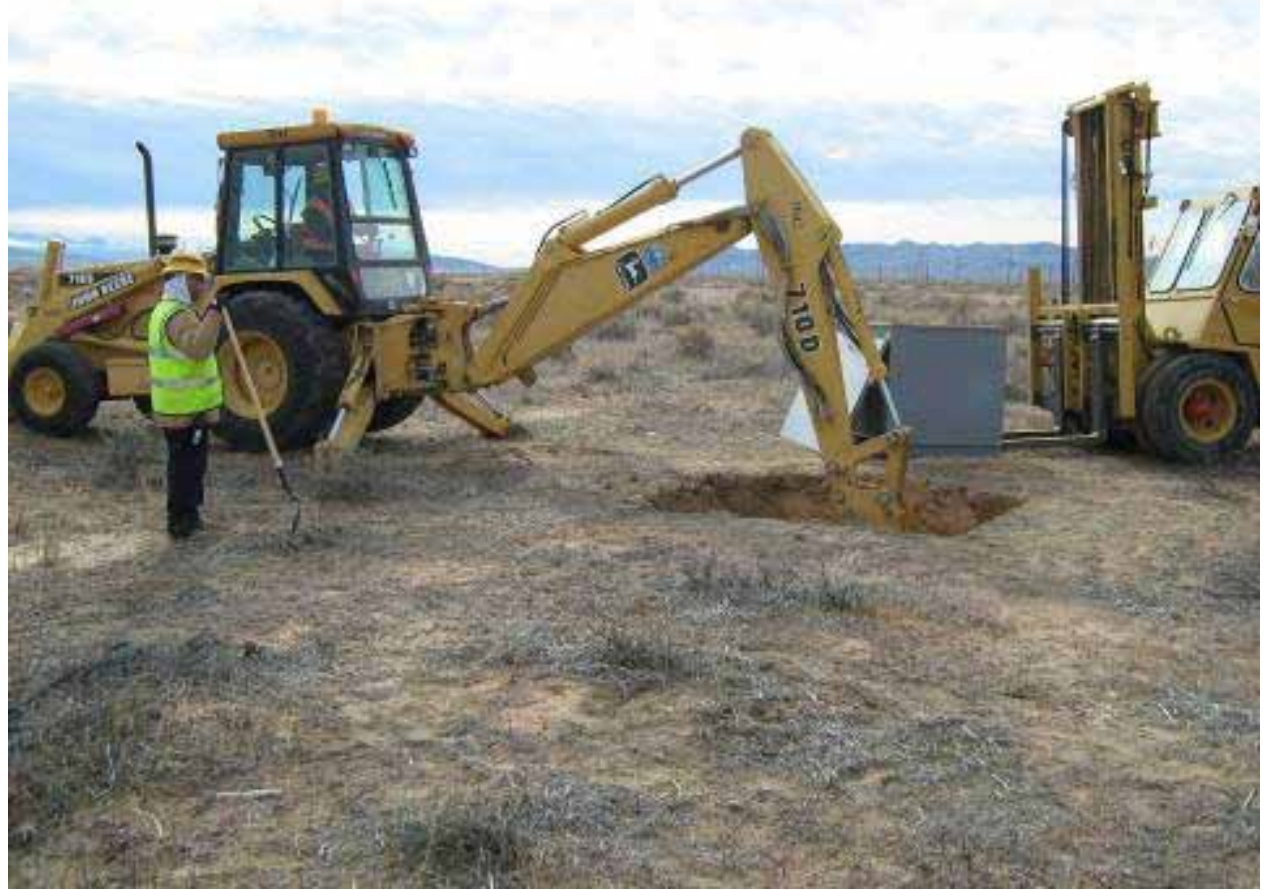

Photograph 2: CAS 03-35-01, Excavation of Radiologically Impacted Soil, 12/08/2008 


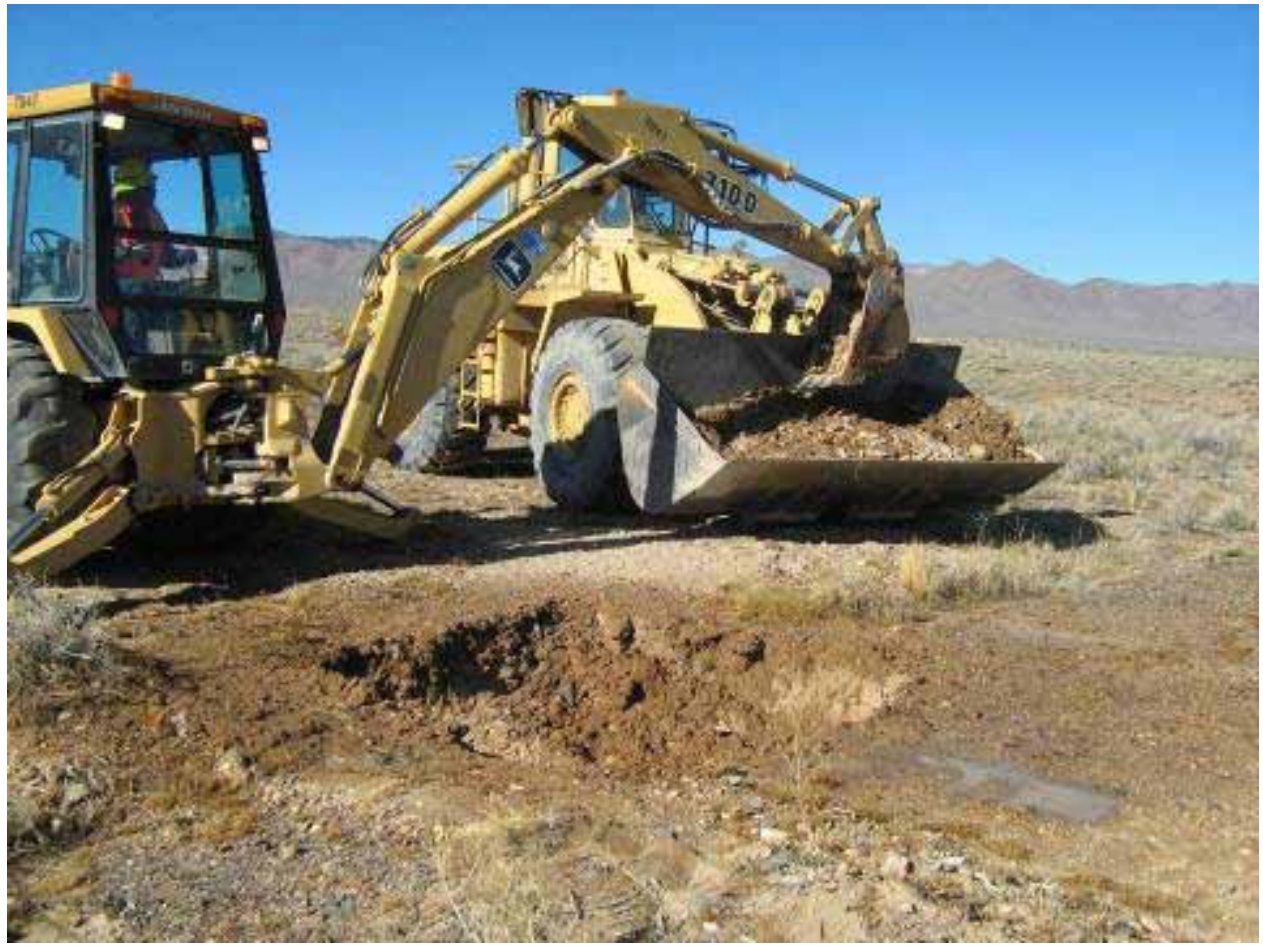

Photograph 3: CAS 04-99-01, Excavation of Radiologically Impacted Soil, 12/10/2008

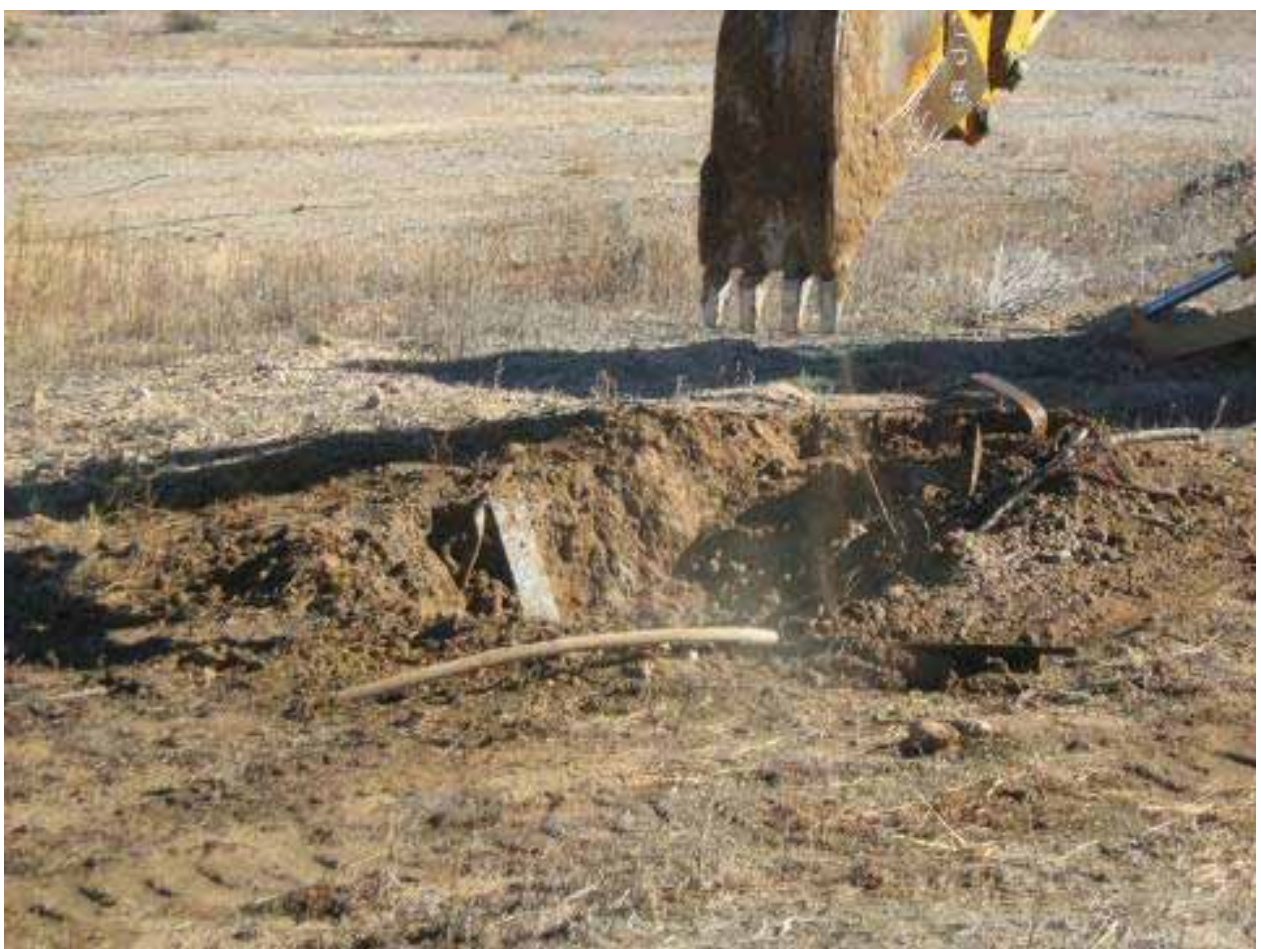

Photograph 4: CAS 03-35-01, Excavation of Subsurface Debris, 12/11/2008 


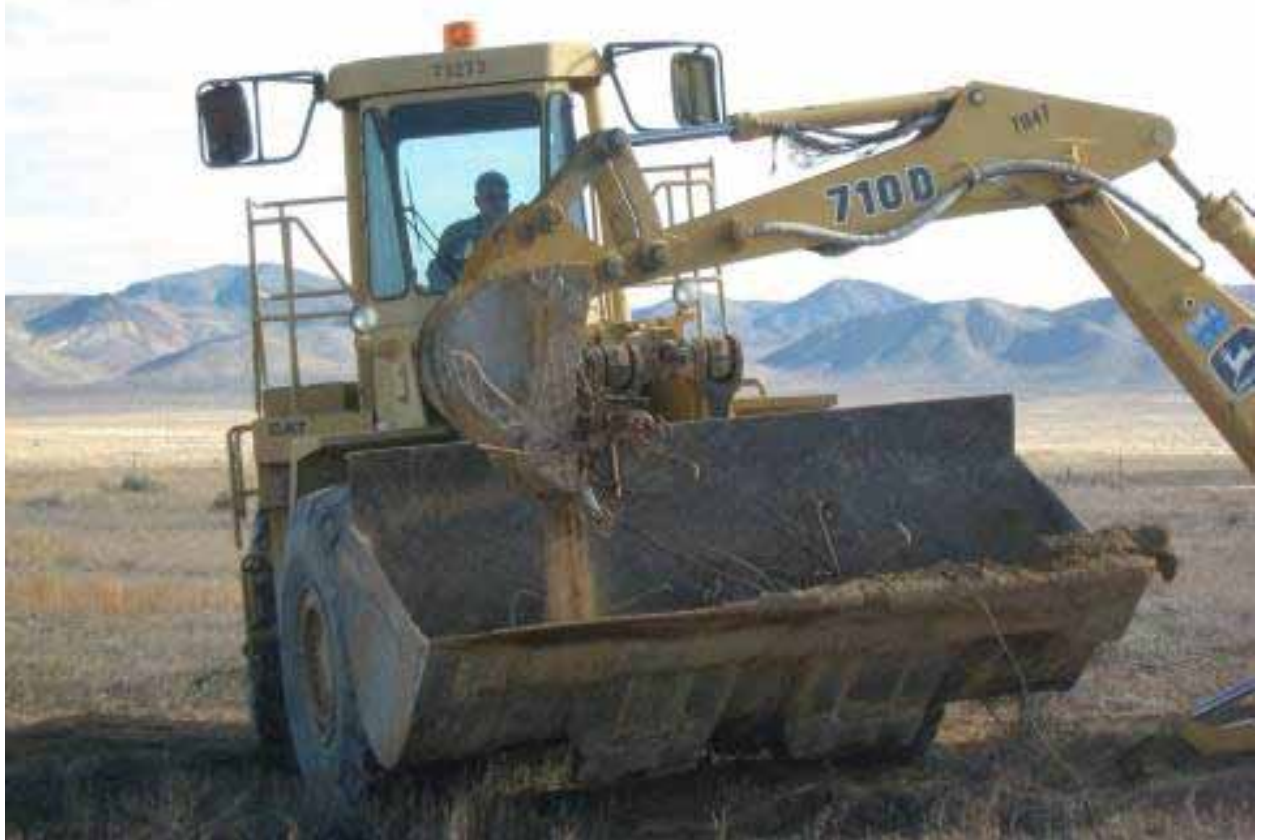

Photograph 5: CAS 03-35-01, Excavation of Subsurface Debris, 01/06/2009

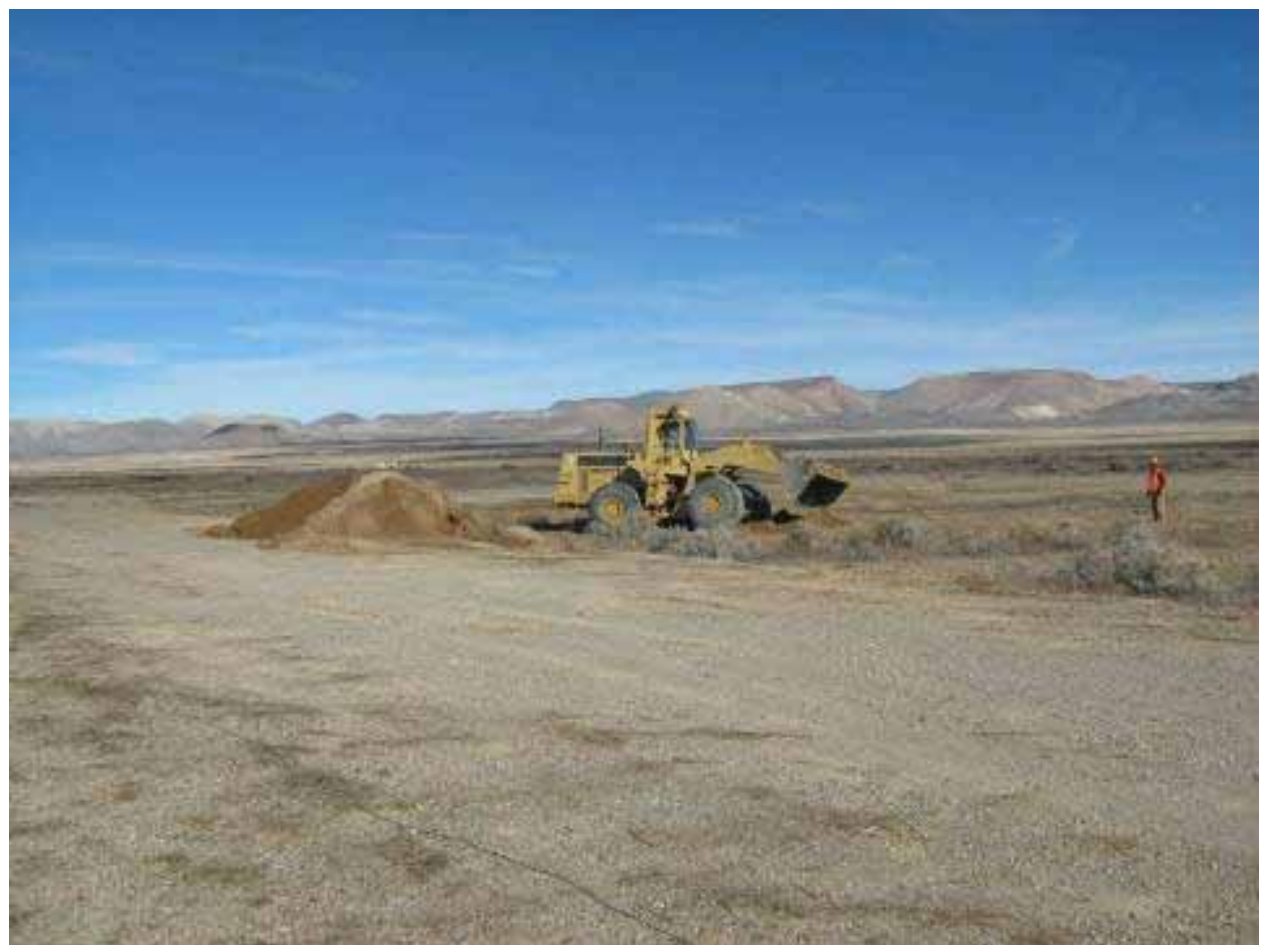

Photograph 6: CAS 03-35-01, Backfilling Excavations, 01/06/2009 


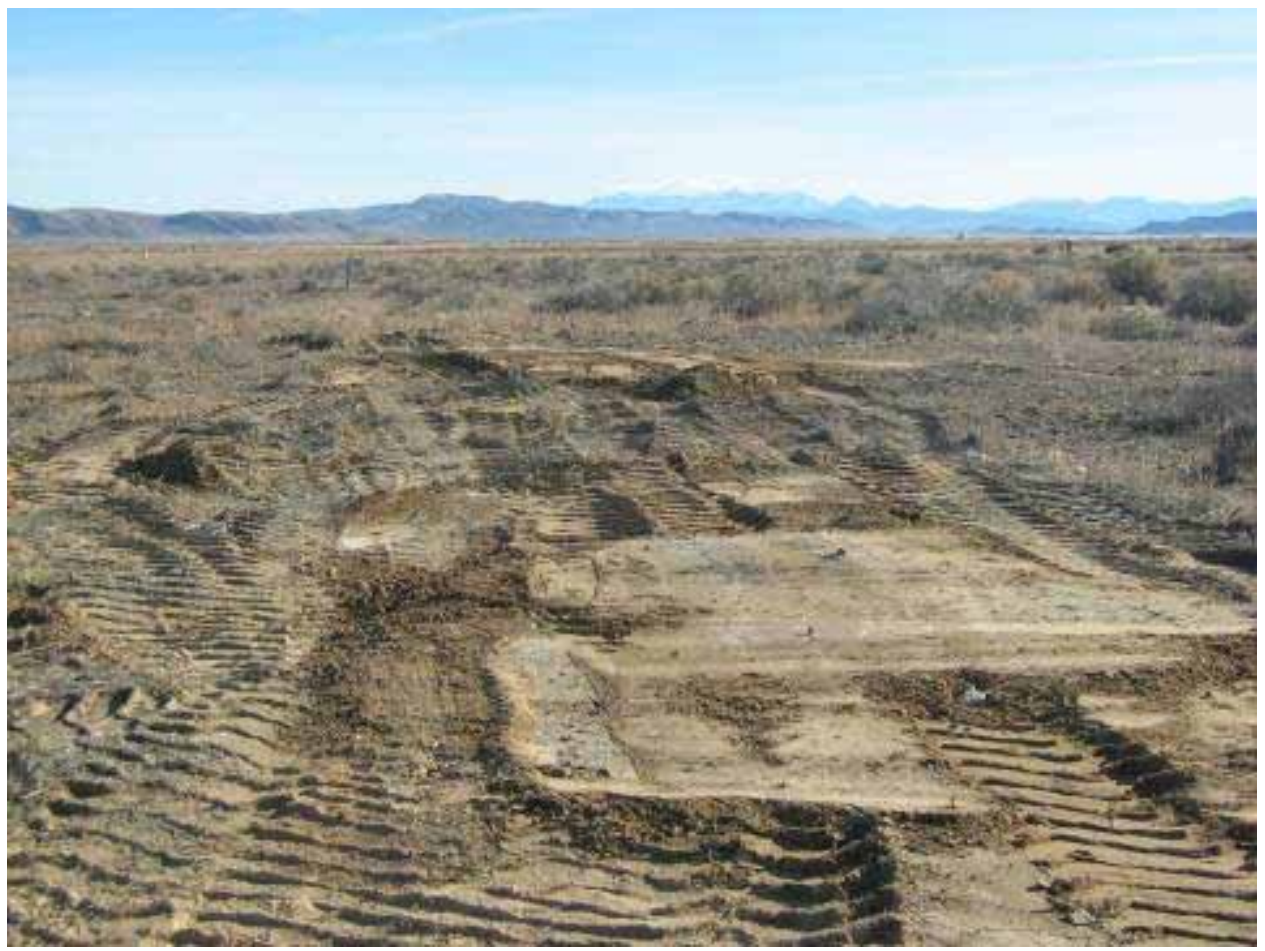

Photograph 7: CAS 03-35-01, After Closure Activities, 01/06/2009

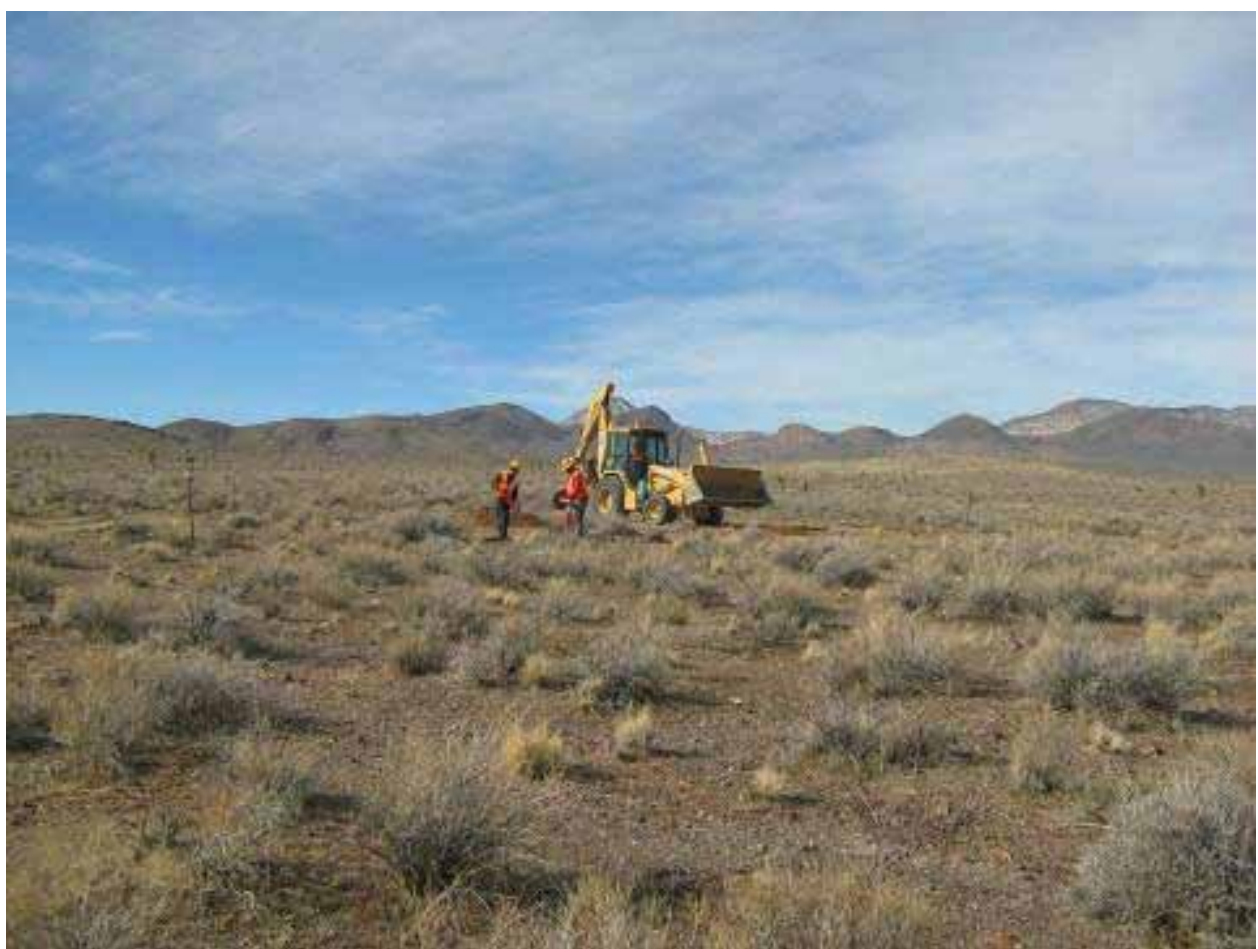

Photograph 8: CAS 04-99-01, Backfilling Excavations, 01/07/2009 


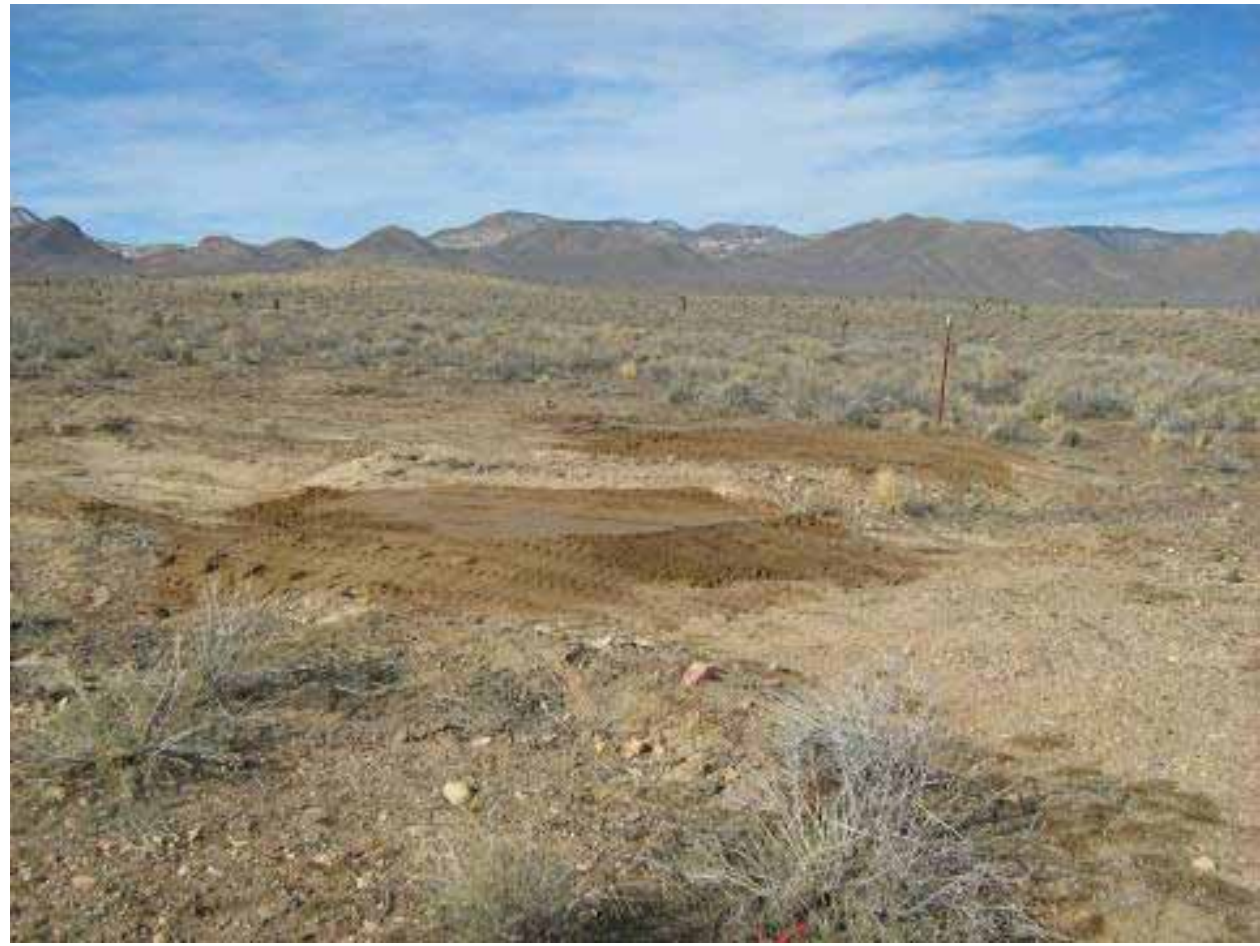

Photograph 9: CAS 04-99-01, After Closure Activities, 01/07/2009

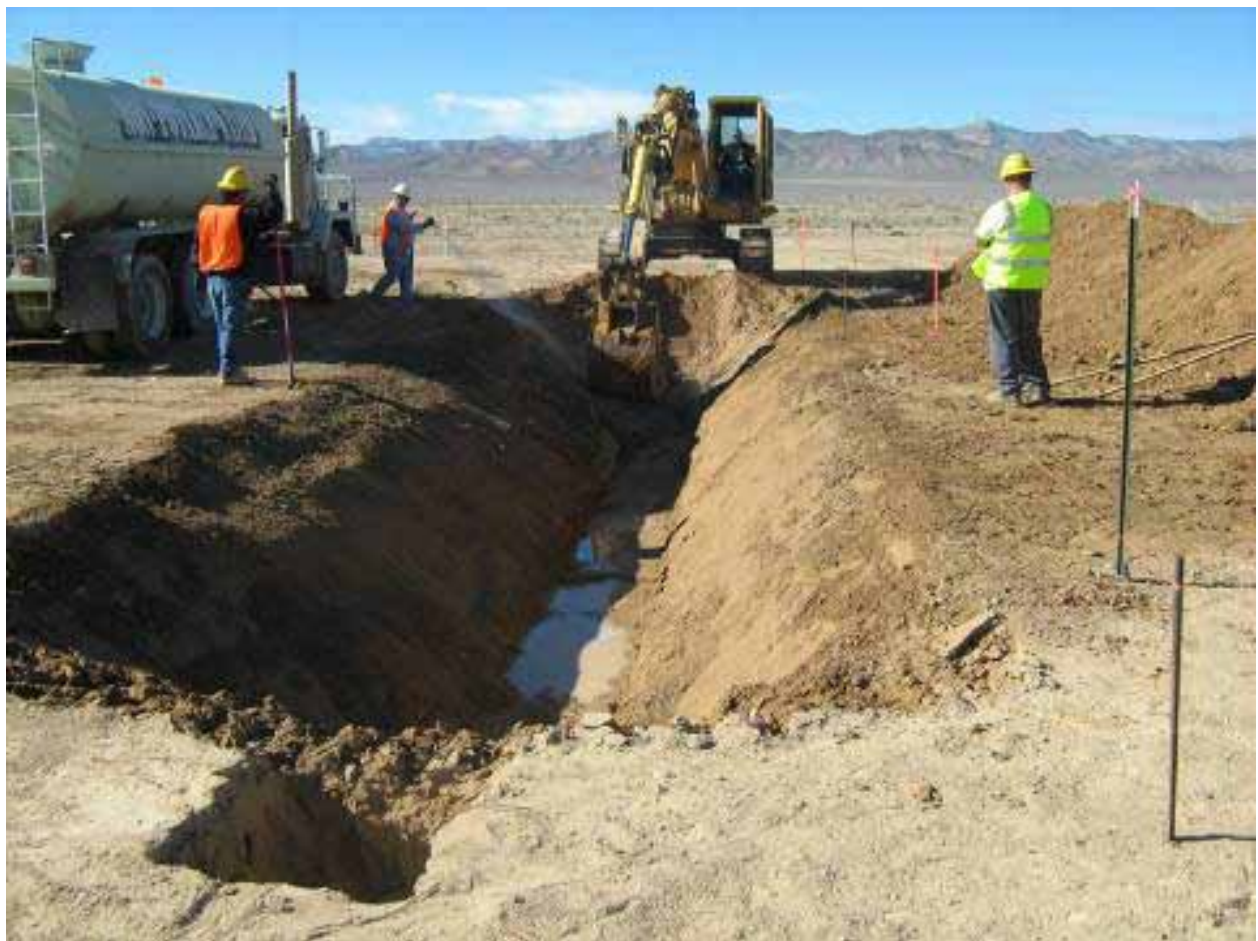

Photograph 10: CAS 06-19-03, Trench for New Water Line Location, 01/20/2009 


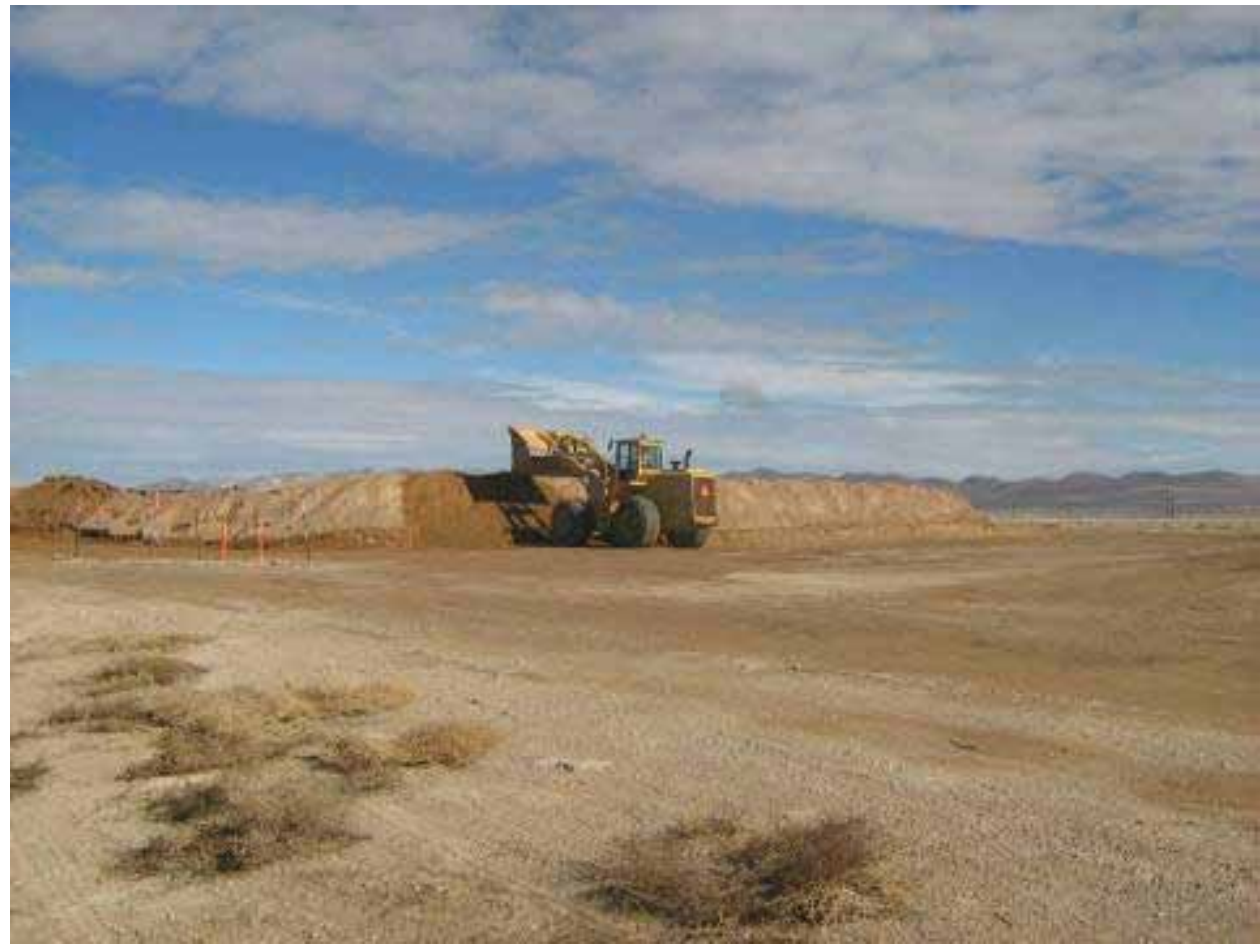

Photograph 11: CAS 06-19-03, Stockpiling Soil for Cover, 01/20/2009

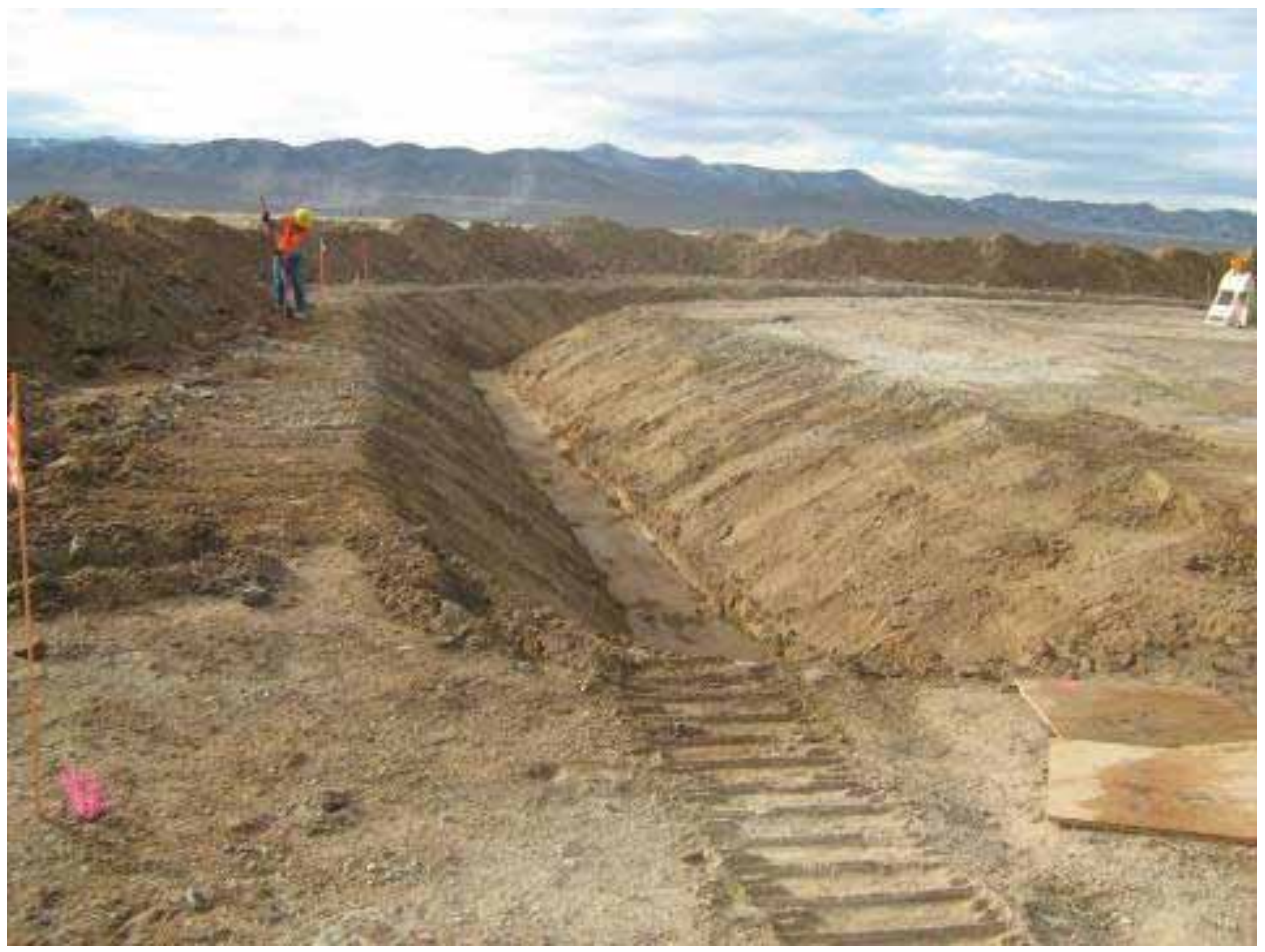

Photograph 12: CAS 06-19-03, Trench for New Water Line Location, 01/21/2009 


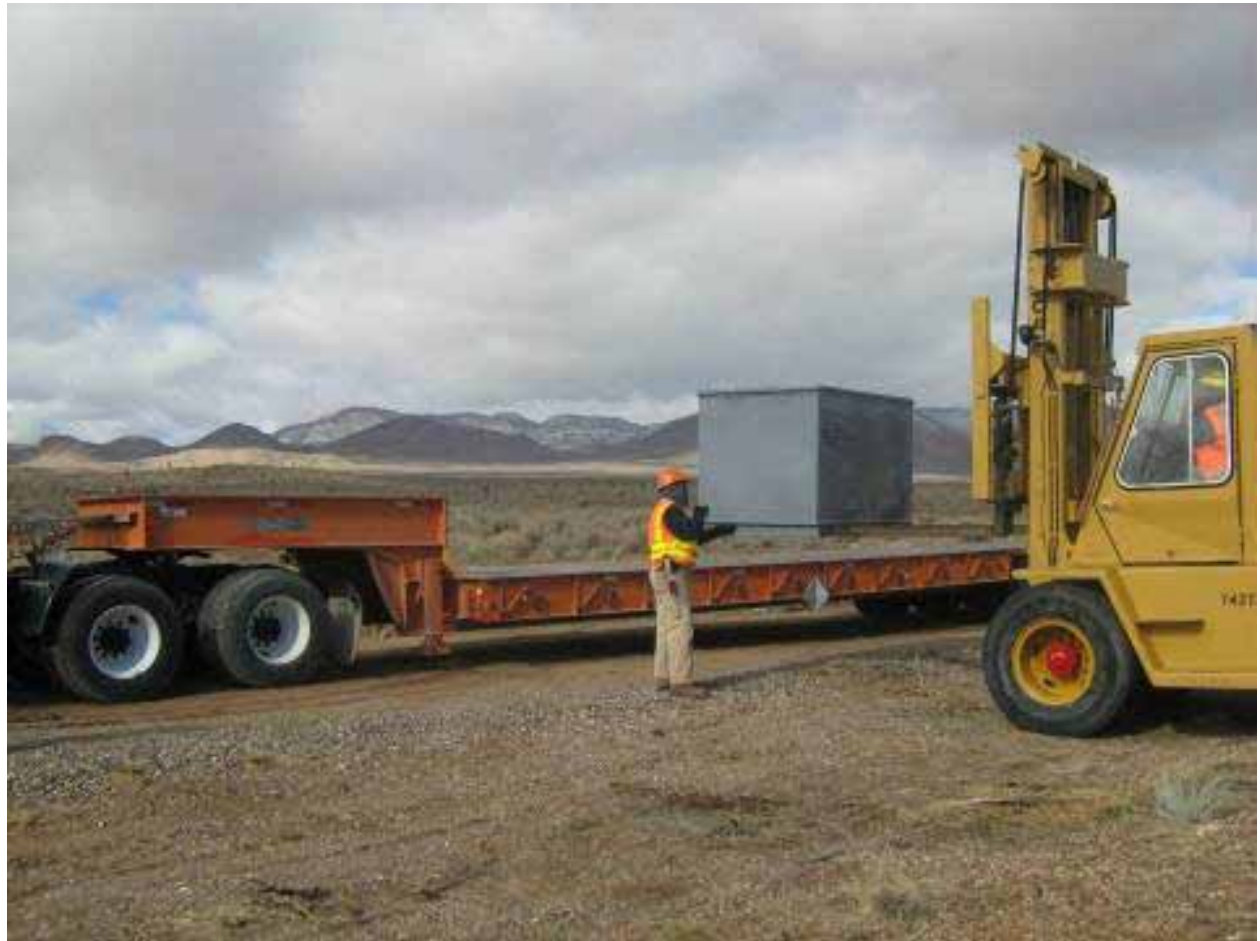

Photograph 13: CAS 04-99-01, Disposal of Radiologically Impacted Soil, 01/26/2009

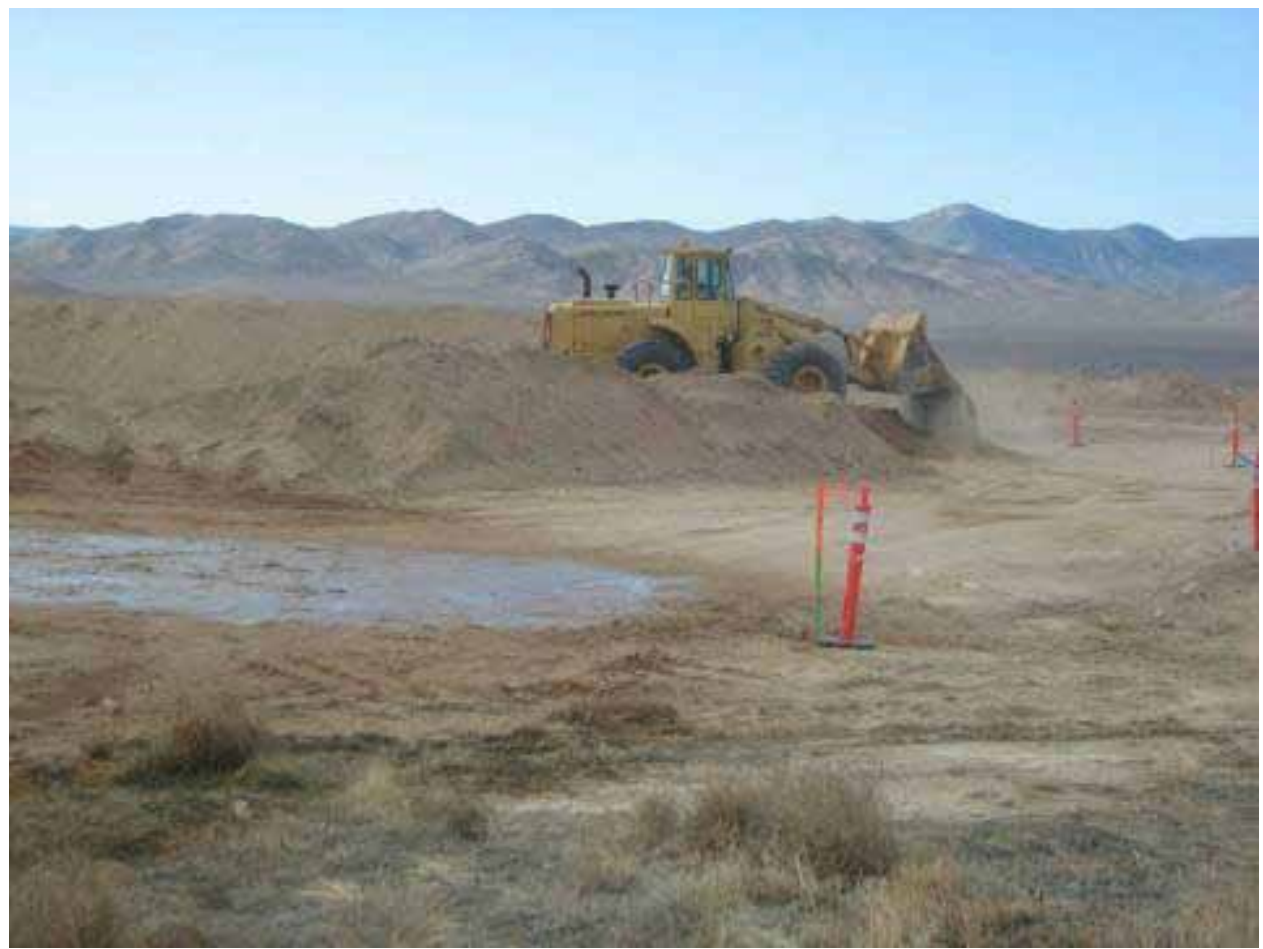

Photograph 14: CAS 06-19-03, Construction of Cover, 02/05/2009 


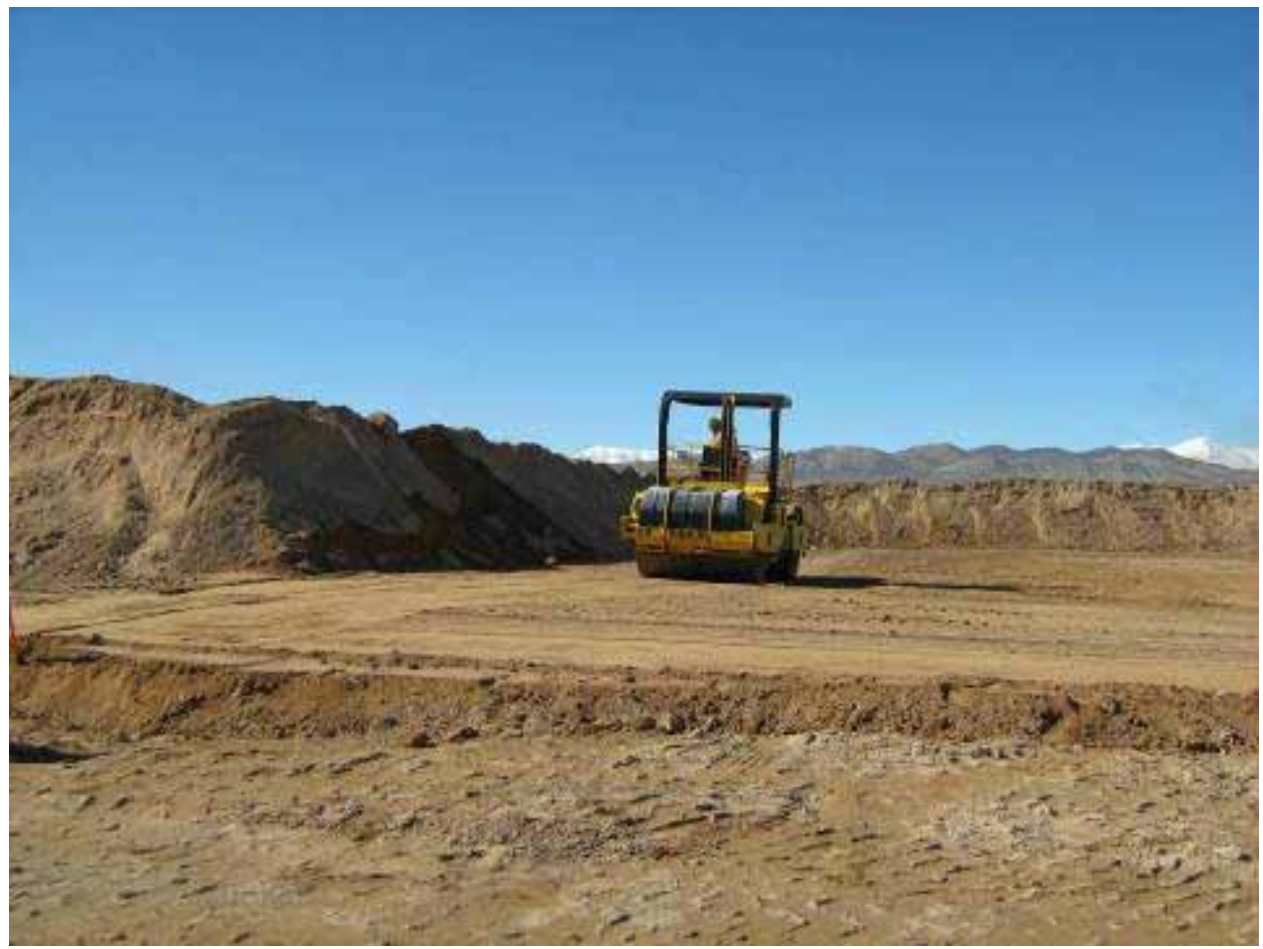

Photograph 15: CAS 06-19-03, Construction of Cover, 02/11/2009

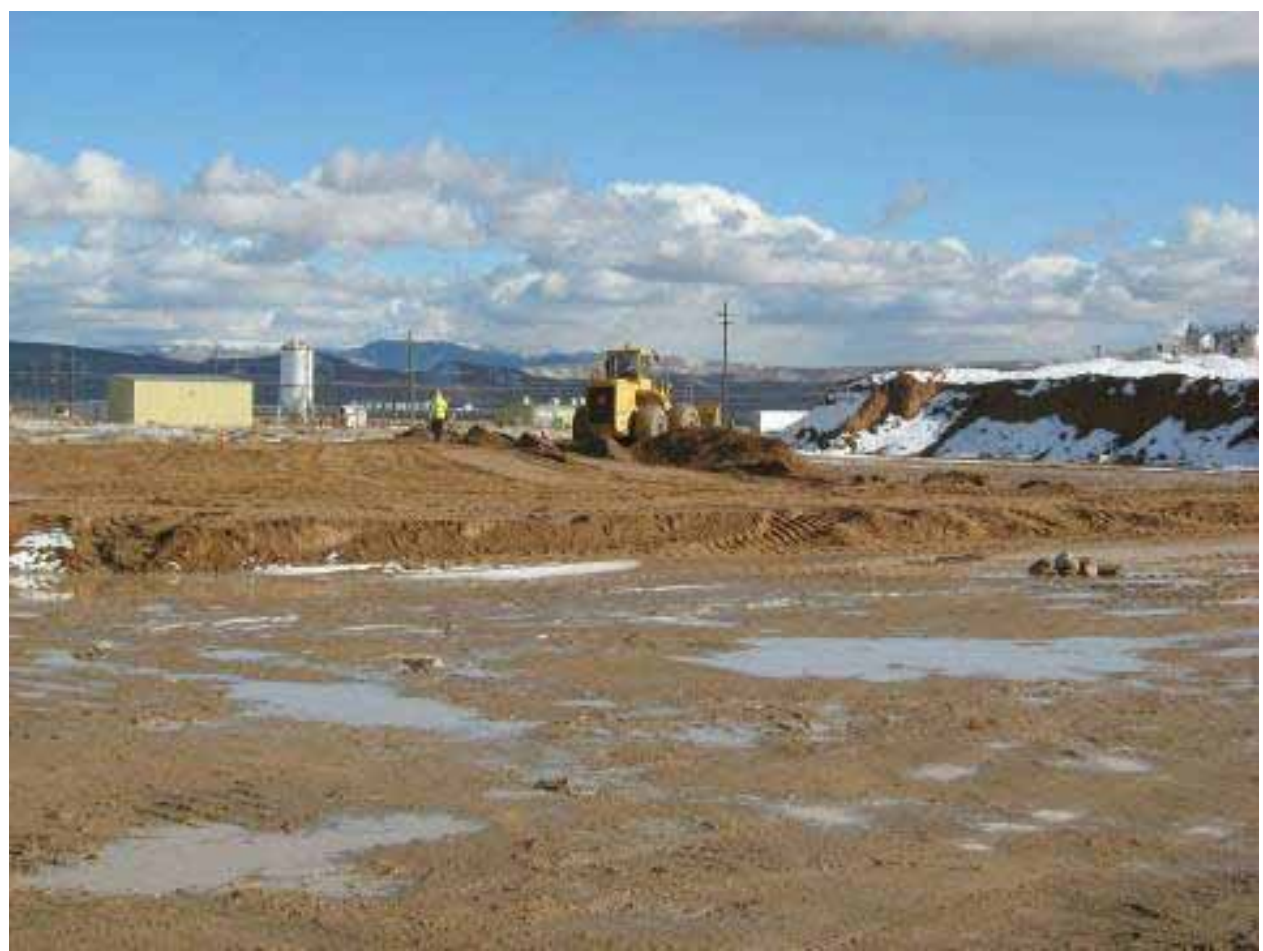

Photograph 16: CAS 06-19-03, Construction of Cover, 02/12/2009 


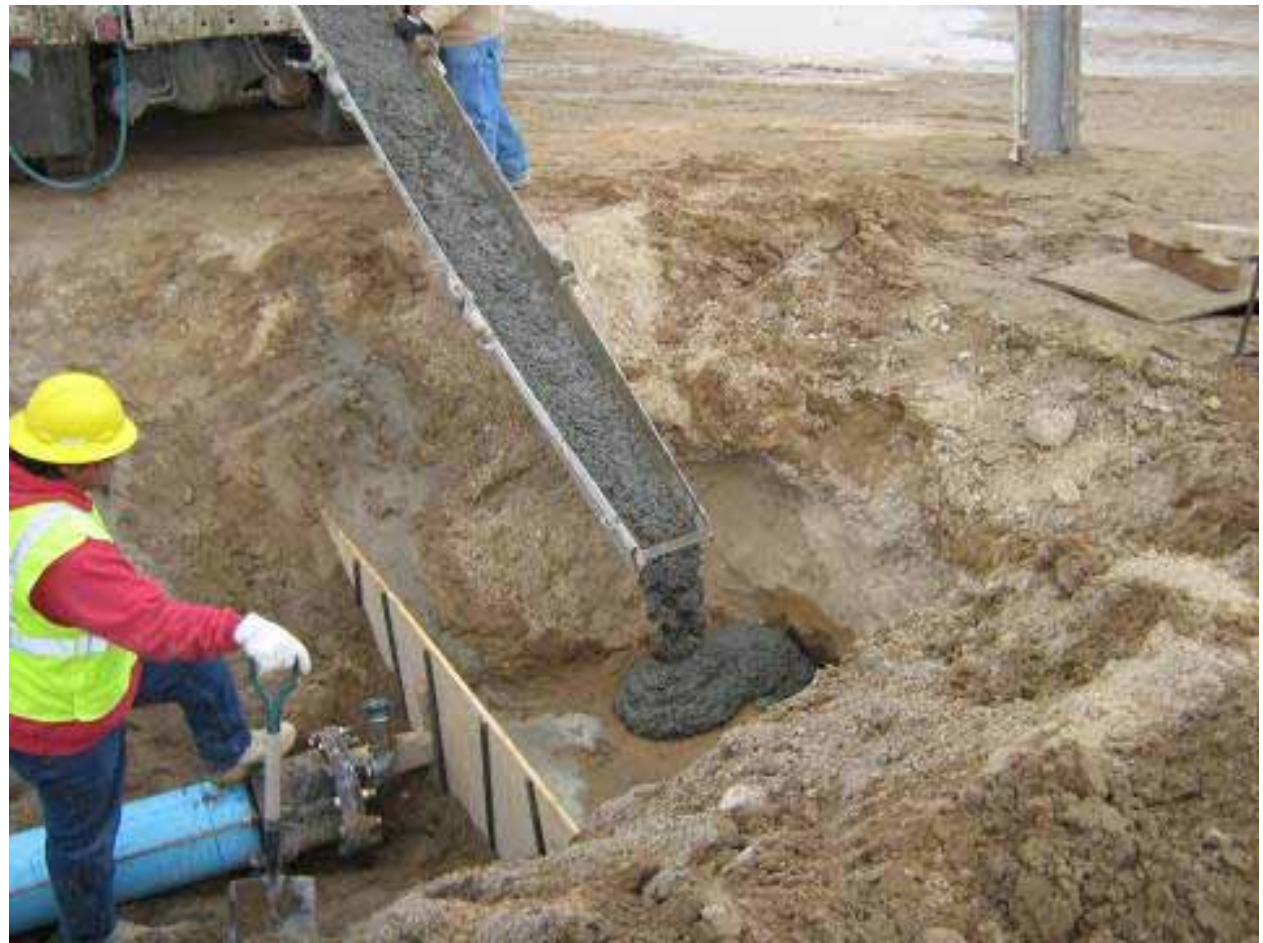

Photograph 17: CAS 06-19-03, Pouring Thrust Blocks for Water Line, 02/17/2009

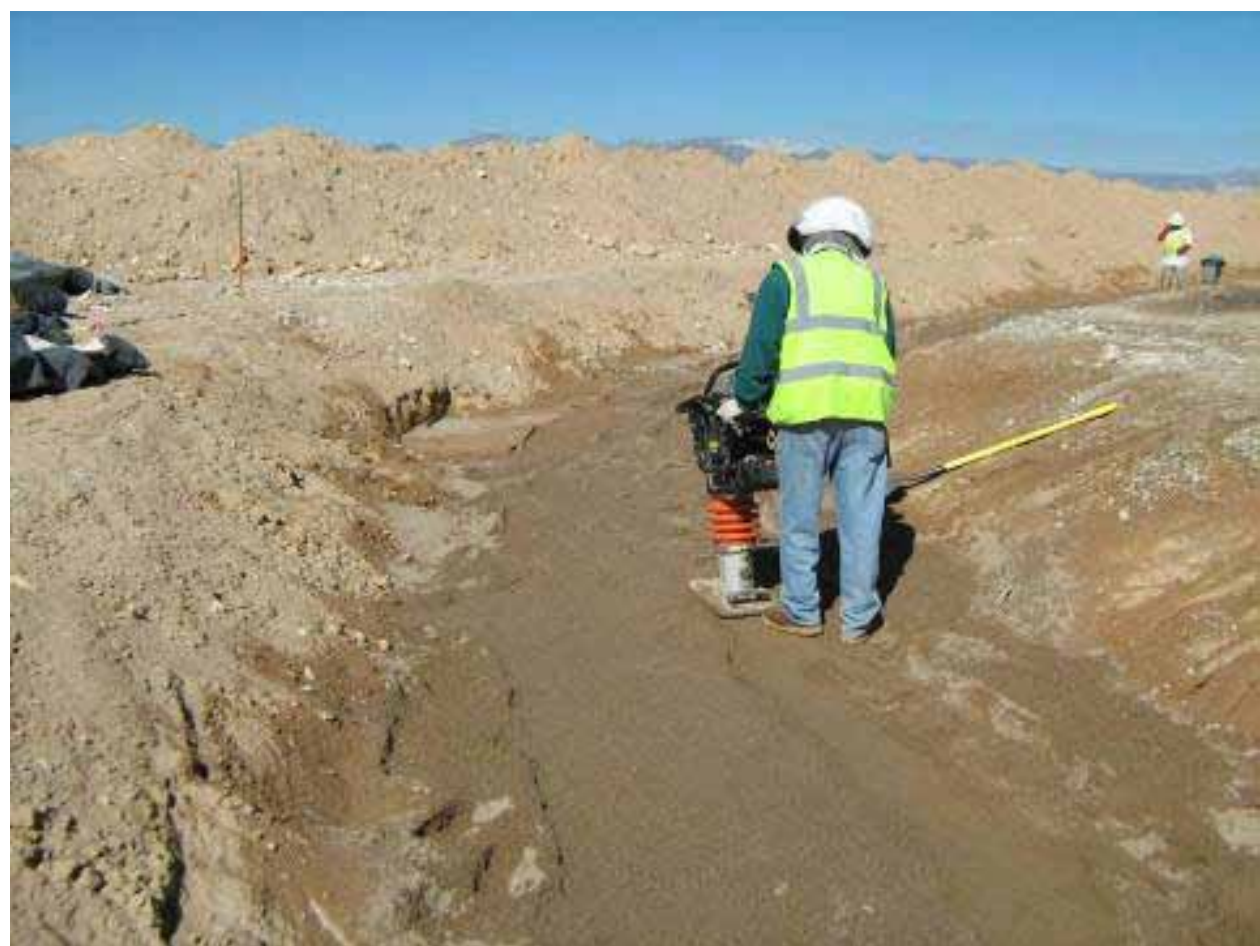

Photograph 18: CAS 06-19-03, Compaction of Soil over Water Line, 02/24/2009 


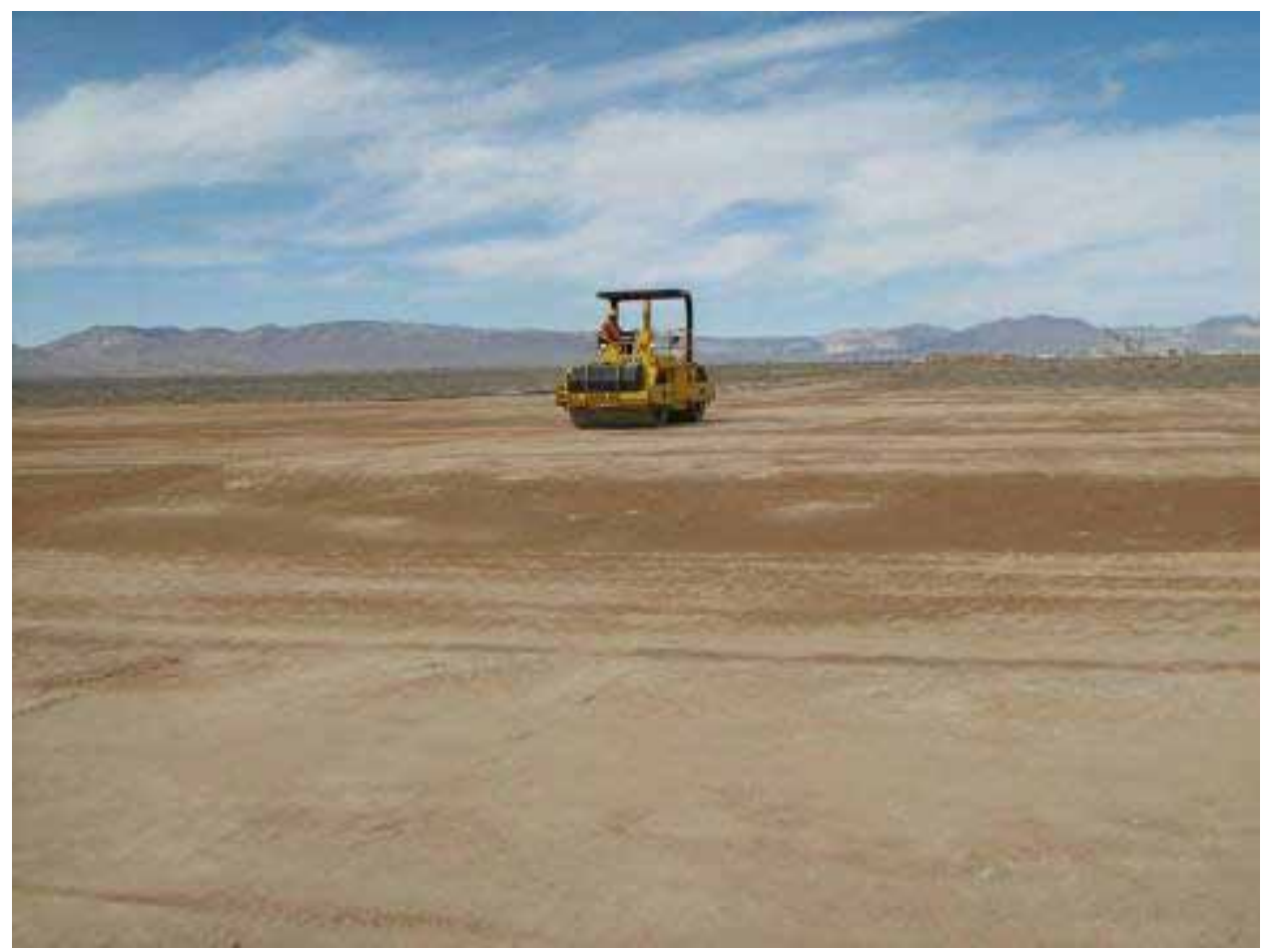

Photograph 19: CAS 06-19-03, Construction of Cover, 03/11/2009

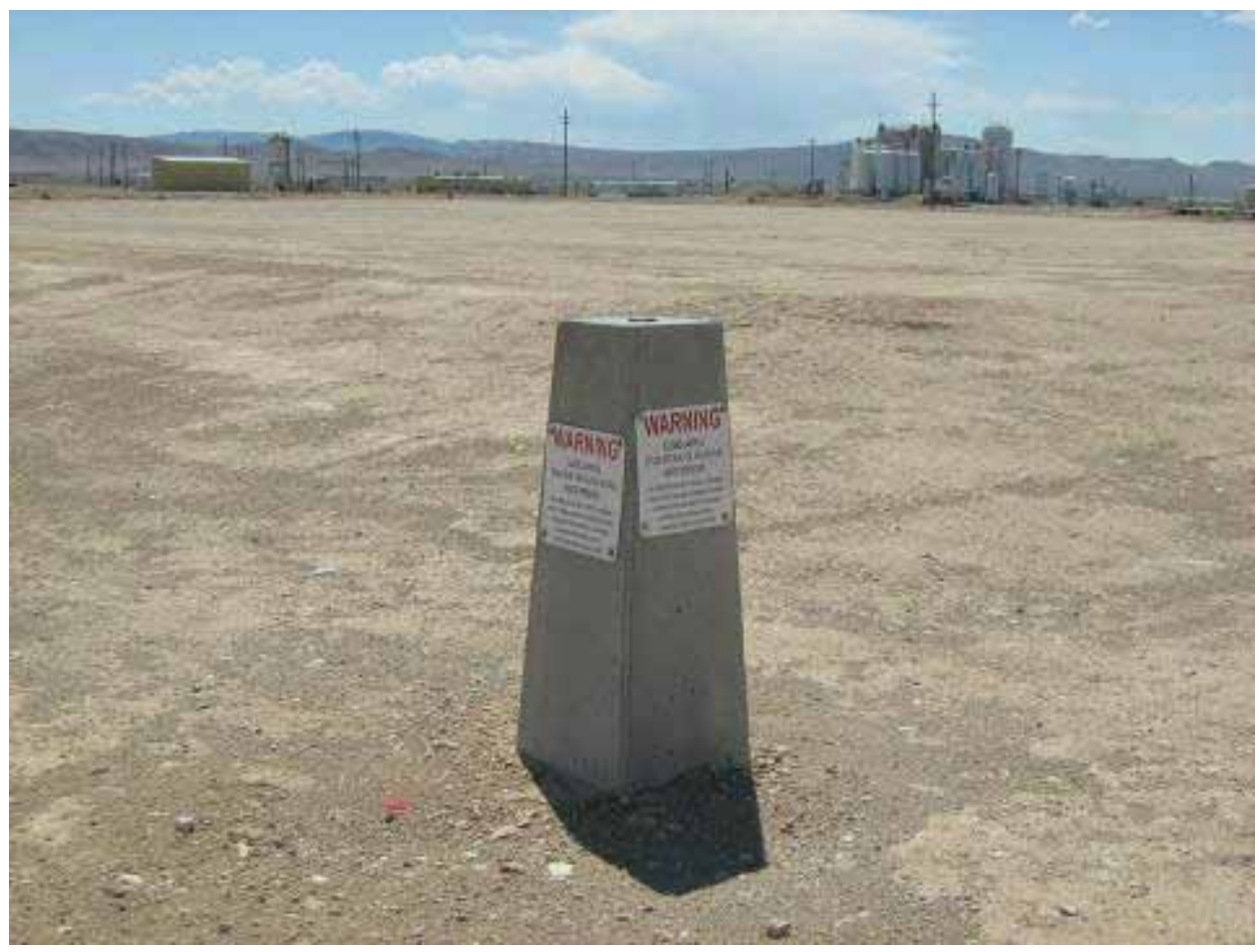

Photograph 20: CAS 06-19-03, Use Restriction Warning Sign, 05/28/2009 


\section{APPENDiX F}

\section{NeVAdA Division Of ENVIRONMENTAL PROTECTION COMMENT RESPONSE FORM}


CAU 139 Closure Report

Section: Appendix F

Revision: 0

Date: July 2009

THIS PAGE INTENTIONALLY LEFT BLANK 
Document Title: Draft Closure Report for Corrective Action Unit 139: Waste Disposal Sites, Nevada Test Site, Nevada

\section{Revision Number: 0}

Responsible NNSA/NSO ERP Federal Sub-Project Director: Kevin Cabble

No.

$1 \quad$ Appendix C - There are three pages of NTS Landfill Load Verification forms for CAS 06-19-02 at the beginning of the appendix. The waste disposal is not

mentioned within the body of the report. Please explain the source of the waste.
Document Date: June 2009

Author/Organization: NSTec

Reviewer/Organization/Phone: Jeff MacDougall/NDEP/486-2850 ext 233 Review Criteria: Full

\section{Comment Response}

The CAS number is incorrect on these forms. It has been lined out and replaced with "CAS 06-19-03." The waste identified on these load verification forms was already included in the waste volume calculations for CAS 06-19-03. 
CAU 139 Closure Report

Section: Appendix F

Revision: 0

Date: July 2009

THIS PAGE INTENTIONALLY LEFT BLANK 
CAU 139 Closure Report

Section: Library Distribution List

Revision: 0

Date: July 2009

\section{LIBRARY DISTRIBUTION LIST}


CAU 139 Closure Report

Section: Library Distribution List

Revision: 0

Date: July 2009

THIS PAGE INTENTIONALLY LEFT BLANK 


\section{LIBRARY DISTRIBUTION LIST}

U.S. Department of Energy

National Nuclear Security Administration

Nevada Site Office

Technical Library

P.O. Box 98518, M/S 505

Las Vegas, NV 89193-8518

U.S. Department of Energy

Office of Scientific and Technical Information

P.O. Box 62

Oak Ridge, TN 37831-0062

Southern Nevada Public Reading Facility

c/o Nuclear Testing Archive

P.O. Box 98521, M/S 400

Las Vegas, NV 89193-8521

Manager, Northern Nevada FFACO

Public Reading Facility

c/o Nevada State Library \& Archives

Carson City, NV 89701-4285
1 (Uncontrolled, electronic copy)

1 (Uncontrolled, electronic copy)

2 (Uncontrolled, electronic copies)

1 (Uncontrolled, electronic copy) 
CAU 139 Closure Report

Section: Library Distribution List

Revision: 0

Date: July 2009

THIS PAGE INTENTIONALLY LEFT BLANK 